\title{
What is Digital Labour? What is Digital Work? What's their Difference? And why do these Questions Matter for Under- standing Social Media?
}

\author{
Christian Fuchs* and Sebastian Sevignani**
}

\author{
*University of Westminster, UK; \\ christian.fuchs@uti.at,www.fuchs.uti.at \\ **Unified Theory of Information Research Group (UTI), Austria; \\ sebastian.sevignani@uti.at,www.sevignani.uti.at
}

\begin{abstract}
This paper deals with the questions: What is digital labour? What is digital work? Based on Marx's theory, we distinguish between work and labour as anthropological and historical forms of human activity. The notion of alienated labour is grounded in a general model of the work process that is conceptualized based on a dialectic of subject and object in the economy that we present in the form of a model, the Hegelian-Marxist dialectical triangle of the work process. Various aspects of a Marxist theory of work and labour, such as the notions of abstract and concrete labour, double-free labour, productive labour, the collective worker and general work are presented. Labour is based on a fourfold alienation of the human being. After these concepts are introduced, they are used for discussing the notions of digital labour and digital work. The presentation is on the one hand general and on the other hand uses Facebook as a concrete case for explaining how digital labour functions. Digital work is the organisation of human experiences with the help of the human brain, digital media and speech in such a way that new products are created. Digital labour is the valorisation dimension of digital work. We conclude that we require the transformation of digital labour into digital work, a true social media revolution that makes "social media" truly and fully social. We also argue why in our view work is not the same as labour by discussing the concept of playful work and pointing out limits of concepts such as antiwork, postwork and zerowork.
\end{abstract}

Keywords: Digital Labour, Facebook, Social Media, Karl Marx, Political Economy of the Media and Communication

\section{Introduction}

Digital labour is a concept that has become a crucial foundation of discussions within the realm of the political economy of the Internet (see Burston, Dyer-Witheford and Hearn 2010; Fuchs and Dyer-Witheford 2013; Scholz 2012). The basic argument in this debate is that the dominant capital accumulation model of contemporary corporate Internet platforms is based on the exploitation of users' unpaid labour, who engage in the creation of content and the use of blogs, social networking sites, wikis, microblogs, content sharing sites for fun and in these activities create value that is at the heart of profit generation (Fuchs 2010b). Online activity creates content, social networks and relations, location data, browsing data, data about likes and preferences, etc. This online activity is fun and work at the same time - play labour. Play labour (playbour) creates a data commodity that is sold to advertising clients as a commodity. They thereby obtain the possibility of presenting advertisements that are targeted to users' interests and online behaviour. Targeted advertising is at the heart of the capital accumulation model of many corporate social media platforms. It is legally enabled by terms of use and privacy policies. In the digital labour debate, the application and development of the Marxian labour theory of value and Marxist labour theories of advertising (Smythe 1977, Smythe 1981, Jhally and Livant 1986/2006) has played an important role. Dallas Smythe's Marxist political economy of the media and communication has in this context been revived and further developed (for an overview see: Fuchs 2012a, 2014). A debate 
about the use of Marx's theory and the Marxist labour theory of value has emerged in this context (see Fuchs 2010, Arvidsson and Colleoni 2012, Fuchs 2012b).

Nicholas Garnham asserted in 1990 that "the bibliography on the producers of culture is scandalously empty" (Garnham 1990,12) and that there is a focus on media barons. Ten years later, he saw this problem as persisting: "The problem of media producers has been neglected in recent media and cultural studies - indeed in social theory generally - because of the general linguistic turn and the supposed death of the author that has accompanied it. If the author does not exist or has no intentional power, why study her or him" (Garnham 2000, $84)$ ? Again ten years later, Vincent Mosco $(2011,230)$ argued that "labour remains the blind spot of communication and cultural studies" and that therefore "labour needs to be placed high on the agenda or projects for the renewal of cultural studies". This paper wants to contribute to illuminating the labour blindspot of Media and Communication Studies.

A question that has thus not been given much focus in the digital labour debate is how to best define digital labour. This article makes a contribution to finding answers. For doing so, it is necessary to engage with two related questions: What is labour? What is work? If answers to these questions can be given, then one can based on them think about how to define digital labour/work. This paper is structured in such a way that we first give a systematic overview of Marx's discussion of the terms labour and work (section 2), apply these terms to the realm of digital media (section 3) and discuss why we are differentiating the work concept from the labour concept, think that a general and alternative meaning can be given to it and why we are critical of concepts such as antiwork, postwork and zerowork (section 4).

We use Marxist political economy as our theoretical approach. This means that we ground the notions of work and labour in a systematic reading of Karl Marx's works. But why should one use Karl Marx's theory for better understanding what labour and work are and not any other theory? Aristotle made a distinction between poísesis (the creation of works from nature) and praxis (self-determined action). This philosophical distinction certainly reflects the class structures of ancient Greek society at the time of Aristotle, where slave work (poíesis) enabled the idle activity, politics and philosophical thinking of Greek citizens (praxis, theoría). In the philosophy of Christian religion, work was seen as a virtue, as expressed in Paulus' ethics of labour: "The one who is unwilling to work shall not eat" ( 2 Thessalonians $3^{1}$ ). Thomas Aquinas took up these ethics of labour in his concept of the vita activa, but added a dual pole, the vita contemplativa, as religious element. In protestant ethics, the dualism between vita activa and vita contemplativa was challenged by Martin Luther and others, who saw labour itself as a religious practice and the vita contemplativa not as a higher religious form of existence detached from labour. John Locke considered labour as unpleasant necessity that is opposed to art and thought and argued that the poor should be forced to work. For Adam Smith, the poverty of labour and the wealth of capital are connected; they are for him not God-given as assumed in earlier Christian philosophy, but a social relation that is a necessary condition for progress. Hegel described work in the context of an estate-based society, in which peasants, citizens and civil servants have different forms of work that are structured in the form of a hierarchy of recognition and a division of labour. In contrast to this conception, in which the modern class relation between capitalists and workers is invisible, Hegel also described the dialectic of master and slave that reflects the contours of capitalist class relations.

In Christian philosophy, the existence of alienated labour and class relations was always considered as being God-given. In classical political economy, the idea of the God-given nature of toil and poverty was given up and class relations were conceived as social relations. This relation was however considered as being necessary for progress, its potential sublation was not seen as a historical potential enabled by the development of the productive forces. Classical political economy ignored to clarify its claim that the current state of the capitalist mode of production is eternal. As a consequence, it saw the form of labour that exist in capitalism that is characterised by a division of labour, private property and class relations, as eternal and naturalised it thereby. In contrast, Marx was critical of such views. Therefore

\footnotetext{
${ }^{1}$ http://www.biblegateway.com/passage/?search=2+Thessalonians+3\%3A1-
} 
his approach is a critique of political economy and not only a contribution to political economy. Marx was the first author who described the historical character of work as crucial point for understanding political economy (Marx 1867, 131f). When discussing what work and labour are, Marx offers the most thorough analysis that is available. In encyclopaedias and dictionaries of economics, entries such as labour, labour power, labour process or labour theory are therefore often predominantly associated with Marx and Marxist theory (see e.g. the corresponding entries in Eatwell, Milgate and Newman 1987).

\section{Marx on Work and Labour}

We distinguish three levels of Marx's works, on which we analyse how he conceives the concepts of work and labour: society in general (2.1), class societies and capitalism (2.2), communism (2.3).

\subsection{Work and Labour in Society}

Marx gave an anthropological characterisation of work. In the German Ideology, Marx and Engels $(1845 / 46,37)$ argue that work is a conscious productive activity that transforms and organises nature so that humans "produce their means of subsistence" in order to satisfy human needs, which constitutes "the production of material life itself" (Marx and Engels $1845 / 46,47)$. "Real labour is purposeful activity aimed at the creation of a use value, at the appropriation of natural material in a manner which corresponds to particular needs" (Marx 1861-63). Humans are producing beings that produce both physical resources and ideas. For organising production and society, humans enter "definite social and political relations" (Marx and Engels 1845/46, 41). In the Introduction to the Critique of Political Economy (Marx and Engels 1845/46, 1-23), Marx explains that the economy involves in all societies processes of production, distribution and consumption and that work is an activity embedded into this system.

In Capital, Volume 1, Marx begins the discussion of capitalism with an exposition of the commodity form. After defining two aspects of a commodity, namely use-value and exchange-value, he switches from the analysis of objective structures in section 1.1 to the analysis of subjectivity, i.e. the world of work, in section 1.2 "The dual character of the labour embodied in commodities". In this chapter, Marx argues that work has both an anthropological and a historical character: In all societies, it is an activity that produces goods that satisfy human needs. In concrete societies, work takes on specific historical characteristics, such as slave work, house work, wage work, etc. "As useful activity directed to the appropriation of natural factors in one form or another, labour is a natural condition of human existence, a condition of material interchange between man and nature, quite independent of the form of society. On the other hand, the labour which posits exchange-value is a specific social form of labour" (Marx 1859).

A basic question that we have to pose when discussing the concepts of work and labour is if work/labour is an essence of human society or a specific expression of economic domination. Let us for this purpose compare two quotes of Marx, in which he talks about work and that show the importance of clearly defining the anthropological and historical dimension of work:

- "Labour, then, as the creator, of use-values, is useful labour, is a condition of human existence which is independent of all forms of society; it is a eternal natural necessity which mediates the metabolism between man and nature, and therefore human life itself" (Marx $1867,133)^{2}$.

\footnotetext{
2 "Als Bildnerin von Gebrauchswerten, als nützliche Arbeit, ist die Arbeit daher eine von allen Gesellschaftsformen unabhängige Existenzbedingung des Menschen, ewige Naturnotwendigkeit, um den Stoffwechsel zwischen Mensch und Natur, also das menschliche Leben zu vermitteln" (MEW 23, 192).
} 
- "The realm of freedom really begins only where labour determined by necessity and external expediency ends; it lies by its very nature beyond the sphere of material production proper“3 $^{\text {“3 }}$ (Marx 1894/1991, 958-959)

In the first quotation, Marx sees work as necessary element of all societies. The second quotation is more ambiguous: It can on the one hand mean that in a communist society alienation ceases to exist and that therefore work no longer exists because it is always alienated. Or it can mean that labour as an alienated form of work comes to an end and work takes on a humane character.

In the German Ideology, Marx and Engels argue that communism abolishes the division of labour and enables the "transformation of labour into self-activity" (Marx and Engels 1845/46, 97) and that the "communist revolution [...] does away with labour" (Marx and Engels 1845/46, 60). Marx after the word "labour" (Arbeit in the German original) crossed out the words "the modern form of activity under the rule of" (Marx and Engels 1845/46, 60), which shows that he was not so sure if he should use the formulation that communism does away with Arbeit or does away with the modern form of the organisation of Arbeit. So given these different passages from various works, it is not clear if Marx thought that work/labour exists in a communist society or not. The problem is further complicated by the fact that he wrote in German, where there is one common word for work and labour - Arbeit (although there is also the term Werktätigkeit (the activity of creating works) that is a much more general concept, but tends to be hardly used in German. The term Arbeit was translated sometimes as "work" and sometimes as "labour". Engels has in a footnote to Marx's Capital pointed out that the English language allows to make a semantic differentiation: "The English language has the advantage of possessing two separate words for these two different aspects of labour. Labour which creates use-values and is qualitatively determined is called 'work' as opposed to 'labour'; labour which creates value and is only measured quantitatively is called 'labour', as opposed to 'work'" (Marx 1867, 138). In this paper, we will use this distinction for discerning digital labour from digital work.

Adopting this terminology allows avoiding confusion. Labour is a necessarily alienated form of work, in which humans do not control and own the means and results of production. It is a historic form of the organisation of work in class societies. Work in contrast is a much more general concept common to all societies. It is a process in which humans in social relations make use of technologies in order to transform nature, culture and society in such a way that goods and services are created that satisfy human needs. Given this distinction, the translation of the passage in the German Ideology, where Marx and Engels say that communism does away with labour is feasible, whereas the other cited passages should better be translated as communism enabling the transformation of work organised as labour into work as self-activity. The passage in Capital, Volume 3, is especially ambiguous (both in the German original and the English translation) and this ambiguity could best be resolved by translating the sentence the following way: The realm of freedom really begins only where labour, which is a form of work that is determined by necessity and external expediency, ends.

Raymond Williams $(1983,176-179)$ argues that the word "labour" comes from the French word labour and appeared in the English language first around 1300. It was associated with hard work, pain and trouble. In the $18^{\text {th }}$ century, it would have attained the meaning of work under capitalist conditions that stands in a class relationship with capital. The term work comes from the Old English word "weorc" and is the "most general word for doing something" (Williams 1983, 334). In capitalism the term on the one hand has according to Williams (1983, 334-337) acquired the same meaning as labour - a paid job -, but would have in contrast also kept his original broader meaning. In order to be able to differentiate the dual his-

\footnotetext{
3 "Das Reich der Freiheit beginnt in der Tat erst da, wo das Arbeiten, das durch Not und äußere Zweckmäßigkeit bestimmt ist, aufhört; es liegt also der Natur der Sache nach jenseits der Sphäre der eigentlichen materiellen Produktion" (MEW 25, 828).
} 
torical and essential character of work, it is feasible to make a semantic differentiation between labour and work.

In the Economic Manuscripts of 1861-1863, Marx (1861-1863) argues that the means of labour contain the material of labour and the means of labour. This formulation is still somewhat inept because it uses the term means of labour twice. In the Grundrisse, Marx $(1857 / 58 b, 300)$ makes clear that the labour activity, the labour material, the labour instrument and the labour product are inherently connected aspects of production. Labour is a "sublation of sublation" (Marx 1857/58a, 2224): labour is a "form-giving activity" (Marx $1857 / 58 \mathrm{~b}, 301)$ that sublates itself in the production process and sublates the material. Thereby it creates "a new objective form" (Marx 1857/58b, 301), a new product. This means that labour is a process of productive consumption: it consumes natural products and labour power and in this process creates a new product. "Labour uses up its material elements, its objects and its instruments. It consumes them, and is therefore a process of consumption. [...] Thus the product of individual consumption is the consumer himself; the result of productive consumption is a product distinct from the consumer" (Marx 1867, 290). The outcome of this process are use values (Marx 1857/58b, 301). This shows that here Marx uses the term use-value in a general anthropological sense. In Capital, Marx (1867) makes a threefold distinction between labour power, the object of labour and the instruments of labour. "The simple elements of the labour process are (1) purposeful activity, (2) the object on which that work is performed, and (3) the instruments of that work" (Marx 1867, 284).

Marx's discussion of the production process can be presented in a systematic way by using Hegel's concept of the dialectic of subject and object. Hegel (1991) has spoken of a dialectical relation of subject and object: the existence of a producing subject is based on an external objective environment that enables and constrains, i.e. conditions, human existence. Human activities can transform the external (social, cultural, economic, political, natural) environment. As a result of the interaction of subject and object, new reality is created - Hegel terms the result of this interaction subject-object. The next figure shows that Hegel's notion of subject, object, and subject-object form a dialectical triangle.

\footnotetext{
${ }^{4}$ We have provided here our own translation because the English translation of "Aufheben dieses Aufhebens" (Marx 1857/58a, 222) as "suspension of this suspension" (Marx 1857/58b, 301) does not capture the Hegeliandialectical meaning of the term Aufhebung that is correctly translated with the term sublation.
} 
Hegel, logic of the concept (third subdivision of the logic, Encyclopaedia I, $\S \S 160-244)$

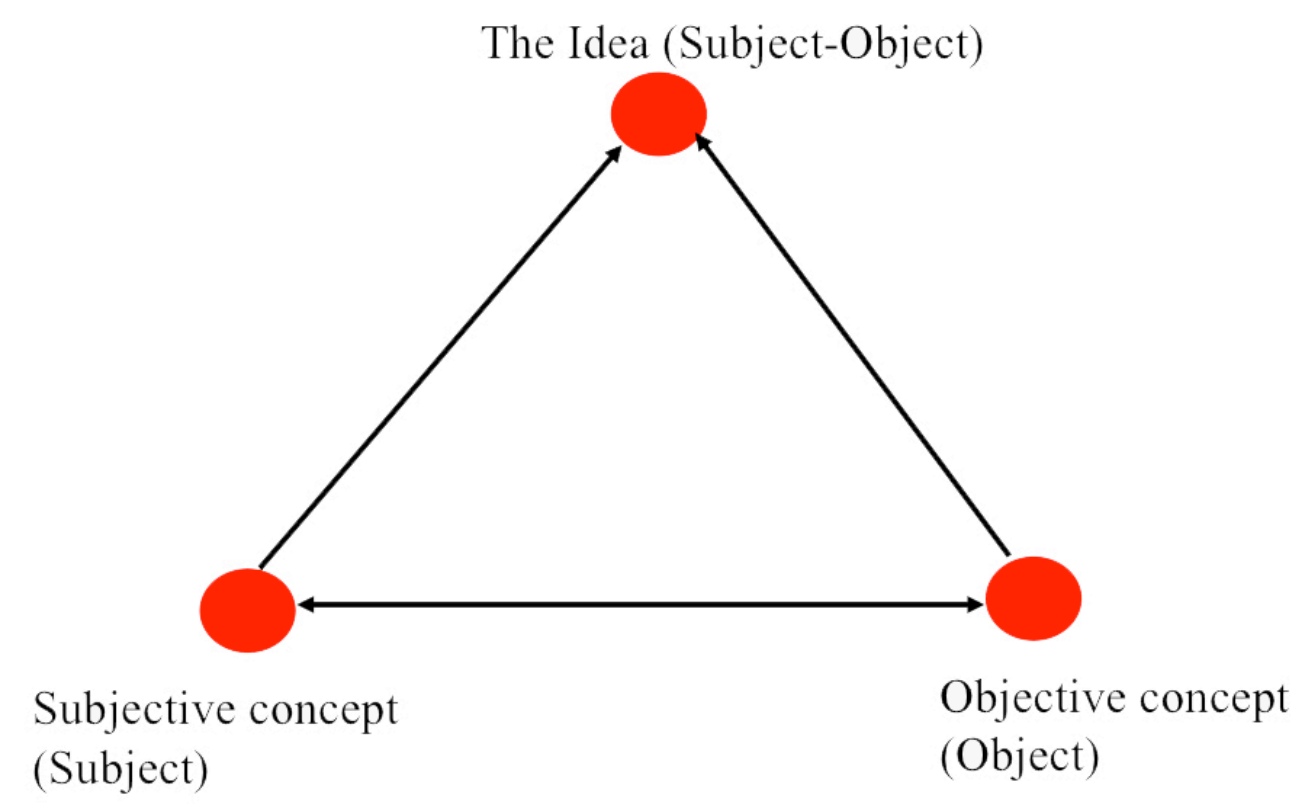

Figure 1: The dialectical triangle of subject-object-subject/object

Hegel (1991) characterizes the "subjective concept" as formal (§162), finite, determinations of the understanding, general notions (§162), "altogether concrete" (§164). He defines "the subject" $(\S 164)$ as "the posited unseparatedness of the moments in their distinction" (§164). Hegel characterizes objectivity as totality (\$193), "external objectivity" (§208), "external to an other" (§193), "the objective world in general" (§193) that "falls apart inwardly into [an] undetermined manifoldness", "immediate being" (\$194), "indifference vis-à-vis the distinction" (§194), "realisation of purpose" (§194), "purposive activity" (§206), "the means" (§206). The Idea is "the Subject-Object" ( $\$ 162)$, absolute Truth $(\S 162)$, the unity of the subjective and the objective (§212), "the absolute unity of Concept and objectivity" (§213), "the Subject-Object" understood as "the unity of the ideal and the real, of the finite and the infinite, of the soul and the body" (§214). Hegel also says that the "Idea is essentially process" (§215).

Marx applied Hegel's dialectic of subject and object on a more concrete level to the economy in order to explain how the process of economic production works. There is the purposeful activity of human subjects - labour power: "We mean by labour-power, or labourcapacity, the aggregate of those mental and physical capabilities existing in the physical form, the living personality, of a human being, capabilities which he sets in motion whenever he produces a use-value of any kind" (Marx 1867, 270). Labour is the use of labour-power: "The use of labour-power is labour itself. [...] Labour is, first of all, a process by which man, through his own actions, mediates, regulates and controls the metabolism between himself and nature" (Marx 1867, 283).

Labour power is used on an object - the object of labour (Arbeitsgegenstand): The land is "the universal material for human labour" (Marx 1867, 284), "the object of labour counts as raw material only when it has already undergone some alteration by means of labour" (Marx 1867: 284-85). For transforming nature by labour, instruments of labour (technologies) are needed: "An instrument of labour is a thing, or a complex of things, which the worker interposes between himself and the object of his labour and which serves as a conductor, directing his activity onto that object. He makes use of the mechanical, physical and chemical 
properties of some substances in order to set them to work on other substances as instruments of his power, and in accordance with his purposes" (Marx 1867, 285).

The result of the labour process is the labour product: "In the labour process, therefore, man's activity via the instruments of labour, effects an alteration in the object of labour which was intended from the outset. The process is extinguished in the product. The product of the process is a use-value, a piece of natural material adapted to human needs by means of a change in its form. Labour has become bound up in its object: labour has been objectified, the object has been worked on" (Marx 1867, 287). "All 3 moments of the process, whose subject is labour and whose factors are the material on which and the means of labour with which it operates, come together in a neutral result - the product" (Marx 1861-63). In the Economic and Philosophic Manuscripts, Marx argues that the relationship of subject and object results in the objectification of labour in a new product: "The product of labour is labour which has been congealed in an object, which has become material: it is the objectification of labour" (Marx 1844, 69).

Marx terms this whole system the productive forces (see what we term the "dialectical triangle of the work process" in figure 2): human subjects have labour power that in the labour process interacts with the means of production (object). The means of production consist of the object of labour (natural resources, raw materials) and the instruments of labour (technology). In the labour process, humans transform the object of labour (nature) by making use of their labour power with the help of instruments of labour. The result is a product of labour, which is a Hegelian subject-object, or, as Marx says, a product, in which labour has become bound up in its object: labour is objectified in the product and the object is as a result transformed into a use value that serves human needs. The next figure summarizes the dialectical subject-object process in the economy. The productive forces are a system, in which subjective productive forces (human labour power) make use of technical productive forces (part of the objective productive forces) in order to transform parts of the natural productive forces (which are also part of the objective productive forces) so that a labour product emerges. One goal of the development of the system of productive forces is to increase the productivity of labour, i.e. the output (amount of products) that labour generates per unit of time. Marx therefore defined the concept of the development of the productive forces (=the increase of the productivity of labour) as "an alteration in the labour process of such a kind as to shorten the labour-time socially necessary for the production of a [...] [good], and to endow a given quantity of labour with the power of producing a greater quantity of use-value" (Marx 1867, 431). Another goal of the development of the productive forces can be the enhancement of human self-development by reducing necessary labour time and hard work (toil). 


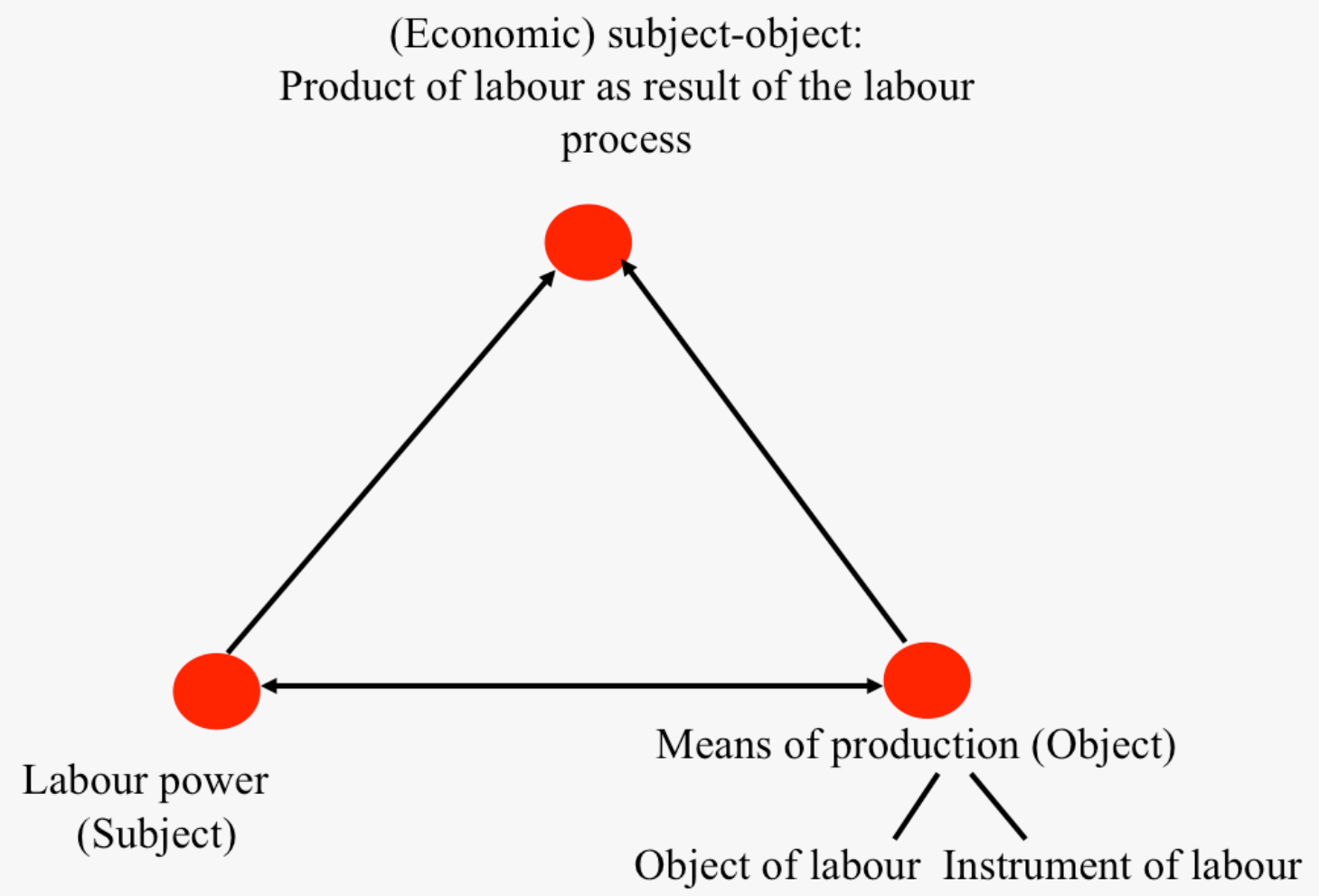

Figure 2: The dialectical triangle of the work process: the system of productive forces - the labour process as dialectical subject-object

\subsection{Labour in Class Societies and Capitalism}

Work in class societies (=labour) is organised in such a way that the products of labour and surplus labour, i.e. labour that goes beyond the time necessary for satisfying basic human needs, is appropriated and owned by a dominant class that exploits the producers of surplus: "Capital did not invent surplus labour. Wherever a part of society possesses the monopoly of the means of production, the worker, free or unfree, must add to the labour-time necessary for his own maintenance an extra quantity of labour-time in order to produce the means of subsistence for the owner of the means of production, whether this proprietor be an Athenian kaloz k'agadoz ['aristocrat'], an Etruscan theocrat, a civis romamts, a Norman baron, an American slave-owner, a Wallachian boyar, a modern landlord or a capitalist (Marx 1867, $334-335)$. Marx $(1857 / 58 b, 238)$ says that in class society "labour will create alien property and property will command alien labour".

Marx focused much of his intellectual efforts on the analysis of capitalism and the role that labour plays therein. The Grundrisse's first part, the "Chapter on money", does not have any specific focus on labour. The term is used here and there, but not in a systematic way and mainly in such a way that it is subsumed to the terms money and commodity. The first real appearance of labour is in the Grundrisse's second part, the "Chapter on capital", namely in a section titled "Exchange value emerging from circulation, a presupposition of circulation, preserving and multiplying itself in it by means of labour" (Marx 1857/58b, 264ff). Marx here makes clear that capital and labour stand in a contradictory dialectical relationship in capitalism, a class relationship: "The labour which stands oposite capital is alien labour, and the capital which stands opposite labour is alien capital" (Marx 1857/58b, 266). The existence of capital depends on the existence of and "connection with not-capital, the negation of capital", i.e. labour. Therefore the "real not-capital is labour" (Marx 1857/58b, 274). The effect of this class relation is that labour faces a dialectic of poverty and wealth, it "is absolute poverty as object" (labour does not own what it produces) and at the same time "the general possibility 
of wealth" (only labour, not capital, produces and is a necessary condition of wealth) (Marx $1857 / 58 b, 296)$. The wealth that labour creates is the wealth of capital and therefore the poverty of labour.

Marx points out that in capitalism the worker sells his/her labour power as commodity to the capitalist and thereby works during one part of the day (necessary labour time) for creating the "value of his labour-power, i.e. the value of his means of subsistence" (Marx 1867, 324) and another part of the day not "for himself", but for the capitalist. During this time, he "creates surplus-value" (Marx 1867, 325). Marx calls this part of the day "surplus labour-time, and to the labour expended during that time I give the name of surplus labour" (Marx 1867, 325). The specific characteristic of capitalism is that labour power becomes a commodity that does not own the means and results of production and is compelled to work a certain share of the day without payment, i.e. to conduct surplus labour, so that surplus value is created that is transformed into capital and monetary profit in the moment the commodity, in which this labour is objectified, is sold on the market. Labour is therefore alienated in a manifold sense.

Marx (1844, 67-83) has the first time used the notion of alienation in a detailed manner in the Economic and Philosophic Manuscripts' section "On estranged labour". He there identifies four forms of alienation: a) alienation from the product, b) alienation from the labour process in the form of forced labour (Marx 1844, 72), c) alienation from himself/herself: "Estranged labour turns thus: (3) Man's species being, both nature and his spiritual species property, into a being alien to him, into a means to his individual existence. It estranges man's own body from him, as it does external nature and his spiritual essence, his human being" (Marx 1844, 76); d) the alienation from other humans and society. On the one hand, the exposition of alienation in the Economic and Philosophic Manuscripts is not as systematic as in the Grundrisse and Capital. On the other hand, Marx focuses more on the anthropological consequences of alienation for the human being and thereby employs the notion of the species-being in his early work. He formulated the foundations of the concept of alienation in the Economic and Philosophic Manuscripts and elaborated later systematically and in more detail the economic foundations of alienation.

For Althusser (1969, 249), Marx's notion of alienation is an "ideological concept" used in "his Early Works". "In his later works, however, the term appears very rarely" (Althusser 1969, 249). Althusser speaks of an "epistemological break" that "divides Marx's thought into two long essential periods: the 'ideological' period before, and the scientific period after, the break in 1845" (Althusser 1969, 34). This means that Althusser considers the notion of alienation and works such as the Economic and Philosophic Manuscripts as esoteric. In contrast, we will show that Marx did not give up the notion of alienation, but that it is rather a concept that he first created in his early works and that is present also in his major writings.

In a passage in the Grundrisse, Marx makes clear which elements of alienation there are in capitalism: the worker is alienated from: a) herself/himself because labour is controlled by capital, b) the material of labour, c) the object of labour, d) the product of labour. "The material on which it [labour] works is alien material; the instrument is likewise an alien instrument; its labour appears as a mere accessory to their substance and hence obectifies itself in things not belonging to it. Indeed, living labour itself appears as alien vis-à-vis living labour capacity, whose labour it is, whose own life's expression it is, for it has been surrendered to capital in exchange for objectified labour, for the product of labour itself. [...] labour capacity's own labour is as alien to it - and it really is, as regards its direction etc. - as are material and instrument. Which is why the product then appears to it as a combination of alien material, alien instrument and alien labour - as alien property" (Marx 1857/58b, 462).

These four elements of alienation can be related to the labour process that consists in a Hegelian sense of a subject, an object and a subject-object, as shown in figure 2. Alienation is alienation of the subject from itself (labour-power is put to use for and is controlled by capital), alienation from the object (the objects of labour and the instruments of labour) and the subject-object (the products of labour). The alienation process is visualized in figure 3. Alienation in capitalism means that workers do not control their labour-power, the means and results of production and are compelled to work part of the day for capital in order to survive. 
The four forms of alienation constitute together the system of the exploitation of labour: labour power due to its manifold alienations is compelled to work without payment for capital, which results in the production of surplus value and monetary profit. Exploitation takes place within specific relations of production - class relations.

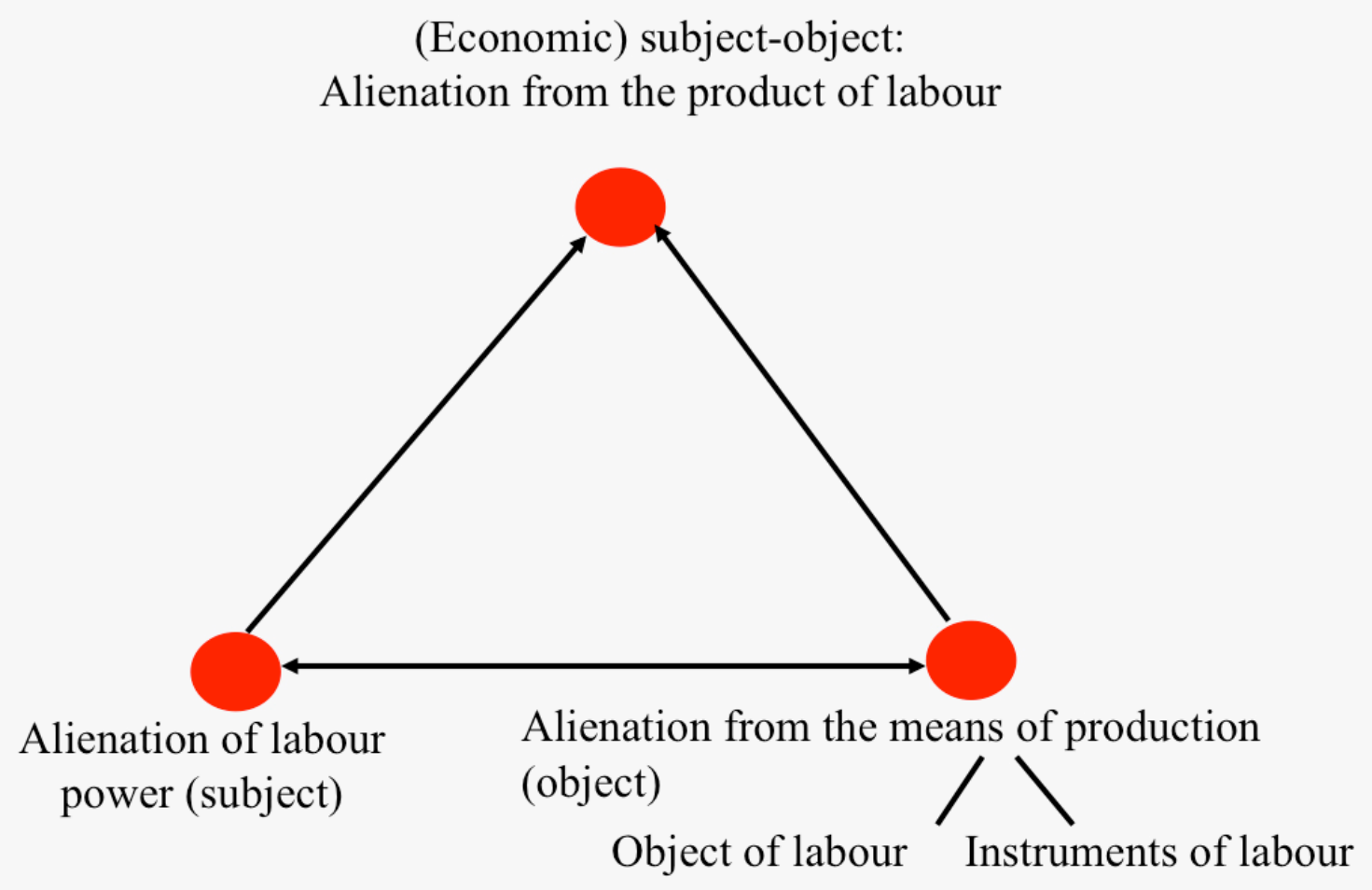

Figure 3: The alienation process in capitalism

Production and the development of the productive forces do not form an abstract process. Although production is a common process in the economy of all societies, it can in reality only take place within concrete historical conditions, in which humans enter certain social relations with each other. Marx speaks in this context of the relations of production. He says that in societies that are based on a division of labour, the relations of production develop into class relations: a dominant class exploits the labour power of a dominated class, which works to a certain extent for free, produces a surplus for others and does not own its own fruits of its labour. The system is enabled by the circumstance that the dominant class privately owns the means of production and has means of violence (physical force, the state and laws, the dull economic compression that forces workers to work for others in order to be able to obtain in return products or money that allow them to consume and to survive) at hand that force the dominated class into being exploited.

Alienation in capitalism makes the worker "double free" - forced to sell his/her labour power on the labour market and propertyless: "the confrontation of, and the contact between, two very different kinds of commodity owners; on the one hand, the owners of money, means of production, means of subsistence, who are eager to valorize the sum of values they have appropriated by buying the labour-power of others; on the other hand, free workers, the sellers of their own labour-power, and therefore the sellers of labour. Free workers, in the double sense that they neither form part of the means of production themselves, as would be the case with slaves, serfs, etc., nor do they own the means of production, as would be the case with self-employed peasant proprietors. [...] The process, therefore, which creates the capital-relation can be nothing other than the process which divorces the worker from the 
ownership of the conditions of his own labour; it is a process which operates two transformations, whereby the social means of subsistence and production are turned into capital, and the immediate producers are turned into wage-labourers" (Marx 1867, 874).

In capitalism, the capitalist class owns the means of production and holds the power to exploit the labour of the proletariat. The latter is forced to sell its labour power as commodity to the capitalists. The proletariat cannot survive without selling its labour power to the capitalists in order to obtain wages. Capitalists need the labour power of the proletariat in order to produce commodities that are sold on markets and contain unpaid surplus value (unpaid labour time) that is transformed into profit so that capital is accumulated. Marx characterizes the capitalist class relation of production as constituting the "antagonistic character of capitalist accumulation", which means that class relations "produce bourgeois wealth, i.e. the wealth of the bourgeois class, only by continually annihilating the wealth" of the proletariat (Marx 1867, 799). Proletarians and capitalists are dialectically connected. The relative "deprivation" of the proletariat and the "plentitude" of capital "match each other exactly" (Marx $1867,1062)$. The proletariat is "a machine for the production of surplus-value," and capitalists are "a machine for the transformation of this surplus-value into surplus capital" (Marx 1867, 742). For Marx, capitalism is based on the capitalists' permanent theft of unpaid labour from workers. This is the reason why he characterizes capital as vampire and werewolf. "Capital is dead labour which, vampire-like, lives only by sucking living labour, and lives the more, the more labour it sucks" (Marx 1867, 342). The production of surplus value "forms the specific content and purpose of capitalist production" (Marx 1867, 411); it is "the differentia specifica of capitalist production," "the absolute law of this mode of production" (Marx 1867, 769), the "driving force and the final result of the capitalist process of production" (Marx 1867, 976).

In capitalism, labour is subsumed under the power of capital: "This natural power of labour appears as a power incorporated into capital for the latter's own self-preservation, just as the productive forces of social labour appear as inherent characteristics of capital, and just as the constant appropriation of surplus labour by the capitalists appears as the constant selfvalorization of capital. All the powers of labour project themselves as powers of capital, just as all the value-forms of the commodity do as forms of money" (Marx 1867, 755f). Marx speaks in this context also of the formal subsumption of labour under capital, which means that the "labour process becomes the instrument of the valorization process" so that "the capitalist intervenes in the process as its director, manager" and engages in the "direct exploitation of the labour of others" (Marx 1867, 1019). Based on this formal subsumption, there is also the real subsumption of labour under capital, where command and coercion are built into machines and the application of science (Marx 1867, 1023-1015) so that productivity increases and labour is indirectly commanded by capital and directly faces the speed and speed-up of production caused by machinery.

Within capitalist relations of production, the productive forces are not just means for producing human wealth and use-values, they are means for the exploitation of the labour of the proletariat and for intensifying this exploitation so that more labour is exploited per unit of time, which results in the production of more commodities in the same time period and in the creation of more surplus value and more profit. Marx therefore speaks of the capitalist antagonism between the productive forces and the relations of production. Within "the capitalist system all methods for raising the social productivity of labour are put into effect at the cost of the individual worker; [...] all means for the development of production undergo a dialectical inversion so that they become means of domination and exploitation of the producers" (Marx 1867, 799).

In capitalism, dead labour (capital) dominates living labour: "The sole antithesis to objectified labour is non-objectified, living labour. The one is present in space, the other in time, the one is in the past, the other in the present, the one is already embodied in a use value, the other, as human activity-in-process, is currently engaged in the process of self-objectification, the one is value, the other is value-creating" (Marx 1861-63).

In section 1.2 of Capital, Volume 1, Marx introduces the distinction between abstract and concrete labour. This distinction reflects the circumstance that Marx wrote both a critique of capitalism and an economic theory at the same book and that these two levels have resulted 
in two series of categories that are both constituents of capitalism, but represent on the one hand that which is specific for capitalism and on the other hand that which forms the essence of all economies and therefore also exists in capitalism and interacts dialectically with capitalism's historic reality. These categories are shown in the table below and constitute for Marx the dual character of capitalism.

\begin{tabular}{|c|c|}
\hline Essential categories & Historic categories \\
\hline Work & Labour \\
\hline Use-value & Exchange value \\
\hline Concrete labour & Abstract labour \\
\hline Labour process & Valorisation process \\
\hline Necessary labour & Surplus labour \\
\hline
\end{tabular}

Table 1: Marx's description of the dual character of capitalism

Marx explains that concrete labour is the use-value generating aspect of labour (work) and that abstract labour creates value. "While, therefore, with reference to use-value, the labour contained in a commodity counts only qualitatively, with reference to value it counts only quantitatively, once it has been reduced to human labour pure and simple. In the former case it was a matter of the 'how' and the 'what' of labour, in the latter of the 'how much', of the temporal duration of labour. Since the magnitude of the value of a commodity represents nothing but the quantity of labour embodied in it, it follows that all commodities, when taken in certain proportions, must be equal in value" (Marx 1867, 136).

Abstract labour is that kind of labour which makes the privately spent use-value producing work comparable. Abstract labour describes a specific quality of a capitalist mode of production. Marx says: "Equality in the full sense between different kinds of labour can be arrived at only if we abstract from their real inequality, if we reduce them to the characteristic they have in common, that of being the expenditure of human labour-power, of human labour in the abstract" (Marx 1867, 166). In the concept of abstract labour, several abstractions from the concrete are involved. These abstractions mirror real social relations that are established by commodity exchanges in capitalism. By exchanging commodities, producers abstract from the specific quality of the work that was involved to produce a commodity. This means that there is:

a) an abstraction from the physical properties of goods (their use-values),

b) an abstraction from single products so that social relations between commodities in exchange are established,

c) an abstraction from simple labour activities to more complex tasks,

d) an abstraction from specific qualities under which specific labour processes took place (such as bad working conditions, low payment, etc) so that common properties of commodities are foregrounded by the value concept.

Abstract human labour is the substance of value; it is a common characteristic of commodities. Abstract human labour creates the value of a commodity, i.e. it is the performance of the (average) labour in a certain time span that is needed for producing a commodity. "A use-value, or useful article, therefore, has value only because abstract human labour is objectified [vergegenständlicht] or materialized in it" (Marx 1867, 129). The values of commodities are "determined by their cost of production, in other words by the labour time required to produce them" (Marx 1867, 137). The magnitude of value is measured "by means of the quantity of the 'value-forming substance', the labour, contained in the article. This quantity is measured by its duration, and the labour-time is itself measured on the particular scale of hours, days, etc" (Marx 1867, 129). The value of commodities as determined by labour time is only their average value" (Marx 1857/58b, 137). "If we consider commodities as values, we consider them exclusively under the single aspect of realized, fixed, or, if you like, crystallized social labour" (Marx 1865).

Marx distinguishes between productive and unproductive labour: "Productive labour is only that which produces capital. [...] Labour becomes productive only by producing its own 
opposite" (Marx 1857/58b, 305). "The only worker who is productive is one who produces surplus-value for the capitalist, or in other words contributes towards the self-valorization of capital" (Marx 1867, 644). In this context, the question arises if only wage labour is productive or if also non-wage labour can be productive. Marx gave an answer in the Grundrisse.

In the section "'Exchange value emerging from circulation, a presupposition of circulation, preserving and multiplying itself in it by means of labour" (Marx 1857/58b, 264ff) in the Grundrisse's "Chapter on money", Marx argues that capital and labour confront each other in an exchange relationship, in which the use-value of labour - labour power - is exchanged with money. It thereby becomes clear that Marx's main focus in the Grundrisse is on wage labour. Antonio Negri $(1979 / 1988,165)$ argues in this context that in the Grundrisse, "labour can only be defined in terms of the relations of exchange and the capitalist structure of production. The only concept of labour that we find in Marx is that of wage labour". Work would therefore be nothing "to be reformed, reinstated, liberated, or sublimates; it exists only as a concept and a reality to be abolished" (Negri 1979/1988, 165). Negri does not distinguish between work and labour, but conceives both as necessarily alienated. Negri (1979/1988) also sees that Marx focused his attention in the Grundrisse on wage-labour, but does not further prolematise this circumstance, although the Grundrisse are Marx's work that Negri most cherishes. The German language just like English allows in principle to make a distinction, namely between Werktätigkeit (work as the activity of bringing about works) and Arbeit (labour).

But there is also a formulation in the Grundrisse, where Marx sees labour as communal or combined labour (Marx 1857/58b, 470), as collective worker (Gesamtarbeiter). This idea was also taken up in Capital, Vol. 1, where he defines the collective worker as "a collective labourer, i.e. a combination of workers" (Marx 1867, 644) and argues that labour is productive if it is part of the combined labour force: "In order to work productively, it is no longer necessary for the individual himself to put his hand to the object; it is sufficient for him to be an organ of the collective labourer, and to perform any one of its subordinate functions" (Marx $1867,644)$. The collective worker is an "aggregate worker" whose "combined activity results materially in an aggregate product" (Marx 1867, 1040). The "activity of this aggregate labourpower" is "the immediate production of surplus-value, the immediate conversion of this latter into capital" (Marx 1867, 1040). This means that in capitalism, the collective worker is a productive worker that creates value, surplus value and capital. The notion of the collective worker allows an interpretation of Marx that is not wage labour-centric because the collective worker as combined work force also contains all those activities that are unpaid, but directly or indirectly serve capital's needs. David Harvie (2010) suggests theorizing the distinction between productive and unproductive work/labour as defined by social struggles. It is capital's tendency to render all work productive and to make it value-producing labour, but this tendency can be struggled against so that work remains or becomes unproductive in the sense of being independent from capital. An example is that a company is taken over by the workers and transformed into a self-managed non-profit company.

One question of particular relevance in this context is the the one about the status of reproductive labour that is mostly conducted by women. Labour power needs to be reproduced, i.e. there are certain activities during a certain time period of the day that help the worker recreate and sustain his/her labour capacity. "The value of labour-power is determined, as in the case of every other commodity, by the labour-time necessary for the production, and consequently also the reproduction, of this specific article" (Marx 1867, 274). This includes means of subsistence for workers and their families, practice, training, education, etc (Marx 1861-63). This means that there are activities that need to be performed by someone and that reproduce labour power. One can in this context speak of reproductive labour, which is a form of labour that is mostly unpaid. Non-wage labour "ensures the reproduction of labour power and living conditions" (Mies, Bennholdt-Thomsen and Werlhof 1988, 18). It is labour spent "in the production of life, or subsistence production" (Mies, Bennholdt-Thomsen and Werlhof 1988, 70). 


\subsection{Work in Communism}

Based on the distinction between work and labour, one can say that for Marx communism is a society without labour because alienation ceases to exist. There are passages in his works, where he points out how the conditions of non-alienated work look like. The main condition of communism is that the means of production are collectively owned: "Let us finally imagine, for a change, an association of free men, working with the means of production held in common, and expending their many different forms of labour-power in full self-awareness as one single social labour force" (Marx 1867, 171-172).

In the Grundrisse's "Fragment on Machines" (Marx 1857/58b, 690-712), Marx argues that the development of capitalism's productive forces results in an increased role of technology (fixed constant capital) and thereby historically increases the importance of science and knowledge work in the economy and society. One can read this section of the Grundrisse as an early forecasting of the emergence of what is nowadays called information society. Marx also points out the transformation of work in a communist society: It would not be based on the "theft of alien labour time" (Marx 1857/58b, 705), but on the "free development of individualities" enabled by the "general reduction of the necessary labour of society to a minimum, which then corresponds to the artistic, scientific etc. development of the individuals in the time set free, and with the means created for all of them" (Marx 1857/58b, 706). If technology reduces necessary labour time to a minimum and class relations are abolished, a new source of wealth would emerge: "The measure of wealth is then not any longer, in any way, labour time, but rather disposable time" (Marx 1857/58b, 604).

The Grundrisse make clear the importance of technology and science for raising productivity to levels that enable communism. In the German Ideology, Marx and Engels stress that high productivity allows overcoming the division of labour and to transform work in such a way that it becomes well-rounded manifold activity: "in communist society, where nobody has one exclusive sphere of activity but each can become accomplished I any branch he wishes, society regulates the general production and thus makes it possible for me to do one thing today and another tomorrow, to hunt in the morning, fish in the afternoon, rear cattle in the evening, criticise after dinner, just as I have a mind, without ever becoming hunter, fisherman, shepherd or critic" (Marx and Engels 1845/46, 53). Once "the productive forces have also increased with the all-around development of the individual, and all the springs of cooperative wealth flow more abundantly" (Marx 1875), a communist society that is based on the principle "From each according to his ability, to each according to his needs!" (Marx 1875) can be established.

In another passage in the Grundrisse, Marx introduces the idea that work becomes general in communism and speaks of general work. This includes "the participation of the individual in the communal world of products" (Marx 1857/58b, 171), "communal production" (172), "an organization of labour whose consequence would be the participation of the individual in communal consumption" (172). This means that in a communist society, workers control the production process together and collectively own the instruments and products of labour. In communism, work is general and universal because ownership and control of the conditions, instruments, objects and products of work have been generalised so that there is universal control and ownership of production. As in the German Ideology, Marx employs the notion of well-rounded development (Marx 1857/58a, 105; Marx 1857/58b, 172 ${ }^{5}$ ) that "depends on economization of time" so that "[e]conomy of time" is that to which "all economy ultimately reduces itself" (Marx 1857/58a, 173). Communism requires a labour-saving economy achieved with the help of highly productive technologies. General labour operates in the context of such an economy. Common ownership and high productivity give a new character to work in a communist society. Work is no longer labour and no longer alienated, the labour process and all its elements are rather commonly controlled (foreign ownership is eliminated), self-determined time is maximized, work can become manifold and an expression of

\footnotetext{
5 "Allseitigkeit ihrer Entwicklung" has here been translated as "multiplicity of its development". But in order to be consistent with the terminology in the German Ideology, a more adequate translation would be to speak of the "well-roundedness of its [society's] development"
} 
manifold creative activities that do not primarily satisfy human necessities, but rather human pleasures that go beyond necessity and do not know the phenomenon of scarcity. Labour is transformed into work.

De-alienation means for Marx the end of specific capitalist aspects of work; hence the end of labour. But this also includes the end of non-capitalist forms of alienation. De-alienation presupposes the abolition of private property of the means of production and the sublation of the division of labour. As a consequence, members of society can then consciously reduce working time that is necessary to foster the flourishing of human work. In such a society, free time emerges that will be used for another type of work that can be termed "attractive work" or "pleasurable work". Humans will be able to express themselves in unlimited and manifold ways (see section 4).

\section{Digital Work and Digital Labour on Facebook}

In this section, we will discuss how to apply Marx's theory of work and labour to the realm of online media. We on the one hand develop general arguments and on the other hand use Facebook as an example in order to make the abstract discussion more concrete. Facebook is particularly suited as case because it is the most popular "social medium" and uses a capital accumulation model that cannot work without the commodification of users' online activities. The discussion can also be applied to other forms of social media.

\subsection{Digital Work}

Raymond Williams focuses in his essay "Means of communication as means of production" on the structures of communication, i.e. media (including language and mass media), and argues that they are means of production and therefore "indispensable elements both of the productive forces and of the relations of production" (Williams 1980, 50). His focus on structures leaves however out the focus on the subjects' practices and the question if communication is a form of work. The most concrete way he addresses this issue is by saying that languages and communication are "forms of social production" (Williams 1980, 55).

Conscious thinking and talking had their origin in the process of the objectification of the human subject in nature and develop within work, argues Frederick Engels in The Part Played by Labour in the Transition from Ape to Man (Engels 1895/1896). Work necessitates the development of consciousness and language. This is a consequence of the dialectical relationship between the object and the subject in the work process. Not only the subject shapes the object, but also the subject is shaped by the object in the work process. Critical psychologists, such as Lew S. Wygotski, Alexei N. Leontjew and Alexander R. Lurija, built and elabourated on Marx's and Engels' ideas on work, consciousness and language. The term 'activity' became crucial for their critical psychological approach. Leontjew argued: "Entering into contact with each other, people also formulate a language that serves to represent the objects, the means, and the very process of work itself. [...] Behind philological meanings is hidden social practice, activity transformed and crystallized in them; only in the process of this activity is objective reality revealed to man" (Leontjew 1978). The meaning of activity in critical psychology comes close to our proposed broad understanding of work that is based on Marx. If there is a similar structure between work activities, such as transforming nature, thinking, communication, and co-operation and if all these activities are related (no transforming of nature without thinking and talking) and stem from the basal activity of transforming nature, then it becomes imaginable that also the activities of thinking (cognition), communication and co-operation produce societal surplus in any form and can be exploited like traditional work can be.

A question related to the relationship of work and communication is the role of nature in production and the issue if the object of work is necessarily taken from nature. "It is possible that the material of labour, the object to be appropriated by means of labour for a specific need, is available in nature without the assistance of human labour: the fish caught in water for example, or the wood felled in the primeval forest, or the ore brought up out of the pit. In such a case only the means of labour itself is a product of previous human labour. This char- 
acterises everything that can be called extractive industry; it only applies to agriculture to the extent that, say, virgin soil is being cultivated" (Marx 1861-63). This quotation shows that Marx considered nature just as one possible object of work that occurs in agricultural work and mining. This implies that also fabricated nature can be the object of work. Agricultural and extractive work takes nature as the object, industrial work takes fabricated nature as the object, information work takes ideas and human subjectivity as the object. Marx described the latter possibility in the Grundrisse's "Fragment on Machines" as a consequence of capitalism's technological progress, in which fixed constant capital in the form of machines becomes historically ever more important in production in order to increase productivity, which is a development that is accompanied by the rising relevance of information work. He coined the notion of the general intellect in this context: "The development of fixed capital indicates to what degree general social knowledge has become a direct force of production, and to what degree, hence, the conditions of the process of social life itself have come under the control of the general intellect and been transformed in accordance with it. To what degree the powers of social production have been produced, not only in the form of knowledge, but also as immediate organs of social practice, of the real life process" (Marx 1857/58b, 706).

Most Marxist approaches that have given attention to the communication process at a theoretical level have focused on the communicative character of work, but have neglected the question if communication is work. They stress that work requires communication and is organised with the help of communication and human communication emerged and is reproduced in interaction with human work. Conventional communication theory sees the material and the ideal as two separate realms of society, labour and interaction are seen as being alien to and independent from each other (Hund 1976, 272f).

Language is the result of human activities over many generations. Words are not natural objects, but produced by humans together in their culture. As being produced by humans, information is the product of human work. Hands, head, ears, mouth - body and brain - work together in order to enable speech. Work has a dual character, it has physical and social dimensions. Thinking and speaking that result in the production of information and symbols form the physical aspect, human relations the social dimension of communication (Hund and Kirchhoff-Hund 1980).

The previous discussion tried to assemble arguments to make plausible that the activities of cognition, communication and co-operation are forms of work. Information can be conceived as a threefold process of cognition, communication and co-operation (Fuchs and Hofkirchner 2005; Fuchs, Hofkirchner, Schafranek, Raffl, Sandoval and Bichler 2010; Hofkirchner 2002). The table below gives an overview of the dimensions of cognitive, communicative and cooperative work.

\begin{tabular}{|l|l|l|l|l|}
\hline & Subject & $\begin{array}{l}\text { Object of } \\
\text { work }\end{array}$ & $\begin{array}{l}\text { Instruments of } \\
\text { work }\end{array}$ & Product of work \\
\hline $\begin{array}{l}\text { Cognition = human brain } \\
\text { work }\end{array}$ & $\begin{array}{l}\text { Human be- } \\
\text { ing }\end{array}$ & Experiences & Brain & $\begin{array}{l}\text { Thoughts, cognitive pat- } \\
\text { terns, ideas }\end{array}$ \\
\hline $\begin{array}{l}\text { Communication = human } \\
\text { group work }\end{array}$ & $\begin{array}{l}\text { Group of } \\
\text { humans }\end{array}$ & Thoughts & $\begin{array}{l}\text { Brain, mouth, } \\
\text { ears }\end{array}$ & Meaning \\
\hline $\begin{array}{l}\text { Co-operation = collabo- } \\
\text { rative human group work }\end{array}$ & $\begin{array}{l}\text { Group of } \\
\text { humans }\end{array}$ & Meaning & $\begin{array}{l}\text { Brain, mouth, } \\
\text { ears, body }\end{array}$ & $\begin{array}{l}\text { Information product with } \\
\text { shared and co-created } \\
\text { meaning }\end{array}$ \\
\hline
\end{tabular}

Table 2: The subject, object and subject-object of cognitive, communicative and co-operative work

The figure below shows that these three processes are connected dialectically and form together the process of information work. Each of the three behaviours - cognition, communication and co-operation - is a work process: cognition is work of the human brain, communication work of human groups and co-operative collaborative work of human groups. Communication is based on cognition and uses the products of cognition - ideas - as its object of work. Co-operation is based on communication and uses the products of communication meanings - as object of work. Information is a work process, in which cognitive work creates 
ideas, communicative work creates meanings and co-operative work co-creates information products that have shared and co-created meaning. Information is a dialectical process of human work, in which cognition, communication and cooperation are dialectically connected. Each of these three processes forms a work process that has its own subject-object-dialectic in itself.

Using the Hegel-Marxist triangle model of the work process (see the "dialectical triangle model of the work process" in figure 2), one can argue that the development that Marx points out on behalf of the notion of the general intellect can be formalised as follows: S-O>SO ... SSO>SSO... S-SSO>SSSO and so forth. The object position of a dialectical work triangle starts with the result, the subject-object of a previous triangle and so on. The advantage of this kind of thinking is that the reference to an object and ultimately nature never gets completely lost in the theory. Hence a dualism between subject and object, e.g. communication and work is prevented. Dialectical thinking is capable of providing an integrative theory of human activity.

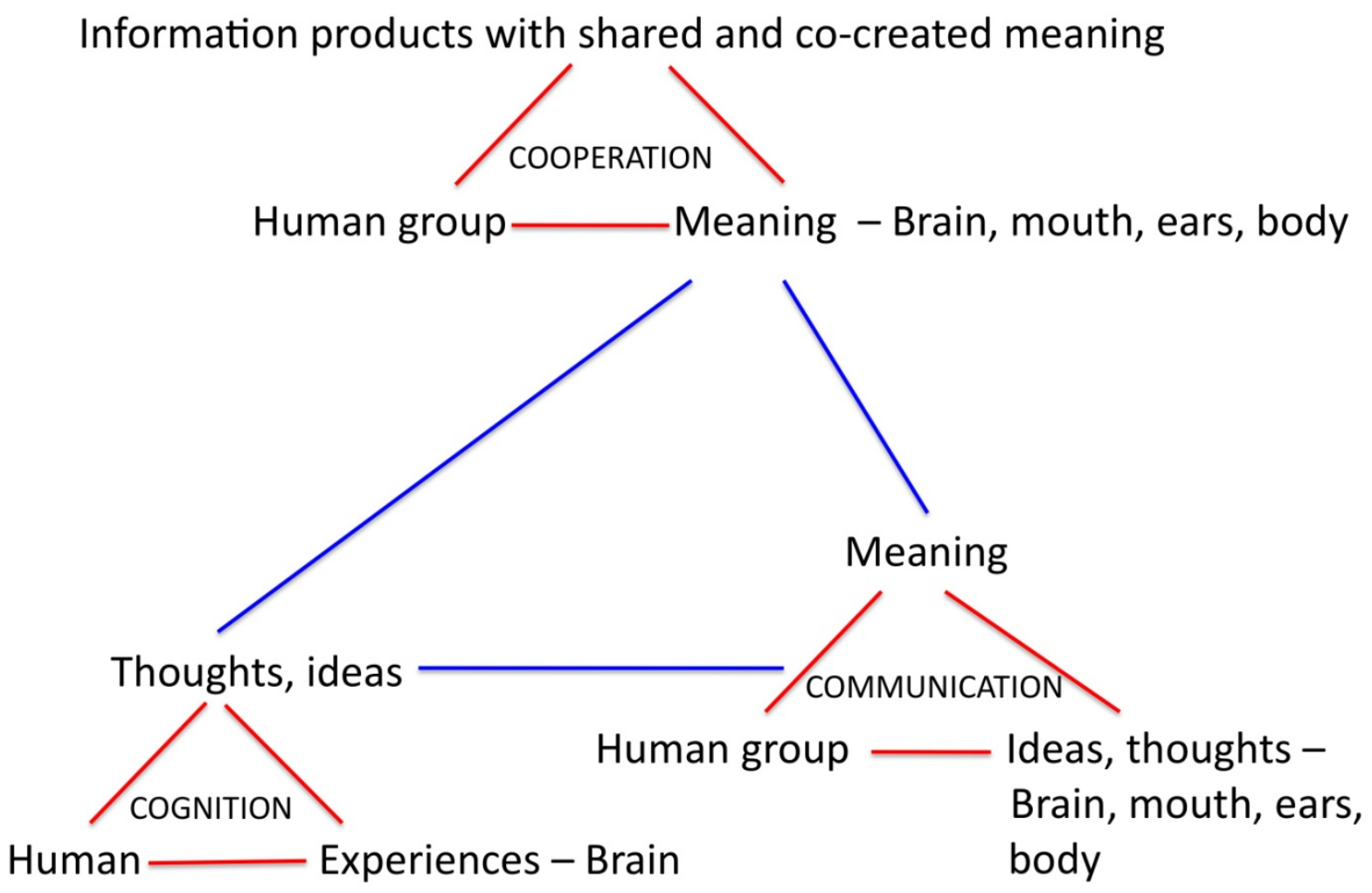

Figure 4: The information process as work process

An example: A person likes reading books about gardening and builds up a sophisticated knowledge of how to create and maintain a good-looking garden by reading more and more books and applying this knowledge in his/her garden. The created knowledge is a use-value in the sense that it helps him/her organise her/his own garden in a nice-looking manner. S/he meets another person, who has comparable knowledge. They start exchanging ideas on gardening. In this communication process, the shared knowledge of one person forms an object that is interpreted by the other person so that meaning, i.e. an interpretation of parts of the world, is formed. The process also works vice-versa. As a result, meanings are created as use-values on both sides; each person understands something about the other. After continuous conversations and mutual learning, the two hobby gardeners decide to write a book 
about gardening. They develop new ideas by discussing and bring their experiences together, whereby synergies, new experiences and new gardening methods emerge. In the book, they describe these new methods that they have tried in practice in a jointly run garden. The representations of the joint experiences and of the co-created methods in the form of a book are a use-value not just for the two, but for others too.

Work requires information processes and information creation is itself a work process. This model allows (in contrast to Habermas' approach) a non-dualistic solution to the question of how work and information/interaction are connected. It avoids separations between nature/culture, work/interaction, base/superstructure, but rather argues that information has its own economy - it is work that creates specific use-values. These use-values are individual in character only at the level of cognition - the human thinks and develops new ideas -, whereas they have a direct social character at the level of communication and co-operation. But humans do not exist as monads, the objects of cognitive work stem to a large degree from society itself. To interpret the information creation process as work is not philosophical idealism because idealism sees spirit as independently existing entity that is not connected to human labour. Ideas, meanings and co-created information products are objects of labour that reflect society in complex ways.

Every work process requires cognition, communication and cooperation as tools of production. Therefore the physical production of goods in manufacturing as well as agricultural work and mining are never separate from information processes. This aspect has been stressed in many Marxist analysis of the connection of communication and work. In these production forms, information is not a product, but a means of production. Work requires information. The other way round, information is also work: there is an informational mode of production that has grown in size in the $20^{\text {th }}$ century (in terms of the population active in it and share of the overall created value in the economy): it focuses on the production of informational goods and services. It is this kind of production that is the main focus of our attention in this paper. Work requires information and communication. But at the same time, it is important to give attention to information and communication as forms of work.

In the digital labour debate, there are authors who stress that Facebook and other commercial online media whose profits are based on targeted advertising are grounded in the exploitation of users' labour and the commodification of personal data (e.g. Andrejevic 2011, 2012; Fuchs 2010, 2012a). In this context, Marxist labour theories of value that were applied to commercial mass media have been employed and updated, namely Dallas Smythe's (1977, 1981) concept of audience work/audience commodity (Fuchs 2010, 2012a) and Sut Jhally and Bill Livant's (1986/2006) notion of the work of watching (Andrejevic 2009). Others have stressed that "social media" enable participatory culture (Jenkins 2006) or enable a "'making and doing' culture" (Gauntlett 2011, 11) and everyday creativity (Gauntlett 2011, 221). This debate can be interpreted with the help of Marx's analysis of the dual character of labour as concrete work that produces use-values and abstract labour that generates value.

In concrete work, human subjects equipped with labour power apply instruments to objects in order to create products that satisfy human needs. On Facebook, labour power is predominantly informational work. Information is a threefold process of cognition, communication and co-operation. On Facebook, users publish information about their life, which means that they objectify their subjective knowledge that is grounded in their experiences in society in such a way that they create and update their user profiles. This is the stage of cognitive work on Facebook. Users also communicate with others by using the messaging function or writing comments on walls or community pages. In this process, users externalize parts of their cognitive knowledge in the symbolic exchange of messages with other users. If the interaction is reciprocal, then subjective knowledge of one user becomes objectified in the brains of at least one other user and the other way round. This objectification of subjective knowledge means that users interpret the messages of others and thereby change their thought patterns to a certain degree. Communicative work on Facebook means the mutual symbolic interchange of subjective knowledge that results in meaning-making that is internalized. 
Facebook is also a community, which means that repeated communication between users results in or maintains friendships and personal relations that involve feelings of belonging together. Furthermore is also a space of collaboration, where users together try to strategically achieve goals such as saving money by organising online ridesharing, exchanging or giving away furniture or clothes, or community pages that enable the joint activities of guerrilla gardeners, guerrilla knitters etc. Online community and online collaboration are both expressions of co-operation: humans come together online to create something new, either social relations that involve feelings of togetherness or social relations that enable the collaborative creation of novel objects in the world. Facebook enables these co-operation processes, they are grounded in human cognition and communication, from which a new quality of a social system emerges by repeated and routinized interactions that create results on a higher level of social organisation.

Facebook is a realm of cognitive, communicative and co-operative activities. But why are these activities work? According to Marx, in order to speak of work, there must be an interaction of labour power with objects and instruments of work so that use-values are created as products. The table below summarises these elements in relation to the three forms of digital work. In cognitive digital work, humans make use of their brains, mouths, speech, ears, hands, the Internet and platforms (such as Facebook) as instruments in order to organise parts of their experiences that form an object so that a transmogrified representation of these experiences is created in the online realm, e.g. in the form of a blog post, a user profile or an online video. In communicative digital work, experiences of at least two human subjects (either objectified in an online form or in human brains) form an object that is transformed with the help of symbolic interaction that is enabled by online media, human brains, mouths, speech, and ears so that new meanings about the world and new experiences are created on the side of the involved individuals and social relationships are established. New meanings and (the creation or maintenance of) social relations are the use-values of communicative work. Co-operative digital work organises human experiences that are given in the form of human thought, online information or joint meanings and existing social relations with the help of online media, human brains, mouths, speech, ears and hands in such a way that new artefacts, communities or social systems are created. A social system is a routinized social relationship that involves behaviour that follows certain rules and exists over a longer time period. All three forms of digital work have a common ground: Digital work is the organisation of human experiences with the help of the human brain, digital media and speech in such a way that new products are created. These products can be online information, meanings, social relations, artefacts or social systems. Digital work is grounded in what Marx termed the species-being and the sensuous being of humans, which means that they are creative and productive as well as social beings with language competence. Man is "a social (i.e., human) being" (Marx 1844, 102), his/her "existence is social activity. Therefore what I create from myself I create for society" (Marx 1844 ${ }^{6}$ ).

\begin{tabular}{|l|l|l|l|}
\hline & Object of work & Instruments of work & Product, use-value \\
\hline $\begin{array}{l}\text { Cognitive digital } \\
\text { work }\end{array}$ & Human experiences & $\begin{array}{l}\text { Human brains, hands, } \\
\text { mouths, ears, speech, Inter- } \\
\text { net, platforms }\end{array}$ & $\begin{array}{l}\text { Online information, pro- } \\
\text { files }\end{array}$ \\
\hline $\begin{array}{l}\text { Communicative } \\
\text { digital work }\end{array}$ & $\begin{array}{l}\text { Human experiences, online } \\
\text { information }\end{array}$ & $\begin{array}{l}\text { Human brains, hands, } \\
\text { mouths, ears, speech, Inter- } \\
\text { net, platforms }\end{array}$ & $\begin{array}{l}\text { New meanings estab- } \\
\text { lished in social relation- } \\
\text { ships }\end{array}$ \\
\hline $\begin{array}{l}\text { Co-operative digi- } \\
\text { tal work }\end{array}$ & $\begin{array}{l}\text { Human experiences, online } \\
\text { information, online social re- } \\
\text { lations }\end{array}$ & $\begin{array}{l}\text { Human brains, hands, } \\
\text { mouths, ears, speech, Inter- } \\
\text { net, platforms }\end{array}$ & $\begin{array}{l}\text { Artefacts, communities, } \\
\text { social systems }\end{array}$ \\
\hline
\end{tabular}

Table 3: Three forms of digital work

That "general social knowledge has become a direct force of production" means that at a certain stage of development, knowledge not only, but still plays an indirect role for the economy in the form of educational skills provided by schools, universities, libraries and other

\footnotetext{
${ }^{6}$ http://www.marxists.org/archive/marx/works/1844/epm/3rd.htm
} 
cultural institutions, but has also a role in the economy in the form of information work that creates informational products. In contemporary capitalism these informational products are often produced and sold in a capitalist manner. Based on a reading of Marx's "Fragment on Machines", Italian Autonomist Marxists have formulated the concept of immaterial labour. Maurizio Lazzarato introduced this term, by which he means "labour that produces the informational and cultural content of the commodity" (Lazzarato 1996, 133). Michael Hardt and Antonio Negri have popularized this notion and define immaterial labour as labour "that creates immaterial products, such as knowledge, information, communication, a relationship, or an emotional response" (Hardt and Negri 2004, 108).

Theorists of cognitive capitalism have explored the role of immaterial labour in contemporary capitalism (Vercellone 2007; 2010; Boutang 2012; for an overview see Mezzedra and Fumagalli 2010; Cvijanovic, Fumagalli and Vercellone 2010). Boutang proposes "to split living labour into two, and to assume that - alongside living labour as an expenditure of energy that will be partially consumed and crystallised into new machinery in the following cycle - there is a living labour that continues to exist as a means of production throughout the cycle. [...] It builds itself as a skill, as a know-how resistant to its reduction to pure human capital that can be objectified" (Boutang 2012, 93). The term "immaterial" and Boutang's definition of labour create the impression that information work is detached from nature and matter and that there are two substances in the world - matter and spirit - that result in two different types of work (see also Fine, Jeon and Gimm 2010; Jeon 2010). Information work is however not detached from nature and matter, but is material itself. It is based on the activity of the human brain, which is a material system that is part of the human's materiality. If the spirit is presented as being detached from nature and matter, as post-operaist accounts often do, then one leaves the realm of a materialistic analysis of society and enters the realm of spiritualism, esotericism and religion, in which spirit is an immortal substance.

Are human cognition, communication and co-operation really work? Jürgen Habermas has contested this view. He argues that Marx, Lukács, Horkheimer and Adorno expanded "the teleological concept of action" and thereby relativized "purposive rationality against a model of reaching understanding" (Habermas 1984, 343). The strong focus on instrumental reason would not provide enough consideration of communicative rationality. Marx would therefore dialectically clamp together "system and life-world so that the intersubjectivity of workers associated in large industries is crippled under the self-movement of capital" (Habermas 1987, 340). As a consequence, Habermas makes a sharp distinction between on the one hand purposive (instrumental, strategic) action that is oriented to success and on the other hand communicative action that is oriented on reaching understanding (Habermas 1984, 285f). Work is for Habermas always an instrumental, strategic and purposive form of action.

Habermas misinterprets Marx by not seeing that the latter gives attention to both the anthropological and historical side of human activity. In the concepts of the species-being and the sensuous being, Marx conceives the human as a producing and communicating being. He uses in this context the notion of the species-being and the sensuous being. The speciesbeing is an economically producing, i.e. working being: "It is just in the working-up of the objective world, therefore, that man first really proves himself to be a species being. This production is his active species life. Through and because of this production, nature appears as his work and his reality" (Marx 1844, 76). The sensuous being is among other things a speaking and communicating being: "The element of thought itself-the element of thought's living expression-language-is of a sensuous nature. The social reality of nature, and human natural science, or the natural science about man, are identical terms" (Marx 1844, 111f). Communication is enabled by the interaction of the two human senses of speaking and hearing. But these senses can, as Marx points out, never exist in isolation, but only in social relations: "For his [the human's] own sensuousness first exists as human sensuousness for himself through the other man" (Marx 1844, 111). "Language itself is the product of a community, just as it is in another respect itself the presence of the community" (Marx 1857/58b, 490). Language "is practical, real consciousness that exists also for other men as well, and only therefore does it also exist for me; language, like consciousness, only arises from the need, 
the necessity of intercourse with other men" (Marx and Engels 1845/46, 49). For Marx, the human being is not necessarily an instrumental being because he stresses on the one hand the dimensions of sensuousness, speech and communication and on the other hand points out that work is not always and not necessarily a necessity and an instrument to achieve goals, but under communism becomes a free activity beyond necessity and instrumentality.

Habermas mistakenly claims that Marx did not take into account communication when describing humans in society, but focused on work and instrumentality instead. As we have tried to show, Marx in his analysis of the human as species-being and sensuous being saw both the aspects of work and information as constitutive of human existence. The Italian post-operaists have foregrounded based on Marx that information has become a productive force in many contemporary economies. The analytical consequence we can draw from this discussion is that it does not make sense to separate information and work as two realms of human existence, as Habermas does in his theory. One should rather see work as a broad category constitutive of the human that includes different types of work, such as agricultural work, industrial work and informational work. Work on Facebook is informational work that is organised with the help of digital media that are based on the Internet. Digital work is a specific form of informational work that makes use of digital media as an instrument of work that is employed together with the human brain to organise human experiences in such a way that symbolic representations, social relations, artefacts, social systems and communities emerge as new qualities.

\subsection{Digital Labour}

We have argued that a conceptual distinction between work and labour should be made and that labour is based on a fourfold alienation of the human being: the alienation from oneself, the alienation from the objects of labour (instruments and objects of labour) and the alienation from the created products. This fourfold alienation constitutes an alienation from the whole production process that is due to the existence of class relations and results in exploitation. We will now apply this discussion to the realm of the digital and the case of Facebook.

Alienation of labour power means for Marx that humans have to let capital control their productive activities for a certain share of the day in order to be able to survive. One argument that one can sometimes hear when talking about digital labour is that Facebook users are not exploited because nobody forces them to use the platform, but that they rather do so voluntarily and have fun in doing so. Humans in order to exist not only have to eat, but also must enter social relations, communicate and form friendships. Isolation of an individual from communication and social networking will ultimately result in either death or an animal-like existence. Speech and the brain are at the heart of human communication power. They can only be put to use in social relations, in the connection with other humans. In an information society, digital media have for many become important means of interaction that humans employ for putting to use their communication power. Labour power is therefore partly communication power. If one wants to use a social networking site (SNS) for communicating with others, then Facebook is the most likely option because it controls a very large number of users and their profiles, which makes it very likely that individuals engage in a significant number of meaningful communications if they access Facebook. If they do not use Facebook, their lives may involve a smaller number of meaningful interactions. This is especially true for young people, who are the most active users of Facebook and who tend to organise everyday activities (such as parties, going out, small talk, entertainment, etc) with the help of social media. The coercion exercised by Facebook on users is not one that makes them die physically as in the case of the worker, who does not find paid employment and gets no benefits, it is rather a social form of coercion that threatens the user with isolation and social disadvantages. Facebook users are not paid for their labour; they are unpaid workers. For Marx, exploitation does not necessarily presuppose a wage. Slaves or houseworkers are examples for unpaid workers, who are exploited by slave masters and family heads. Both slaves and houseworkers existed in pre-capitalist modes of production that have been transformed, but 
not abolished in capitalism. They are part of a collective worker that creates value and is in this process exploited by capital.

The main instruments of labour on Facebook are the platform itself and the brains of its human users. Alienation of users' brains means that there are attempts to diffuse ideologies that present Facebook and other corporate platforms as purely positive and as not having negative impacts. These ideologies can be summarised with statements such as: "Web 2.0 is a form of democratic communication and participatory culture", "Facebook is free and always will be", "The world will be better if you share more", "Facebook makes the world more open and connected", "Facebook helps promoting understanding between people", "Facebook creates an open society", "Facebook revolutionizes how people spread and consume information", "Facebook gives people a voice", "The Arab spring was a Facebook revolution", "Facebook is a network built from the bottom-up rather than one of the monolithic top-down structures that have existed to date", etc. It is a separate question what the role of Facebook is in culture, everyday life and politics, but it is a fact that such statements that are typically used in marketing, public relations and advertising leave out talking about negative impacts, commodification and who controls ownership and profits. That these are ideologies does not mean that they necessarily dupe users, but that there are attempts to paint one-sided pictures of Facebook and other media that leave out problematizing parts of the reality of Facebook. The overall aim is to achieve more users and make users spend ever more time on Facebook. Similar ideologies can be found also in the context of other corporate online media. Facebook's capital accumulation model is based on targeted advertisements. The content of these ads is mainly focused on promoting certain commodities. Facebook ads aim at hailing the users to buy specific commodities. Ads are ideological in the sense that they often make overdrawn claims about commodities and present the latter as the best thing that exists in the world and as something that one must possess in order to lead a good life. The goal is to make consumers buy these commodities and to shape their needs and desires in such a way that they feel that they have to possess these goods. Instrumentalizing users' brains, hands, mouths, ears and speech, the Internet and platforms for advertising is part of the alienation of the instruments of labour on Facebook.

Alienation of the instruments of labour also means in the context of Facebook that the users do not own and control the platform. After Facebook's initial public offering, its 12 executive officers and directors controlled together $61.1 \%$ of the class B stock (Facebook Registration Statement, Form S-1). For a class B stock, there are ten votes per share in contrast to the Facebook class A stock, where every share means one vote (ibid.). Other Facebook shareholders include the companies Accel Partners, DST Global Ltd, Elevation Partners, Goldman Sachs, Greylock Partners, Mail.ru Group Ltd, Meritech Capital Partners, Microsoft, Reid Hoffman, T. Rowe Price Associations Inc, Tiger Global Management and Valiant Capital Opportunities LLC (ibid.). These data shows that not the users own Facebook, but rather its directors and some companies. There is a class relationship between users as nonowners and stockowners at the heart of Facebook. The first are Facebook's economic poor who do not control ownership and create the wealth that is controlled and owned by the stockholders. The class of Facebook owners is also politically poor because they do not have the decision power to influence Facebook's rules and design, such as the content of the terms of use and the privacy policy, the privacy settings, the use of advertisements, which user data is sold for advertising purposes, the standard settings (e.g. opt-in or opt-out of targeted ads), required registration data, the placement of commercial and non-commercial content on the screen, etc. In 2009, Facebook introduced a governance page, on which users can discuss changes. It also provides votes about these changes. Facebook says that "if more than $30 \%$ of all active registered users vote, the results will be binding" ${ }^{\prime \prime}$. These votes only concern acceptance or rejection of certain policy changes, but do not cover more fundamental questions such as if advertising should be used or not or who owns Facebook. The $30 \%$ restriction clause seems to have been taken in order to minimise influence of users. Facebook also owns and controls paid employees and technologies (especially servers) that

\footnotetext{
${ }^{7}$ https://www.facebook.com/fbsitegovernance/app_4949752878 (accessed on November 17th, 2009).
} 
are necessary for providing, developing and maintaining the platform as a means of production.

Facebook's objects of labour are human experiences. These experiences are first isolated, private and not connected to each other. On Facebook they can be made public and socially connected with each other. They therefore can be considered to be basic resources and building blocks of the labour conducted by users. By signing up to Facebook, a user agrees to the privacy policy and the terms of use. These documents state that the user agrees that Facebook can use all his/her shared experiences for economic purposes. Thereby users give Facebook the right to use data that represent these experiences for accumulating capital. The experiences are still stored in the users' brains and not detachable from them because knowledge is a good that is not used up in consumption and by being shared. But in economic terms, Facebook gains the right for using representations of these experiences that are stored on the platform for capital accumulation. This means that the users lose control of how and what for their social media activities are economically utilized. Loosing this control also means that Facebook gains the right to monitor all activities of its users and to use the resulting data for economic ends. The legal statements that enable Facebook to control users' data alienate the users from the control of the experiences that they share online. They are alienated through a legally binding agreement. These statements are the privacy terms and the terms of use that e.g. grant Facebook the following rights: "We use the information we receive to deliver ads and to make them more relevant to you. This includes all of the things you share and do on Facebook, such as the Pages you like or key words from your stories, and the things we infer from your use of Facebook" (Facebook Data Use Policy, version from June $8,2012^{8}$ ). "For content that is covered by intellectual property rights, like photos and videos (IP content), you specifically give us the following permission, subject to your privacy and application settings: you grant us a non-exclusive, transferable, sublicensable, royalty-free, worldwide license to use any IP content that you post on or in connection with Facebook (IP License)" (Facebook Statement of Rights and Responsibilities, version from June $8,2012^{9}$ ).

Facebook's product of labour is the result of a process, in which the Facebook platform and human brains as instruments are used for organising human experiences in such a way that data that represents individual and social experiences and that is available publicly or to a defined social group is created as use-value that satisfies the users' needs of making parts of their lives visible to others, communication and co-operation. Examples are that a user has certain ideas that form the object of labour and then publishes them on his/her Facebook profile or another user's wall, whereby they become a product of her/his online work, i.e. a use-value that satisfies the social needs of a community. Another example is that a user has created an image or video that s/he stores on his/her hard disk. This object becomes a usevalue if the user uploads it to Facebook. Another user has certain ideas in his/her head. They represent his/her experiences. If s/he shares them on Facebook by sending a message to friends, the ideas become a use-value for others. Processes such as updating profiles, uploading content, communicating with others are concrete work process that create products that satisfy the informational, communicative and social needs of human groups.

Marx argued that in capitalism labour has at the same time an abstract and a concrete dimension; it creates value and use-values. This means that the products that are created by Facebook users do not just satisfy the users' human needs, but also serve Facebook's profit interests. Facebook turns personal profile data, usage behaviour data from the Facebook platform and other platforms, social network data and content data (images, videos, messages, postings) into data commodities. This means that the use-values that Facebook users create are at the same time commodities that Facebook offers for sale on a market. Facebook usage is work (concrete labour) and labour (abstract labour) at the same time: it generates use-values and economic value. Facebook usage is the connection of a work and a valorisation process. Human subjectivity and human sociality is put to use for capital accu-

\footnotetext{
${ }^{8}$ https://www.facebook.com/full_data_use_policy (accessed on November 18, 2012)

9 https://www.facebook.com/legal/terms (accessed on November 18, 2012)
} 
mulation. All online time of a user is productive work time: it is permanently monitored and stored and packaged together with similar users' data into a data commodity that is offered for sale to advertising clients. The creation of this data commodity not only is based on all time the involved users spend on Facebook, but also the work time of those who are employed in Facebook's advertising department. Data commodities are packaged in such a form that they represent specific user groups with certain demographic characteristics and interests. They are offered to advertising clients, who by purchasing the commodity obtain as a use-value the possibility to present targeted advertising messages to the defined user group. Facebook first controls the data commodity as a use-value, but is only interested in its exchange value, i.e. the money sum it can obtain by selling it. In the sales process, Facebook exchanges use-value for money and the advertising clients obtain use-value by paying money.

It is important to note that Facebook users create two differing use-values by the same digital work: communication and public visibility as their own needs and the possibility that they are confronted with targeted ads. We can therefore speak of the double character of Facebook's use-value: on the one hand, users produce use-values for themselves and others, they create a social relation between users and public visibility. On the other hand, users produce use-values for capital, i.e. targeted advertising space for the advertising industry. For Facebook, both use-values are instrumental for achieving exchange value, i.e. selling to the advertising industry what it wants (ad space) and what is produced by the users. The dual character of use-value stems from the circumstance that the Facebook product/usevalue is informational: it can be exchanged with money and at the same time stay under the control of the users. This double character of the use-value makes the Facebook product a peculiar product: it serves users' own social needs and the commercial needs of advertisers. At the same time, the commercial use-value is first controlled by Facebook and enables the exchange value character and commodification of user data. Information has a peculiar character: "The problem with cultural and informational goods is that, because their use value is almost limitless (they cannot be destroyed or consumed by use) it is extremely difficult to attach an exchange value to them" (Garnham 1990, 38).

Value on Facebook means the average time that users spend on the platform. The law of value on Facebook means that the more time a certain group spends on the platform, the more valuable the corresponding data commodity gets (see Fuchs 2012a, b). A group that on average spends a lot of minutes per day on Facebook (e.g. the group of those aged 15-25) compared to another group (e.g. the group of those aged 75-85) constitutes a more valuable data commodity because a) it has a higher average labour/online time per day that generates more data that can be sold and $b$ ) it spends more time online, during which targeted ads are presented to this group.

Alienation of digital labour concerns labour power, the object and instruments of labour and the created products. Figure 5 summarises this manifold alienation process in the case of Facebook. 
Alienation from the product of labour:

Private control of monetary profit

(dual use-value, inverse commodity fetish)

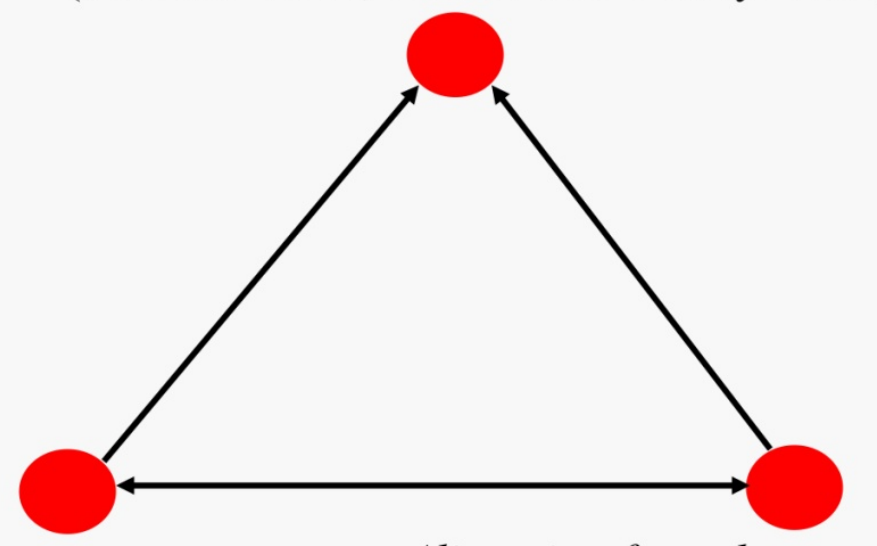

Alienation of labour power

by social violence: Coercion

by isolation and social disadvantages

Alienation from the means of production Object of labour: Instruments of labour: Human experiences private ownership of come under capital's platforms, social media control ideologies

Figure 5: The alienation of digital labour

Marx argued that commodities have an ideological character that he termed the fetish character of the commodity: "The mysterious character of the commodity-form consists therefore simply in the fact that the commodity reflects the societal characteristics of men's own labour as objective characteristics of the products of labour themselves, as the socio-natural properties of these things. Hence it also reflects the social relation of the producers to the sum total of labour as a social relation between objects, a relation which exists apart from and outside the producers" (Marx 1867, 164f). This means that the social relations that form a commodity are not visible in the commodity itself as it presents itself to the consumer.

In the world of digital labour, the fetish character of the commodity takes on an inverted form. We can speak of an inverse fetish character of the social media commodity. The commodity character of Facebook data is hidden behind the social use-value of Facebook, i.e. the social relations and functions enabled by platform use. The inverse fetish of Facebook is typically expressed in statements like "Facebook does not exploit me because I benefit from it by connecting to other users". The object status of users, i.e. the fact that they serve the profit interests of Facebook, is hidden behind the social networking enabled by Facebook. The impression that Facebook only benefits users socially is one-sided because it forgets that this social benefit, the social relations and the obtained visibility, are at the heart of the commercial and corporate side of Facebook, its exchange-value and commodity dimension. Exchange-value gets hidden in use-value; the object side of Facebook hides itself in social relations. The object side of Facebook is grounded in social relations between Facebook, ad clients and users: the exchange relation between Facebook and advertisers on the one hand and coupled to it the advertising relation between advertisers and users. Both relations are necessary for creating profit for both Facebook and the advertisers. These commercial relations do not immediately present themselves to the users, who mainly see the relationships between themselves and other users. The commercial relations that constitute the commodity side of Facebook are hidden behind the social relations between users. Facebook takes 
advantage of its inverse fetish character by presenting itself as organisation that is about sharing and social relations and not about profit.

The discussion shows that there is a class relation between Facebook and its users that constitutes a process of economic exploitation. Facebook is rich in data about its users; it is one of the largest data controllers in the world. It is also rich in the sense that it generates profit from selling these data as commodities. The users appear to primarily benefit from Facebook usage, to become richer in social relations by this use. But their poverty is hidden behind the appearance of social wealth. They are the online poor because they lack the freedom to enter online relations that are not controlled by capital (the poverty of digital labour power: almost the entire Internet is controlled by companies), they lack the ownership and control of corporate online platforms (poverty in relation to the instruments of labour), they lack control over expressing their experiences online independently from capital (poverty in relation to the objects of labour) and they finally lack the ownership of the data commodities they create and the monetary profit that is thereby generated (poverty in relation to the products of labour). This manifold poverty of the digital working class is at the same time the source of wealth: they are the producers of online wealth that is appropriated by capital: the online time that they spend on platforms is productive work and labour time that is valorised and produces money capital that is created, but not owned by the users. The class of the few (the owners of Facebook) benefits at the expense of the class of the many (the users of Facebook). The fact that users are the source of online wealth enables them in principle to overcome their own poverty by becoming the collective master of their collective wealth.

Facebook labour creates commodities and profits. It is therefore productive work. It is however unpaid work and in this respect shares characteristics of other irregular work forces, especially houseworkers and slaves, who are also unpaid. At the same time, Facebook users are facing quite different working conditions in the respect that houseworkers' activities are predominantly involving care work, sexual work and exhausting physical work and that slaves are the private property of slave masters, by whom they can be killed if they refuse work. What these work types however share is the characteristic that the workers are all unpaid and as unpaid workers create more surplus value and profit than in a situation, in which their labour would be conducted by regular labour that is paid. $100 \%$ of their labour time is surplus labour time, which allows capitalists to generate extra-surplus value and extra-profits.

Antonio Negri uses the term "social worker" for arguing that there is a broadening of the proletariat - "a new working class" that is "now extended throughout the entire span of production and reproduction" (Negri 1982/1988, 209). He here takes up Marx's idea of the collective worker that forms an aggregated and combined work force, is heterogeneous and forms a whole of singularities that is necessary for creating profit. Negri (1971/1988) first developed this concept in a reading of Marx's "Fragment on Machines" in the Grundrisse. He argued that the main contradiction of capitalism is that money is the specific measure of value, while labour with the development of the productive forces acquires an increasingly social character and so questions value. The socialisation of labour would have resulted in the "emergence of a massified and socialised working class" (Negri 1971/1988, 104). The notion of the socialised working class was later developed into the concept of the social worker (Negri 1982/1988) that emerged by a reorganisation of capitalism that dissolved the mass worker that had been characterised by Taylorism, Fordism, Keynesianism and the plannerstate (Negri 1982/1988, 205). The social worker signifies "a growing awareness of the interconnection between productive labour and the labour of reproduction" (Negri 1982/1988, 209 ), the emergence of "diffuse labour" (=outsourced labour, Negri 1982/1988, 214) and mobile labour (=labour flexibility, Negri 1982/1988, 218).

The advantage of the concept of the social worker, which is a reformulation of Marx's notion of the collective worker in the context of informational and post-Fordist capitalism, is that it allows us to consider also irregular and unpaid workers (houseworkers, slaves, precarious workers, migrant workers, education workers, public service workers, the unemployed, etc) as productive labourers (Fuchs 2010a).

Negri goes however so far as to say that "labour time" as a consequence of this tendency "becomes increasingly irrelevant in the context of a full socialisation of the productive ma- 
chine" (Negri 1971/1988, 100). This is just another formulation for saying that the law of value ceases to exist - it is "in the process of extinction" (Negri 1971/1988, 148). As a consequence, Negri assumes that communism is near: "communism is the present-day tendency, an active force operating in the here and now" (Negri 1971/1988, 112). The law of value operates as long as capitalism exists: it does not stop operating due to the emergence of social or knowledge work and has in fact not stopped operating in all the years that have passed since Negri first formulated this idea. The labour time of a specific part of the social worker can perfectly be measured: it is the average number of hours of unpaid work performed by a specific group or overall in a society. That the socialisation of work increases due to the rise of productivity means that the time needed for producing certain goods has historically decreased. High productivity is a precondition of communism, but it is not communism itself and does not automatically lead to communism. There are communist potentials within capitalism, communism can however only be established by struggles.

Theories of cognitive capitalism reflect Negri's approach (Vercellone 2007; 2010; Boutang 2012). Cognitive capitalism is seen as an emerging stage of capitalism that has succeeded mercantile and industrial capitalism (Vercellone 2007, 14-17; Boutang 2012, 50). "The mode of production of cognitive capitalism [...] is based on the cooperative labour of human brains joined together in networks by means of computers" (Boutang 2012, 57). Exploitation in cognitive capitalism is for Boutang organised differently from industrial capitalism (Boutang 2012, 94) since "the object of accumulation consists mainly of knowledge, which becomes the basic source of value, as well as the principal location of the process of valorisation" (Boutang 2012, 57).

Proponents of this kind of theory assume that in cognitive capitalism not capital organises the social cooperation of labour, like it was the case in the traditional factory, but cooperation is organised beyond the factory walls and is increasingly independent from capital's direct control. Capital does not itself apply the means of production and does not organise the production process directly. Theorists of cognitive capitalism therefore qualify real subsumption of work under capital as a new historic epoch in capitalist societies - the epoch of general intellect or the formation of cognitive capitalism. Vercellone argues that capital "was becoming external in relation to the sphere of production and, like land ownership, capital ownership was extracting surplus value whilst no longer exercising any function in the organization of labor" $(2010,100)$. These theorists argue that the mode of how surplus is appropriated has changed. Whereas Marx sees rent as a redistribution of externally generated value. Theorists of cognitive capitalism hold the thesis of profit-becoming-rent (Vercellone 2010) that is quite contested in Marxist theory (e.g. Jeon 2010, Caffentzis 2013).

It is hard to see in our context why Facebook capital would be external to the sphere of production and "no longer exercising any function in the organization of labor" (Vercellone $2010,100)$. On the contrary we have already argued that Facebook capital actively organises, shapes and controls the digital labour process and alienates the labour force, the means of production and the labour product. Generally speaking cognitive capitalism theory tends to assume that cognitive labour and therefore labour on Facebook has already become work simply due to its cognitive quality and thereby rarely considers the social relations within which this work/labour is organized.

Notwithstanding these limits of Negri's theory and the cognitive capitalism approach that builds on his approach, the logical consequence of the concept of the social or collective worker is that one is exploited and productive if one is part of the collective worker that produces commodities. Digital labour on Facebook and other corporate digital media is enabled by and connected to an entire value and commodity chain and global sphere of exploitation that constitutes the ICT industry (Huws 2010). The knowledge economy is by no way dematerialised (Huws 1999/2003). It is a matter of ongoing research and dispute how digital labour is exactly connected to other valorization processes and how the value dimension of digital labour can best be understood (Fuchs 2010, Arvidsson and Colleoni 2012, Fuchs 2012b; Fine, Jeon and Gimm 2010; Böhm, Land and Averungen 2012). The reality of ICTs today is enabled by the existence of a plenitude of exploited labour, such as the slave-labour of people of colour in Africa who extract minerals, out of which ICT hardware is produced, the high- 
ly exploited labour of industrial workers in China and other countries that assembles hardware tools, precarious call centre work, dangerous eWaste labour in developing countries, etc (Fuchs 2014). Also the labour of low paid software engineers and knowledge workers in developing countries as well as the activities of a labour-aristocracy of highly paid and highly stressed software engineers in Western software companies is needed (Fuchs 2014). There are also accountants, marketing and public relations employees and other circulation workers who work on capturing, analysing, and selling the prosumer commodity to the advertising industry, which in turn employs workers in advertising agencies and companies' marketing divisions. The labour that produces the commodities.that are advertised on Facebook and other platforms is also connected to digital labour on social media.

Although the different forms of labour involved vary greatly in terms of working conditions, the degree of exploitation and alienation as well as the workers' self-understandings, identities and class consciousness, they are all interlinked. This is increasingly so since globalisation and primitive accumulation processes are ongoing. Knowledge workers of the world therefore are connected by the circumstance that they are all exploited by capital. The question that therefore arises is if the collective worker and the social knowledge proletariat of the world will organise politically and become a class-for-itself that struggles against capitalism.

Capitalism connects labour and play in a destructive dialectic. Traditionally, play in the form of enjoyment, sex, and entertainment was in capitalism only part of spare time, which was unproductive and separate from labour in time. Sigmund Freud (1961) argued that the structure of drives is characterized by a dialectic of Eros (drive for life, sexuality, lust) and Thanatos (drive for death, destruction, aggression). Humans would strive for the permanent realization of Eros (pleasure principle), but culture would only become possible by a temporal negation and suspension of Eros and the transformation of erotic energy into culture and labour. Labour would be a productive form of desexualization - the repression of sexual drives. Freud speaks in this context of the reality principle or sublimation. The reality principle sublates the pleasure principle; human culture sublates human nature and becomes man's second nature. Marcuse (1955) connected Freud's theory of drives to Marx's theory of capitalism. He argued that alienated labour, domination, and capital accumulation have turned the reality principle into a repressive reality principle - the performance principle: alienated labour constitutes a surplus-repression of Eros - the repression of the pleasure principle takes on a quantity that exceeds the culturally necessary suppression. Marcuse connected Marx's notions of necessary labour and surplus labour/value to the Freudian drive structure of humans and argued that necessary labour on the level of drives corresponds to necessary suppression and surplus labour to surplus-repression. This means that in order to exist, a society needs a certain amount of necessary labour (measured in hours of work) and hence a certain corresponding amount of suppression of the pleasure principle (also measured in hours). The exploitation of surplus value (labour that is performed for free and generates profit) would mean not only that workers are forced to work for free for capital to a certain extent, but also that the pleasure principle must be additionally suppressed.

"Behind the reality principle lies the fundamental fact of Ananke or scarcity (Lebensnot), which means that the struggle for existence takes place in a world too poor for the satisfaction of human needs without constant restraint, renunciation, delay. In other words, whatever satisfaction is possible necessitates work, more or less painful arrangements and undertakings for the procurement of the means for satisfying needs. For the duration of work, which occupies practically the entire existence of the mature individual, pleasure is 'suspended' and pain prevails" (Marcuse 1955, 35). In societies that are based on the principle of domination, the reality principle takes on the form of the performance principle. Domination "is exercised by a particular group or individual in order to sustain and enhance itself in a privileged situation" (Marcuse 1955, 36). The performance principle is connected to surplus-repression, a term that describes "the restrictions necessitated by social domination" (Marcuse 1955, 35). Domination introduces "additional controls over and above those indispensable for civilized human association" (Marcuse 1955, 37).

Marcuse (1955) argues that the performance principle means that Thanatos governs humans and society and that alienation unleashes aggressive drives within humans (repressive 
desublimation) that result in an overall violent and aggressive society. Due to the high productivity reached in late-modern society, a historical alternative would be possible: the elimination of the repressive reality principle, the reduction of necessary working time to a minimum and the maximization of free time, an eroticization of society and the body, the shaping of society and humans by Eros, the emergence of libidinous social relations. Such a development would be a historical possibility - but one incompatible with capitalism and patriarchy.

Luc Boltanski and Éve Chiapello (2007) argue that the rise of participatory management means the emergence of a new spirit of capitalism that subsumes the anti-authoritarian values of the political revolt of 1968 and the subsequently emerging New Left such as autonomy, spontaneity, mobility, creativity, networking, visions, openness, plurality, informality, authenticity, emancipation, and so on, under capital. The topics of the movement would now be put into the service of those forces that it wanted to destroy. The outcome would have been "the construction of the new, so-called 'network' capitalism" (Boltanski and Chiapello 2007, 429 ) so that artistic critique - that calls for authenticity, creativity, freedom and autonomy in contrast to social critique that calls for equality and overcoming class (37f) - today "indirectly serves capitalism and is one of the instruments of its ability to endure" (490). Play labour is a new ideology of capitalism: objectively alienated labour is presented as creativity, freedom and autonomy that is fun for workers. That workers should have fun and love their objective alienation has become a new ideological strategy of capital and management theory. Facebook labour is an expression of play labour ideology as element of the new spirit of capitalism.

Gilles Deleuze (1995) has pointed out that in contemporary capitalism, disciplines are transformed in such a way that humans increasingly discipline themselves without direct external violence. He terms this situation the society of (self-)control. It can for example be observed in the strategies of participatory management. This method promotes the use of incentives and the integration of play into labour. It argues that work should be fun, workers should permanently develop new ideas, realize their creativity, enjoy free time within the factory, etc. The boundaries between work time and spare time, labour and play, become fuzzy. Work tends to acquire qualities of play, and entertainment in spare time tends to become labour-like. Working time and spare time become inseparable. At the same time work-related stress intensifies and property relations remain unchanged. The exploitation of Internet users by Facebook (and other Internet companies) is an aspect of this transformation. It signifies that private Internet usage, which is motivated by play, entertainment, fun, and joy - aspects of Eros - has become subsumed under capital and has become a sphere of the exploitation of labour. It produces surplus value for capital and is exploited by the latter so that Internet corporations accumulate profit. Play and labour are today indistinguishable. Eros has become fully subsumed under the repressive reality principle. Play is largely commodified, there is no longer free time or spaces that are not exploited by capital. Play is today productive, surplus value generating labour that is exploited by capital. All human activities, and therefore also all play, tends under the contemporary conditions to become subsumed under and exploited by capital. Play as an expression of Eros is thereby destroyed, human freedom and human capacities are crippled. On Facebook, play and labour converge into play labour that is exploited for capital accumulation. Facebook therefore stands for the total commodification and exploitation of time - all human time tends to become surplus-value generating time that is exploited by capital. Table 4 summarizes the application of Marcuse's theory of play, labour and pleasure to Facebook and social media. 


\begin{tabular}{|c|c|c|c|}
\hline $\begin{array}{l}\text { Essence of } \\
\text { human de- } \\
\text { sires: }\end{array}$ & $\begin{array}{l}\text { Reality principle } \\
\text { in societies with } \\
\text { scarcity }\end{array}$ & $\begin{array}{l}\text { Repressive reality } \\
\text { principle in classi- } \\
\text { cal capitalism }\end{array}$ & $\begin{array}{l}\text { Repressive reality principle in capitalism } \\
\text { in the age of Facebook }\end{array}$ \\
\hline $\begin{array}{l}\text { immediate } \\
\text { satisfaction }\end{array}$ & $\begin{array}{l}\text { delayed satisfac- } \\
\text { tion }\end{array}$ & delayed satisfaction & Immediate online satisfaction \\
\hline pleasure & $\begin{array}{l}\text { restraint of pleas- } \\
\text { ure }\end{array}$ & $\begin{array}{l}\text { leisure time: pleas- } \\
\text { ure, work time: re- } \\
\text { straint of pleasure, } \\
\text { surplus repression } \\
\text { of pleasure }\end{array}$ & $\begin{array}{l}\text { Collapse of leisure time and work time, leisure } \\
\text { time becomes work time and work time lei- } \\
\text { sure time, all time becomes exploited, online } \\
\text { leisure time becomes surplus value- } \\
\text { generating, wage labour time = surplus re- } \\
\text { pression of pleasure, play labour time = sur- } \\
\text { plus value generating pleasure time }\end{array}$ \\
\hline joy (play) & Toil (work) & $\begin{array}{l}\text { leisure time: joy } \\
\text { (play), work time: toil } \\
\text { (work) }\end{array}$ & $\begin{array}{l}\text { play labour: joy and play as toil and work, toil } \\
\text { and work as joy and play }\end{array}$ \\
\hline receptiveness & productiveness & $\begin{array}{l}\text { leisure time: recep- } \\
\text { tiveness, work time: } \\
\text { productiveness }\end{array}$ & $\begin{array}{l}\text { Collapse of the distinction between leisure } \\
\text { time/work time and receptive- } \\
\text { ness/productiveness, total commodification of } \\
\text { human time }\end{array}$ \\
\hline $\begin{array}{l}\text { absence of } \\
\text { repression of } \\
\text { pleasure }\end{array}$ & $\begin{array}{l}\text { repression of } \\
\text { pleasure }\end{array}$ & $\begin{array}{l}\text { leisure time: ab- } \\
\text { sence of repression } \\
\text { of pleasure, work } \\
\text { time: repression of } \\
\text { pleasure }\end{array}$ & $\begin{array}{l}\text { play labour time: surplus value generation } \\
\text { appears to be pleasure-like, but serves the } \\
\text { logic of repression (the lack of ownership of } \\
\text { capital) }\end{array}$ \\
\hline
\end{tabular}

Table 4: Pleasures in four modes of society (human essence, society with scarcity, classical capitalism, capitalism in the age of Facebook), based on a table from: Marcuse 1955, 12.

\subsection{Digital Work and Communism}

Capitalist companies control the Internet. If one takes a look at the list of the 100 most frequently accessed web platforms in the world (http://www.alexa.com/topsites), then only few exceptions can be found: Wikipedia and BBC Online. Wikipedia is operated by a noncommercial non-profit organisation, the Wikimedia Foundation. It funds its activities by donations, does not have advertisements and does not sell commodities. The BBC is a British UK public service media provider that is predominantly funded by the licence fee, but on its international broadcasting and web outlets also sells advertisements for co-funding its domestic UK operations10. This means that most web usage is digital labour that creates commodities and profit that is owned by private companies. The Internet is largely dominated by the exploitation of digital labour. The question that now arises is how the Internet can be decommodified. We have ideas about how public service media look like in the realm of broadcasting, whereas the idea of the public good is much more uncommon in the online world because the latter is so much grounded in commercial and corporate values and control.

An important analytical and political question is if users are satisfied with the labour they perform for Facebook and other commercial social media and happily accept a trade-off between personal data commodification and access to corporate platforms without payment. This question cannot be theoretically decided, but rather only by social research. Research results suggest that users are rather critical of targeted advertising. In a survey that we conducted together with colleagues in the research project "Social networking sites in the surveillance society" (see http://sns3.uti.at), $82.1 \%$ of the respondents said they do not want to have targeted advertising on the websites they visit $(\mathrm{N}=3558)$.

\footnotetext{
10 "International users may see advertisements on some BBC Online Services. These advertisements are provided and delivered by the BBC's commercial arm, BBC Worldwide Limited" (Terms of Use of BBC Online Services - Personal Use, http://www.bbc.co.uk/terms/personal.shtml).
} 
A counter-argument one sometimes hears is that targeted ads are not privacy-invasive because they only aggregate data and do not give advertisers direct access to personal data. Our study also showed that $59 \%$ say that they do not wish to have targeted ads on Facebook even if the data are not shared with advertisers $(\mathrm{N}=3558) .94 .7 \%$ say they oppose targeted ads on other platforms for which Facebook provides personal data to advertisers $(\mathrm{N}=3948)$.

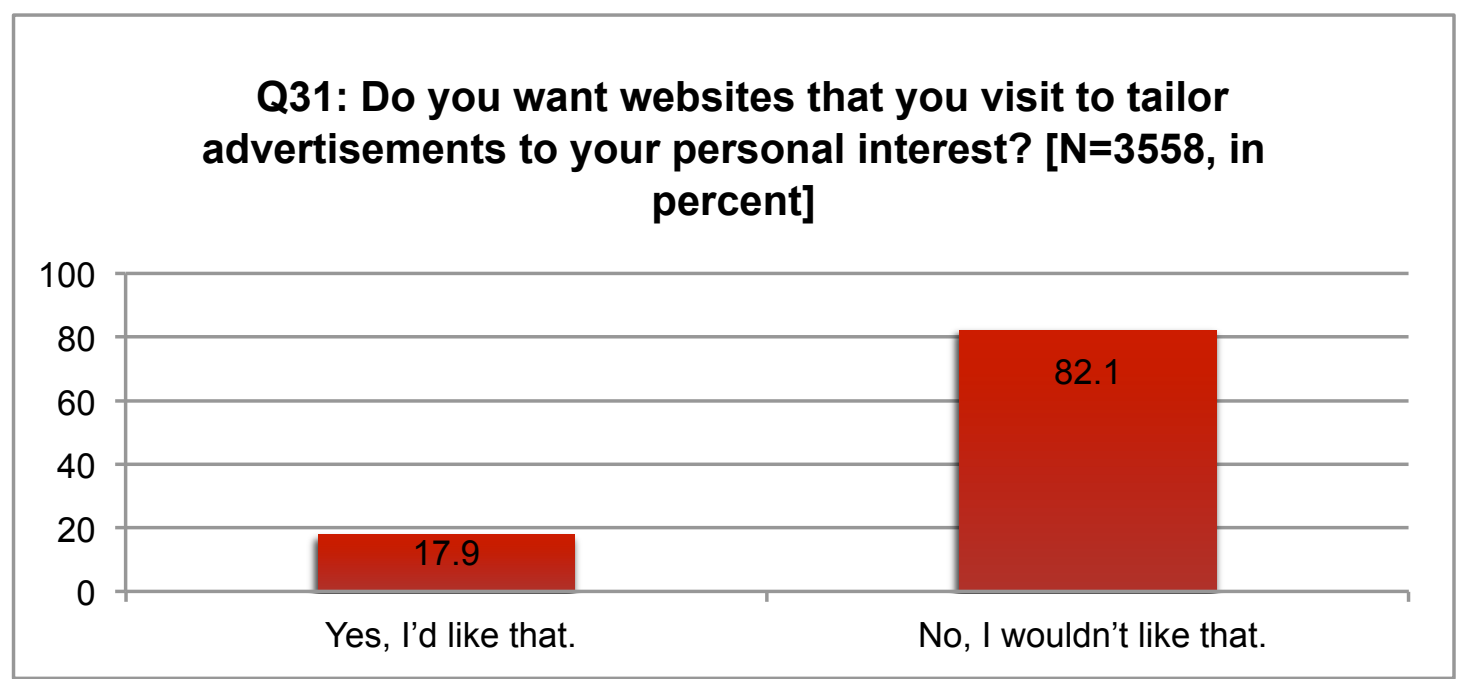

Figure 6: Users attitudes towards targeted advertisements in the research project "Social networking sites in the surveillance society" (http://sns3.uti.at)

\begin{tabular}{|c|c|c|c|}
\hline \multicolumn{4}{|c|}{ Is it ok for you that based on your Facebook profile data... (N=3948) } \\
\hline & Yes & No & I do not know \\
\hline $\begin{array}{l}\text { ads on Facebook are targeted to your } \\
\text { personal interests without Facebook } \\
\text { providing these data to external advertis- } \\
\text { ing clients }\end{array}$ & $\begin{array}{c}1235 \\
(31.3 \%)\end{array}$ & $2331(59.0 \%)$ & $382(9,7 \%)$ \\
\hline $\begin{array}{l}\text { ads on other websites are targeted to } \\
\text { your personal interests by Facebook } \\
\text { providing these data to external advertis- } \\
\text { ing clients }\end{array}$ & $73(1.8 \%)$ & $3738(94.7 \%)$ & $137(3.5 \%)$ \\
\hline
\end{tabular}

Table 5: Users 'attitudes towards targeted advertisements in the research project "Social networking sites in the surveillance society" (http://sns3.uti.at)

In a European-wide survey, $54 \%$ of the respondents said that they feel uncomfortable about targeted advertising (see figure 7). Such data show that one cannot assume that users are happy about a trade-off between data commodification and "free" access and that they are rather critical of such a trade-off model and that there is a need for discussing alternatives to targeted advertising and corporate Internet platforms. 
QB21. As you may know, some Internet companies are able to provide free search engines or free e-mail accounts thanks to the income they receive from advertisers trying to reach users on their websites. How comfortable are you with the fact that those websites use information about your online activity to tailor advertisements or content to your hobbies and interests?

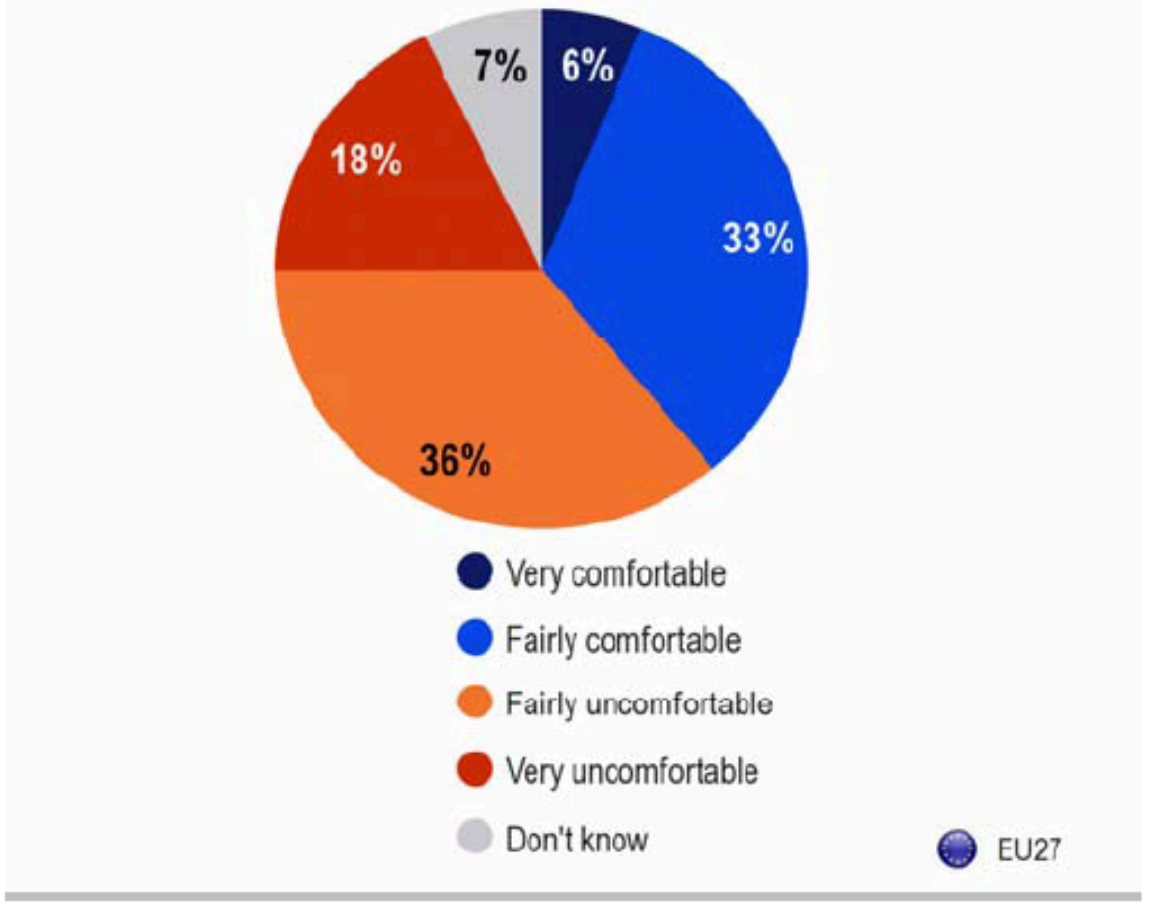

Base: Internet users ( $66 \%$ of whole sample)

Figure 7: European Internet users' attitudes towards targeted advertising (data source: Special Eurobarometer 359: Attitudes on Data Protection and Electronic Identity in the European Union)

A humanization of the Internet requires a communist Internet in a communist society, an Internet that is not controlled by the logic of capital and by private profit making, but an Internet that is controlled by all users, benefits all users and is grounded in the logic of the information gift that is inexhaustible by consumption and accessible to all without payments, the logic of common access to technology and knowledge, common production, common ownership, common control, common interests beyond class, common benefits - the logic of the commons $=$ the reality of communism .

Michael Hardt $(2010,136)$ argues that there are two types of the common: the natural common (earth, land, forests, water, air, minerals, etc) and the artificial common (ideas, language, affects, information, images, knowledge, codes, social relationships, affects). Slavoj Žižek $(2010,212 f)$ draws a distinction between the cultural commons (language, means of communication, education, infrastructures), the commons of external nature (the natural environment) and the commons of internal nature (the human being). For Hardt, the commons are "weapons for a communist project" (Hardt 2010, 143) that "escape the boundaries of property" (Hardt 2010, 136), for Slavoj Žižek (2010) the commons justify "the resuscitation of the notion of communism" (Žižek 2010, 213).

Hardt and Žižek's definitions of the commons create the impression that the commons are based on specific inherent qualities of goods, namely that they are not created by single individuals and to a certain extent resist commodification. But the problem of these definitions and the argument that the base on it, namely that communism is grounded in the commons, is that they imply politically that only certain goods should be owned and controlled collectively in a communist society, namely nature, culture, knowledge and general infrastructures. 
So the private property status of other goods is not automatically questioned. For Marx and Engels, communism meant not just the common ownership and control of certain means of production and goods, but the common control of all socially necessary goods. Engels (1847) therefore spoke of communism as "the common utilization of all instruments of production and the distribution of all products according to common agreement - in a word, what is called the communal ownership of goods" and a society, in which "branches of production are operated by society as a whole - that is, for the common account, according to a common plan, and with the participation of all members of society".

Let us take the example of the production of bicycles. A bicycle is different from fresh air and knowledge in the respect that only a limited number of people can consume them at one point of time. It is a good whose consumption is exclusive. Nonetheless Marx and Engels would argue that bicycles should become a common good in a communist society: their production process should be controlled by the producers, who should also own the instruments and objects of labour, and the results of production - bicycles - would either be made available publicly to all so that one can use a bike whenever one needs one or everyone would get his/her own bicycle for free so that everybody has one. The difference that knowledge has in contrast to bicycles is that it is more difficult to exclude others from consumption: knowledge has no wear and tear, it can in principle be used at the same point of time by an endless number of consumers and it can easily and quickly be copied. For turning it into a commodity, legal rules that are carried out by state apparatuses and enforce the commodity status and outlaw copying are needed. Nonetheless many goods, not just culture, information, nature and infrastructures, can be turned into common goods (and vice-versa into commodities).

On Facebook and other social media, the created content is commodified, but this commodification does not result in the full separation of the content from the producers, but rather in the users' separation from the economic usage rights and the monetary profits gained with these rights. The specific characteristics of knowledge as peculiar good that it is not used up by consumption, can be simultaneously used by many and can be easily and endlessly copied make it on the one hand a good that can be more easily turned into a common property than bicycles, but at the same time can create the (inverse) ideological fetishism that commodification of knowledge on platforms such as Facebook is not problematic because one can still access one's own knowledge and does not lose access to it by commodification. Knowledge at the same time displays communist germs and anti-communist ideology. Commons are not specific goods, but rather any good can be turned into a private property, just like it can become a common good:

- Subject: Labour power is not a commodity, but rather productivity is so high that there are well-rounded individuals that are not facing scarcity and necessity and that freely chooses their activities.

- Means of production: The objects of labour are owned and controlled in common. Means of production: The instruments of labour are owned and controlled in common. Subject-object: The work products are commonly controlled and accessible to all people in society without payment .

- In a communist society, the entire work process is jointly controlled.

Figure 8 visualises the dimensions of a common good in a communist society. 


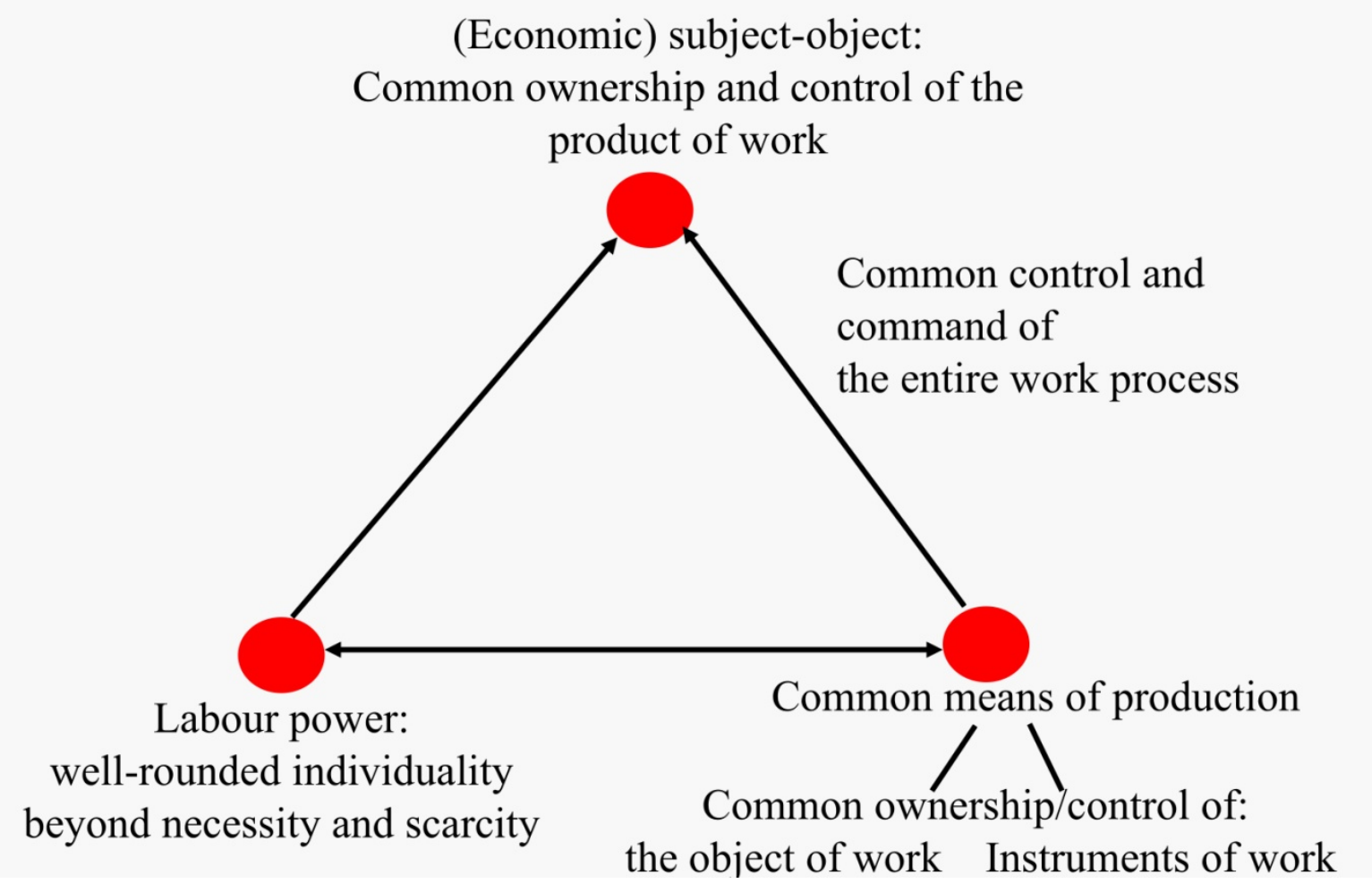

Figure 8: Dimensions of the commons

A communist/commons-based social networking platform therefore has the following dimensions:

- Subject: Usage does not have an instrumental character, no commodity is created by it, only use-values that satisfy social needs.

- Means of production: Experiences are seen as something that is worth sharing with others. People feel no necessity to keep their experiences apart from others and as a private secret. The idea of keeping knowledge hidden from others and private is less important. The concept and reality of privacy do not vanish, but take on a different role. The idea of public communication becomes a crucial element of society.

- Means of production: A communist social medium is a non-commercial non-profit organisation that is controlled and owned by all its users.

- Subject-object: The products of online work have no commodity character, they serve purely social needs: that people inform themselves, communicate and collaborate with each other.

In a communist society, digital labour becomes digital work. The use-value created is informational: digital work creates shared cognition, communication (social relations) and cooperation (communities, collaborative work). Information's commodity character is abolished and it becomes a truly common good. Figure 9 visualises the dimensions of a communist Internet platform in a communist society. Only a commons-based Internet is a truly and fully "social medium" in the sense that the subject, objects and subject-objects of work become controlled by society as a whole and stop being owned by private individuals who accumulate capital. 
(Economic) subject-object:

Commonly shared and controlled cognition, communications, co-operation

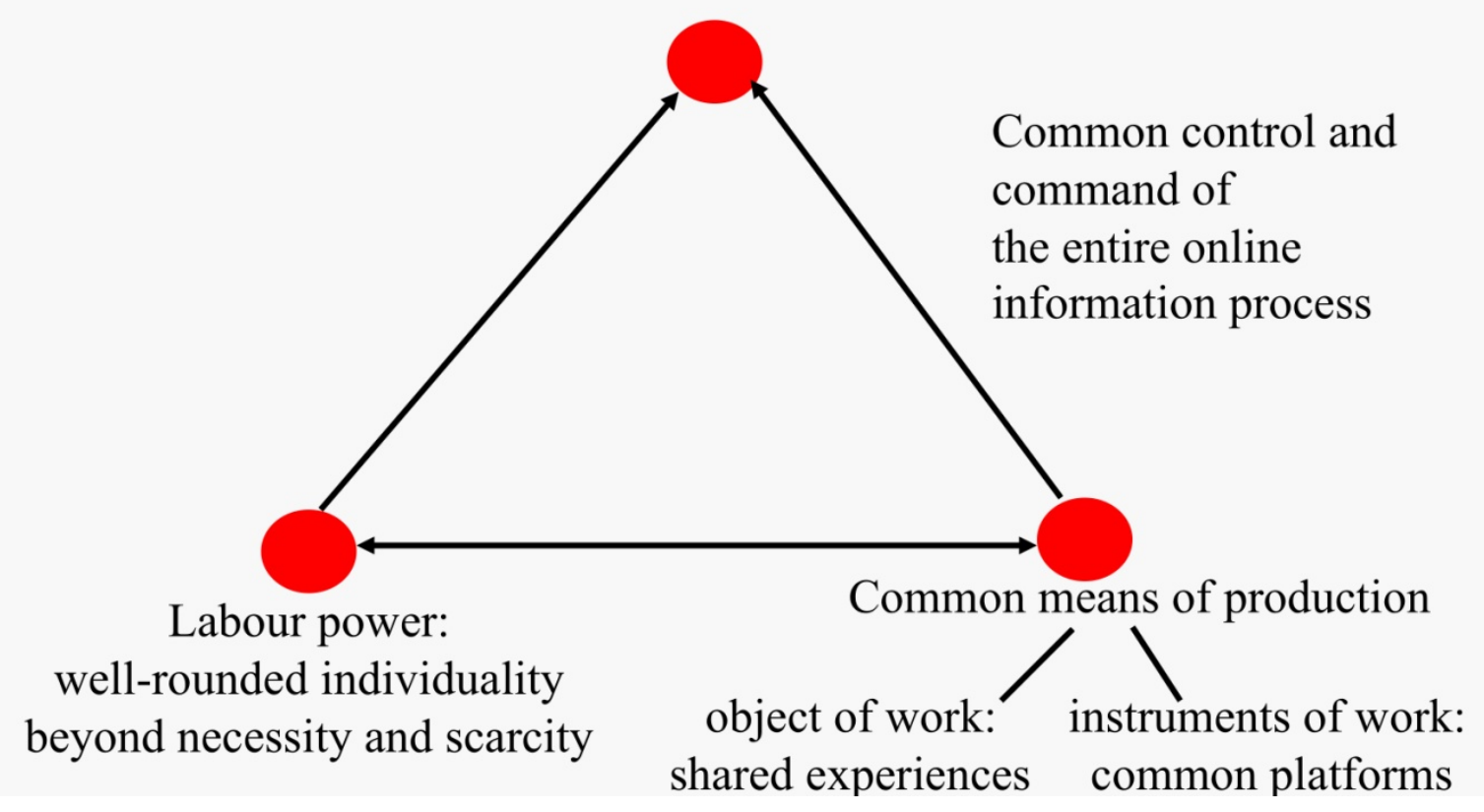

Figure 9: Dimensions of a commons-based Internet

Attempts at establishing non-commercial alternatives to Facebook exist. Examples are the social networking sites Diaspora* (Sevignani 2012), Occupii and N-1. Diaspora* describes itself as "the community-run, distributed social-network"11. Occupii is a non-commercial SNS created by the Occupy movement that serves the purpose of networking activists. $\mathrm{N}-1$ is a non-commercial SNS that describes itself as "social networks by the people for the people" and explains its existence by saying that "the master's tools will never dismantle the master's house"12. Usage of these platforms is not digital labour, but digital work: online activity creates use-value (communication, social relations, publicity), but no commodities. These platforms are shaped by the logic of the commons and not by the logic of capital and commodities. They are foundations of a communist Internet. A communist Internet is characterised by common access for all, common ownership, is a common space of communication, provides the common capacity to produce and share knowledge, is a common space for the cocreation of shared meanings (co-operation), is a common space for political debate, a common space for co-forming collective values and identities and a common space for struggles against the colonization of the commons and communism (Fuchs 2011, chapter 9).

However, alternative social media currently exist within capitalism, which means that certain goods necessary for the operation (especially servers, domain names and bandwidth) have to be purchased as commodities. The employed software is free software developed in common. But within capitalism, free software development requires time and time is a scarce resource. So many free software developers have a day job for earning a living and contribute to software development voluntarily and unpaid during their spare time. Facebook and other commercial platforms in contrast have a revenue stream that stems from Internet prosumer commodification, which allows them to employ software engineers and other operational personnel, to buy servers and other goods that are necessary for operating and to

\footnotetext{
${ }_{11}^{11} \mathrm{https}$ ://www.joindiaspora.com/ (accessed on November 18, 2012).

12 https://n-1.cc/ (accessed on November 18, 2012).
} 
engage in public relations by running ads and campaigns that promote Facebook usage. Platforms like Facebook and Google also have reputational power and political influence because they are huge organisations that control access to a large global user community.

Alternative platforms in contrast depend on donations and voluntary work. Money is the dominant medium of capitalism, as general equivalent of exchange - the general commodity - it can be used for obtaining most other goods. It is the outcome of capitalist production. Those who control and accumulate money power are therefore equipped with a resource that puts them at a strategic advantage. This means that alternative online platforms in capitalism are facing power inequalities that stem from the asymmetric distributions of money and other resources that are inherent in capitalism. Practically this means that alternative platforms have less money and fewer users than Facebook. Facebook had around 1,0 billion users in November $2012^{13}$. In contrast, Diaspora* ${ }^{* 14}$ had at the same time around 90000 users, Occupii 5303 members and N-1 44414 members. This circumstance shows that Facebook controls monetary, reputational and usage power that puts alternative players at a disadvantage and makes it difficult for them to challenge the de-facto monopoly of Facebook in the realm of social networking sites. Using social networking sites is predominantly and to a large degree social labour that is alienated and not social work that focuses on a pure social logic and transcends the private logic of capital accumulation. Using platforms such as Diaspora*, Occupii and $\mathrm{N}-1$ is digital work, but this work is embedded into the unequal political economy of the Internet that is shaped by capitalism.

How can alternatives be strengthened? How can a communist Internet be built? One argument is that Facebook usage should be remunerated, that social media unions should be founded and that the struggle for an online wage is needed. Digital labour creates value, but to a large degree digital labour power is not a commodity. It is unpaid and not sold as a commodity. The failure of social democracy has been that it has since a long time not struggled against the commodity form and for the abolishment of labour, but only for the increase of wages, which does not question the commodification of labour power as such. Labour power can be de-commodified by creating self-managed or public companies that do not follow profit logic. As long as the logic of money exists, such work can be remunerated, but does not create profit in such companies because these are organisations that follow the logic of the public or common good. Once a wage relationship is installed, it is easier to struggle for wage increases than for the establishment of alternative forms of organising work. In the case of Facebook and corporate social media, the non-existence of a wage relationship as well as the circumstance that a mass exodus from a commercial platform to an alternative non-commercial one does not cause disadvantages for users because due to the nature of information as peculiar good that is not used up by consumption and sharing they can transfer their use-values (social connections, visibility) and do not lose any exchange value of their labour power because they are unpaid.

We therefore oppose the idea of paying a wage to users of Facebook, Google and other corporate platforms that exploit unpaid digital labour. We rather argue for establishing and nourishing the existing alternative Internet platforms by user support, donations and public funding. Occupii and N-1 are more political activist platforms, whereas Diaspora* has set out to become an alternative to Facebook. We think that a combined political strategy of class struggle of the digital working class is needed that seeks both breadth and depth: it on the one hand should aim at providing a non-commercial communist alternative to Facebook that attracts a lot of users and in the end results in a collective exodus from Facebook that at once and as a combined act transfers all users to alternative platforms and on the other hand requires the networking of activists as a social movement that challenges class relations. The Occupy movement is a class struggle movement that questions the power of capital. It also makes use of social media and has created its own social media (such as Occupii and the Global Square). Facebook and other corporate social media are part of the 1\%, but are nour-

\footnotetext{
${ }^{13}$ Three month usage access: $43.284 \%$ of all Internet users (alexa.com, accessed on Nov. 18, 2012). Worldwide Internet users: 2,405,518,376 (http://www.internetworldstats.com/stats.htm, accessed on Nov. 18, 2012).

${ }^{14}$ Three month usage access: $0.00376 \%$ of all Internet users (alexa.com, accessed on Nov. 18, 2012)
} 
ished by the digital labour of the $99 \%$. Occupying the Internet requires a communist movement that politicizes the Internet and makes use of its own platforms for networking activists and of existing commercial platforms for reaching out to users and preparing the exodus from corporate platforms as class struggle strategy. The overall goal is the sublation of online alienation, i.e. the self-determination of digital labour power and the common control of online platforms, online experiences and online interactions. We require the transformation of digital labour into digital work. We require a true social media revolution.

\section{Why (Not) to Abolish the Concept of Work?}

Especially Autonomist Marxist and Anarchist thinkers have argued that the concept of work should just like the notion of labour be defined as being coercive as well as essentially capitalist and dominative in nature. A free society would then be a non-work and non-labour society. Table 6 gives an overview of arguments employed by representatives of the anti-work philosophy and the alternative concepts they suggest. The table does not claim completeness of authors and arguments, but rather wants to exemplarily show the existence of arguments employed by anti-work philosophy.

\begin{tabular}{|c|c|c|c|}
\hline Literature & $\begin{array}{l}\text { Argument against } \\
\text { using the term "work" } \\
\text { in a general sense }\end{array}$ & $\begin{array}{l}\text { Alternative concept in } \\
\text { communism }\end{array}$ & $\begin{array}{l}\text { Alternative anthropo- } \\
\text { logical concept }\end{array}$ \\
\hline Gorz (1982) & $\begin{array}{l}\text { Work is waged activity } \\
\text { carried out for and un- } \\
\text { der the command of } \\
\text { others under the com- } \\
\text { mand by others }\end{array}$ & self-determined activity & \\
\hline Negri (1991) & $\begin{array}{l}\text { Marx uses the term } \\
\text { work in the Grundrisse } \\
\text { only as abstract, waged } \\
\text { work }\end{array}$ & self-valorization & \\
\hline Black (1996) & $\begin{array}{l}\text { Work is compulsory } \\
\text { production, Marx was a } \\
\text { productivist }\end{array}$ & play & \\
\hline $\begin{array}{l}\text { Cleaver (2002), } \\
\text { Cleaver (2003) }\end{array}$ & $\begin{array}{l}\text { The work concept did } \\
\text { not exist before capital- } \\
\text { ism; } \\
\text { Marx projects the bour- } \\
\text { geois concept of work } \\
\text { backwards and for- } \\
\text { wards in history; } \\
\text { the assumption that in } \\
\text { a free society everyone } \\
\text { is a worker is an ideol- } \\
\text { ogy used in the Soviet } \\
\text { Union for legitimatizing } \\
\text { forced labour }\end{array}$ & $\begin{array}{l}\text { self-valorization, self- } \\
\text { constitution }\end{array}$ & \\
\hline Weeks (2011) & $\begin{array}{l}\text { A glorification of work } \\
\text { as human endeavour } \\
\text { ideologically legitima- } \\
\text { tizes the work ethic and } \\
\text { the work society that do } \\
\text { not want to abolish but } \\
\text { extend toil }\end{array}$ & antiwork, postwork, life & \\
\hline
\end{tabular}

Table 6: Arguments of Autonomist Marxists and Anarchists against the concept of work 


\subsection{Why Is There a Difference Between Work and Labour and Where Does It Come From?}

A first common strategy is that anti-work theorists define work identical with labour and do not further explore categorical differentiations and reasons why there may be two words for related, but at the same time different phenomena in the English language and other languages. So for example André Gorz $(1982,1)$ writes that work "came into being at the same time as capitalists and proletarians. It means an activity carried out: for someone else; in return for a wage; according to forms and time schedules laid down by the person paying the wage; and for a purpose not chosen by the worker". Kathi Weeks $(2011,14)$ uses the terms labour and work interchangeably for "productive cooperation organized around, but not necessarily confined to, the privileged model of waged labor". Bob Black (1996) defines work as "forced labor, that is, compulsory production". Such definitions a) leave unclear how human activities that in all types of society maintain and are necessary for the existence of humans and society should be termed and b) why exactly labour and work should be equated and why in many languages two words exist for characterizing productive or creative human activity.

Toni Negri argues that in Marx's Grundrisse, work is a specifically capitalist concept: "In the Grundrisse, work appears as immediately abstract labor. We can only understand it and integrate it within theory at this level. Work is abstract in so far as it is only immediately perceptible at the level of the social relations of production. Thus we can only define work on the basis of the relations of exchange and of the capitalist structure of production. We can find no concept of work in Marx that is not that of waged work, of work that is socially necessary to the reproduction of capital, thus no concept of any work to restore, to liberate, to sublimate, only a concept and a reality to suppress" (Negri 1991, 10).

In the Grundrisse, Marx (1857/58b, 611) says that labour as "slave-labour, serf-labour, and wage-labour, [...] always appears as repulsive, always as external forced labour; and not-labour, by contrast, as 'freedom and happiness'". In a free society "labour becomes attractive work, the individual's self-realization". Such work would be social, scientific and general (Marx 1857/58b, 612), which means that for Marx work in communism produces knowledge and social relations. The quotation shows that contrary to Negri's claim, Marx advances a non-capitalist concept of work in the Grundrisse.

Also in other of Marx's major writings, work is not confined to capitalism. In Capital, Volume $I$, work is defined as "a condition of human existence which is independent of all forms of society; it is an eternal natural necessity which mediates the metabolism between man and nature, and therefore human life itself" (Marx 1867, 133). Work is "purposeful activity aimed at the production of use-values", "it is common to all forms of society in which human beings live" (Marx 1867, 290).

By the notion of species being, Marx $(1844,74)$ in the Economic and Philosophic Manuscripts means that humans are practical beings that by the interaction of their activities and ideas change the world. "[L]ife-activity" - "productive life itself" - is a "means of satisfying a need", "free, conscious activity is man's species character" (Marx 1844, 75). Man "produces even when he is free from physical need and only truly produces in freedom therefrom" (Marx 1844, 75). For Marx, work is a creative human activity conducted in society: "what I create from myself I create for society, conscious of myself as a social being " ${ }^{\text {"15. }}$.

In the Manuscripts, Marx also uses the German term Werktätigkeit for describing human species being, which expresses that humans in their practices create works (Werk=a work, Tätigkeit=practice, Werktätigkeit = practices that create works): "Eben in der Bearbeitung der gegenständlichen Welt bewährt sich der Mensch daher erst wirklich als ein Gattungswesen. Diese Produktion ist sein werktätiges Gattungsleben. Durch sie erscheint die Natur als sein Werk und seine Wirklichkeit. Der Gegenstand der Arbeit ist daher die Vergegenständlichung des Gattungslebens des Menschen: indem er sich nicht nur eine im Bewußtsein intellektuell,

\footnotetext{
${ }^{15}$ http://www.marxists.org/archive/marx/works/1844/epm/3rd.htm
} 
sondern werktätig, wirklich verdoppelt und sich selbst daher in einer von inm geschaffnen Welt anschaut" (Marx 1844, 517).

This passage has been translated into English the following way: "It is just in the workingup of the objective world, therefore, that man first really proves himself to be a species being. This production is his active species life. Through and because of this production, nature appears as his work and his reality. The object of labour is, therefore, the objectification of man's species life: for he duplicates himself not only, as in consciousness, intellectually, but also actively, in reality, and therefore he contemplates himself in a world that he has created" (Marx 1844, 76). The adjective werktätig has here been twice translated with active, which is not a very suitable translation and can easily mislead English-speaking readers: "Active species-being" could literally be better translated with "working species-being". Marx also writes that by this kind of species-being nature appears as man's Werk and Wirklichkeit, which is translated with work and reality, a translation that does not capture the full meaning: Marx has here deliberately chosen the two words Werk and Wirklichkeit because they are connected: Wirklichkeit comes from the German term wirken that could be translated with creative work that transforms and has transformative effects on reality (Wirklchkeit). The term work stems from the German notions of wirken and werken: in their work humans transform reality - das menschliche Werken wirkt in der Wirklichkeit (Human work works on reality).

The idea that work is a practical human activity and in communism becomes a creative, self-determined activity of human life is a constant element of Marx's thoughts from his early to his late works. Not all Autonomist Marxists share the view that work should be conceptualized as necessarily coerced, alienated and a capitalist concept. So for example John Holloway $(1995,171)$ argues with Marx that work is "the creative power of human practice". The "existence of work as value-producing labour [in capitalism] does nothing at all to change the all-constitutive power of work: since work is the only creative force in society (any society), it could not be otherwise" (Holloway 1995, 172). Holloway argues that the central insight of Marx's law of value is that human work is a form of empowerment against capital, the capacity of humans to become independent of capital: "behind all the forms of our powerlessness lies the one thing that makes us all-powerful: work. That is the first, obvious, and generally overlooked, meaning of the labour theory of value. It is a great chest-thumping cry: 'we humans, as workers, are all=powerful" (Holloway 1995, 177).

An associated claim of the first type of argument brought forward against the concept of work is that the word work did not exist before capitalism (e.g. Cleaver 2002, 2003). Harry Cleaver (2000) elaborated an important political reading of Marx's Capital. The importance of it lies not only in the circumstance that it is a political interpretation, but also that it is a Hegelian reading of Marx, which is rather rare today in Marxism in general and Autonomist Marxism in particular, but can, as Cleaver shows, help stressing Marx's focus on capitalism's class relation between labour and capital and associated struggles. Cleaver seems to have revised his view on the questions how to define work and if there is work in a communist society: whereas in his works from 2002 and later he makes statements like "the liberation of work can come only with the liberation from work, that is, from the capitalist reduction of life to work" (Cleaver 2011,61$)^{16}$, in the $2^{\text {nd }}$ edition of Reading Capital Politically published in 2000 that has been widely translated into languages such as German, Indian, Korean, Mexican, Polish and Turkish, he uses the term "'unalienated' work" that he sees as "work as an activity which is not a function of domination", which involves "the elimination of the element of compulsion" (Cleaver 2000, 130).

The arguments that the concept of work did not exist before capitalism and that work means the same as labour are mistaken because they ignore the etymological origins of the term. Brigitte Weingart (1997) describes the origins of the terms work in English and Arbeit and Werk in German: In German, the word Arbeit comes from the Germanic term arba, which meant slave. The English term work comes from the Middle English term weorc. It was a fusion of the Old English terms wyrcan (creating) and wircan (to affect something). So to

\footnotetext{
${ }^{16}$ A similar formulation can be found in Gorz' work, who says it is necessary to free the working class "from work" (Gorz 1982, 2).
} 
work means to create something that brings about some changes in society. Weorc is related to the German terms Werk and werken. Both work in English and Werk in German were derived from the Indo-European term uerg (doing, acting). Werken in German is a term still used today for creating something. Its origins are quite opposed to the origins of the term Arbeit. The result of the process of werken is called Werk. Both werken and Werk have the connotative meaning of being creative. Both terms have an inherent connotation of artistic creation. In Austria, there is a school subject called Werken in all secondary schools ${ }^{17}$. Its nation-wide curriculum does not stress that pupils should be prepared for becoming wage labourers, but in contrast rather that Werken is "a creative process that fosters the autonomy in the development of problem solution strategies", contributes "by the assessment of technology's impacts" to "moral and ethical competences for impacts of human action" and the responsible handling of natural resources ${ }^{18}$. So there are reasons why this school subject is not called Arbeitslehre (labour studies) but Werken. This circumstance captures the differences between Arbeit and Werk, labour and work.

\section{German English}

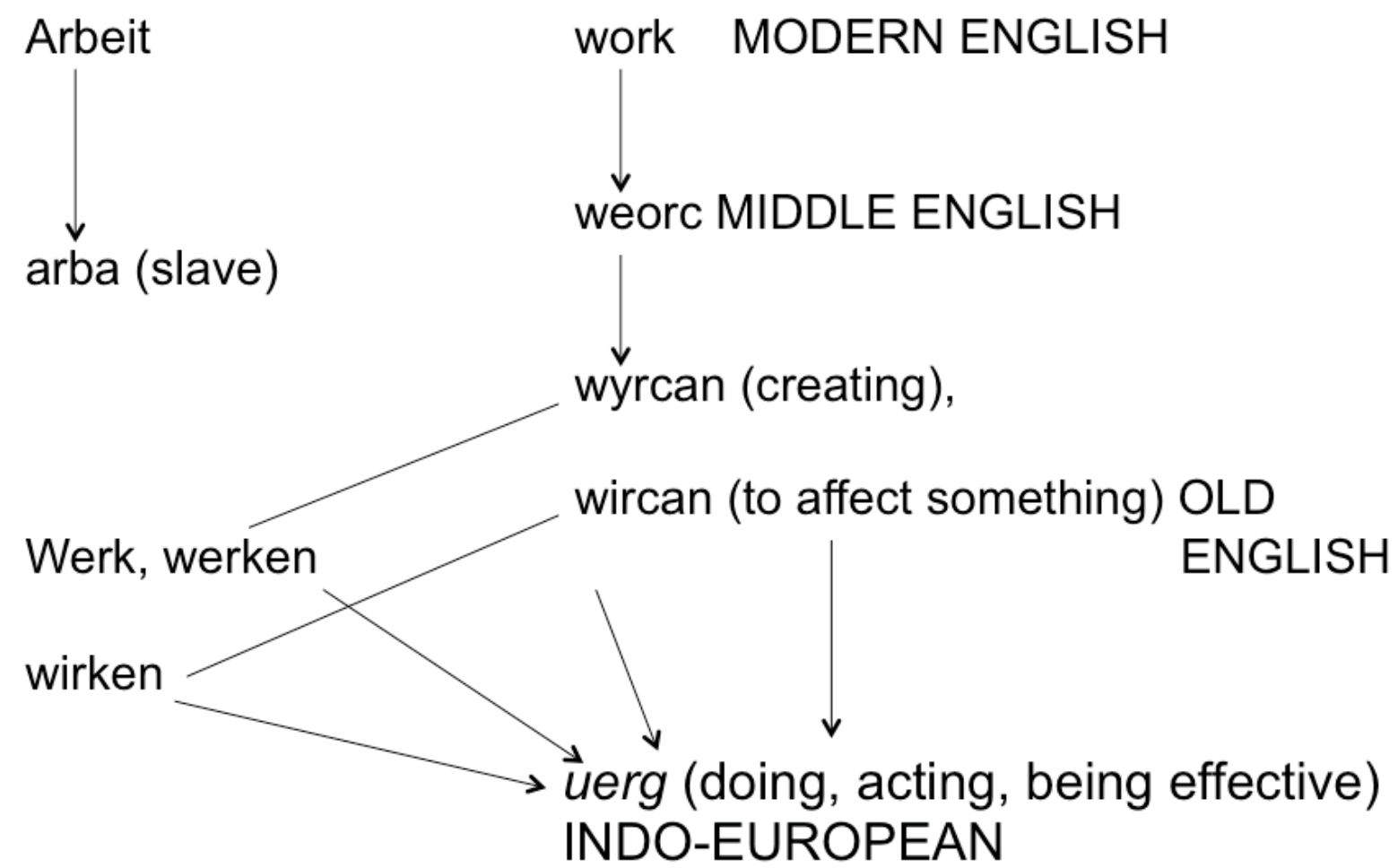

Figure 10: Etymology of the terms work and Arbeit

So Marx does not, as argued by Harry Cleaver, take a genuinely capitalist concept and project it forward and backward in history. He is rather aware that the German term Werktätigkeit is an anthropological feature of all societies and therefore characterizes human being as "werktätiges Gattungsleben" (Marx 1844, 517) = working species being. Marx used a dialectic of the general and the concrete for thinking about capitalism and other types of societies: there are general characteristics that are common to all societies and specific historical features that these dimensions take on under specific historical conditions. By developing a critical theory of capitalism Marx not only uncovered this society's logic, but also

\footnotetext{
${ }^{17}$ See http://de.wikipedia.org/wiki/Werkunterricht

${ }^{18}$ Translation from German. Lehrpläne technisches Werken, AHS-Unterstufe, http://www.bmukk.gv.at/medienpool/792/ahs17.pdf
} 
showed how the logic of capital accumulation estranges human beings from society as such, which requires a concept of society in general that Marx developed in constant interaction with the categories that are specific for capitalism.

\subsection{Is there a Real and an Unreal Marx? Refuting the Myth of Inconsistency}

A second common argument of anti-work philosophy is to point out that something is wrong with Marx's concept of work, e.g. to claim that Marx fetishized productive work and had no sense for idleness (Black 1996) or that the "real Marx" wanted to abolish work along with capitalism (Negri 1991). No matter what the specific claim is, the overall line of argument is that there is something wrong with Marx's concept of work and that only a certain idea, book or interpretation of this concept is the right one and that other original Marxian writings on work have to be refuted.

Kathi Weeks (2011) makes in this respect a prototypical argument by distinguishing between three Marxes:

- The productivist Marx of Capital and the Communist Manifesto who wants to have more work, sees sloth as a sin and influenced Leninism's and Stalinism's work ethics (Weeks 2011, 82-85).

- The humanist Marx of the Economic and Philosophic Manuscripts and the German Ideology who wants to have better, non-alienated work and influenced humanist socialists such as Erich Fromm (Weeks 2011, 85-89).

- The "good" anti-work Marx of the Grundrisse who wants to abolish, refuse, reduce and overcome work, cherishes idleness and who influenced Negri and other Autonomist Marxists (Weeks 2011, 92-103).

Weeks in a move remindful of Althusser's (1969) claims that Marx's works on work are inconsistent and that he changed his positions. We want to refute this myth of inconsistency that only helps conservative opponents of Marx to construct the argument that Marx was wrong.

A consistent theme in Marx's works is the stress on the role of industry and technology for reducing the working day, i.e. the hours of necessary work needed for the survival of humanity. Technology would tend to create misery under capitalism, but can create new forms of well-rounded individuality in a free society. Already in the 1844 Manuscripts, Marx (1844, 110 ) points out that natural science and industry have "prepared human emancipation, however directly and much it had to consummate dehumanization". In the German Ideology's Feuerbach chapter, Marx says that communism "presupposes the universal development of productive forces" (Marx and Engels 1845/46, 57) and that the developed productive forces enable a well-rounded individuality (53). Creative activities and the reduction of necessary working time are here two sides of one coin.

In the Grundrisse, Marx continued to stress this connection by pointing out: "The less time the society requires to produce wheat, cattle etc., the more time it wins for other production, material or mental. Just as in the case of an individual, the multiplicity of its development, its enjoyment and its activity depends on economization of time. Economy of time, to this all economy ultimately reduces itself" (Marx 1857/58b, 172f). In a similar passage, he later in the book wrote: "The saving of labour time [is] equal to an increase of free time, i.e. time for the full development of the individual, which in turn reacts back upon the productive power of labour as itself the greatest productive power" (Marx 1857/58b, 711).

Also in Capital, Volume 1, Marx stresses the connection of technological productivity, the reduction of necessary work time and creative work: "The more the productivity of labour increases, the more the working day can be shortened, and the more the working day is shortened, the more the intensity of labour can increase. From the point of view of society the productivity of labour also grows when economies are made in its use. This implies not only economizing on the means of production, but also avoiding all useless labour. The capitalist mode of production, while it enforces economy in each individual business, also begets, by its anarchic system of competition, the most outrageous squandering of labour-power and 
of the social means of production, not to mention the creation of a vast number of functions at present indispensable, but in themselves superfluous.

The intensity and productivity of labour being given, the part of the social working day necessarily taken up with material production is shorter and, as a consequence, the time at society's disposal for the free intellectual and social activity of the individual is greater, in proportion as work is more and more evenly divided among all the able-bodied members of society, and a particular social stratum is more and more deprived of the ability to shift the burden of labour (which is a necessity imposed by nature) from its own shoulders to those of another social stratum. The absolute minimum limit to the shortening of the working day is, from this point of view, the universality [Allgemeinheit] of labour. In capitalist society, free time is produced for one class by the conversion of the whole lifetime of the masses into labour-time" (Marx 1867, 667).

Given that Marx consistently stresses throughout his works that there is a necessary connection between productivity, technology, the reduction of necessary work time, well-rounded individuality and free creative work, it is infeasible to assume as Weeks and others do that Marx had an inconsistent concept of work. It is an artificial separation to argue that one has to choose between one of three Marxes, the ones demanding "more work, better work, and less work" (Weeks 2011, 104). It is rather a consistent theme in Marx's oeuvre that the technological increase of productivity intensifies (and to a certain degree also extends) work in capitalism (more work and exploitation in less time, more work as longer working hours), but has the potential to lessen necessary work for all (less work) in a post-capitalist society to a minimum so that alternative forms of work (better work) emerge that are non-coerced, go beyond necessity and are an expression of well-rounded individuality and human creativity. Modern technology has a dialectical character in that it contains potentials for the abolition of labour and toil as well as the freeing up of human life so that there is time for creativity as well as a reality of intensified alienation, i.e. non-control of humans over their own lives. A free society sublates (aufheben) work: it eliminates its coerced, exploitative and toilsome aspects, i.e. it eliminates labour, it preserves certain aspects of contemporary work organization, such as the importance of technology for achieving high productivity, and it uplifts society and economy to a new level, on which human individuality is well-rounded and all humans are enabled to have the time and possibilities for expressing creativity.

\subsection{Are People who Argue for an Alternative Concept of Work Stalinist Labour Fetishists? Why We Need to Repeat William Morris and Herbert Marcuse in the Digital Labour Debate.}

A third argument of anti-work philosophy is that Marx was a productivist, i.e. that he stressed the need for being productive in order for humans to exist, which has turned into an ideological socialist work ethic that wants to eternalize toil and hates idleness. Weeks (2011) claims that productivist elements can be found in Marx's Communist Manifesto and Capital. Part of this argument is the criticism of Soviet ideology's use of the claim that everyone has become a worker for legitimatizing forced labour.

Harry Cleaver writes that the idea that in communism everyone is a worker is an "ideology that has justified the brutal socialist imposition of work" (Cleaver 2003, 56). Our argument is that not everyone becomes a worker in communism, but that everyone in every society is always a worker of the commons that are created and reproduced by all. So Soviet ideology got it wrong by arguing that work became liberated and everyone became a worker in the Soviet Union.

The stress on necessary toil in Soviet Marxism is no wonder given that the Soviet system was first a predominantly agricultural and later an industrializing society that assumed that it could catch up with and overhaul Western capitalist countries' productivity. Herbert Marcuse (1958) stresses that the Protestant labour ethic was both an element of the Soviet system and Western capitalism. In the Soviet system, "love for one's work' is per se one of the highest principles of Communist morality, and work per se is declared to be one of the most important factors in the building of moral qualities. [...] Many of the rules of conduct in school 
and home, at work and leisure, in private and in public, resemble so much their traditional Western counterparts at earlier stages that they have the sound of secular sermons documenting the 'spirit of Protestant-capitalist ethics'. They are not too far from Puritan exhortations to good business" (Marcuse 1958, 234, 242). The religious component of this ethic is evident in the philosophy of Christianity, where work has been as a virtue, as expressed in Paulus' ethics of labour: "The one who is unwilling to work shall not eat" (2 Thessalonians 3 ).

Paulus' labour ethic was directly reflected in Soviet ideology, which renders Lenin and Stalin more religious than they are generally considered to be. Lenin $(1917,342)$ wrote: "He who does not work shall not eat" is a "socialist principle". Stalin reflected this idea: "The basis of the relations of production under the socialist system, which so far has been established only in the U.S.S.R., is the social ownership of the means of production. Here there are no longer exploiters and exploited. The goods produced are distributed according to labour performed, on the principle: "He who does not work, neither shall he eat'" (Stalin 1938). This principle was also written into Article 18 of the 1936 Constitution of the USSR: "The Russian Socialist Federative Soviet Republic declares labour to be the duty of all citizens of the Republic, and proclaims the slogan: 'He who does not work, neither shall he eat!"'19

These examples are indications that the Soviet system was based on coercive labour and a religious labour ideology that aimed at increasing productivity as quickly as possible. So it is definitely true that the Soviet system reproduced the repressive organization of work characteristic for labour under capitalism. This does however not imply that the concept of work cannot obtain a meaning that is in line with Marx's vision of a non-repressive organization of human activities that are expressions of well-rounded individuality under the conditions of the minimization of necessary working time.

In Capital, Volume 3, Marx says that capitalism "creates the material means and the nucleus for "a higher form of society, with a greater reduction of the overall time devoted to material labour. [...] The realm of freedom really begins only where labour determined by necessity and external expediency ends; it lies by its very nature beyond the sphere of material production proper. [...] The reduction of the working day is the basic prerequisite" (Marx $1894,958 f)$. Marx's theme of the realm of freedom beyond necessity has been reflected in Herbert Marcuse's works: He says that a free society must be a highly productive knowledge society where "the prevailing 'economics of time' (Bahro) can be overthrown" and there is "free, creative time as the time for life" (Marcuse 1979, 223). Technology "may one day help to shift the center of gravity from the necessities of material production to the arena of free human realization" (Marcuse 1941, 63). Such a new society would be shaped by "the planned utilization of resources for the satisfaction of vital needs with a minimum of toil, the transformation of leisure into free time, the pacification of the struggle of existence" (Marcuse 1964, 252f). Alienation could be overcome: "The technological processes of mechanization and standardization might release individual energy into a yet uncharted realm of freedom beyond necessity [...] the individual would be liberated from the work world's imposing upon him alien needs and alien possibilities. The individual would be free to exert autonomy over a life that would be his own" (Marcuse 1964, 2). Marcuse $(1965,22)$ says that in a free society there will be "the redefinition of work in terms of a free realization of human needs and facilities". Technique would then be art "as construction of the beautiful, not as beautiful objects or places but as the Form of a totality of life - society and nature" (Marcuse 1967a, 119). In a free society, society can become a work of art (Marcuse 1967b, 128).

Marcuse's themes have been anticipated by and reflected in the works of William Morris $(1884 b, 98)$ who questioned that "all work is useful". It is a conservative ideology to assume that "all labour is good in itself" (Morris 1884b, 98). There is work that is a curse and should be refused (Morris 1884b, 98). The current conservative British government uses the labour ethic as ideology against the unemployed. In April 2013, it introduced benefit caps that Work and Pensions Secretary lain Duncan Smith justified by saying that they pose "a strong incen-

\footnotetext{
${ }^{19}$ http://www.departments.bucknell.edu/russian/const/18cons01.html
} 
tive for people to move into work" ${ }^{20}$. It does not matter for the UK government which work one has, how much one earns, the stress is only on the circumstance that one works or should work in order to be exploited by capital. Unnecessary, hard and harmful work has no moral right to exist. It should be abolished as soon as possible.

There is a lot of unnecessary, useless labour (a waste of human energy) and labour that can be automated. Unnecessary labour is work that is not needed for the survival of humankind. It includes for example labour that controls the work force and private property, such as managers, directors, chief executives, protective and security workers, employment agents; labour that secures the state's monopoly of violence, such as lawyers, judges, police inspectors, police officers, prison guards, soldiers; labour that organizes the monetary economy, such as accountants, brokers, securities and finance dealers, insurance representatives, bank personnel, debt collectors, estate agents, cashiers, sales personnel and vendors. A society that abolishes money and the private property of the means of production can abolish or drastically reduce a lot of these occupations because money then no longer mediates the economy, there are no longer any wage earners that need to be controlled and monitored, private property no longer needs to be secured and guarded and property-related conflicts and crimes are likely to be reduced.

Useless work is today accompanied by some useless forms of entertainment that should no longer exist in a free society, especially those that are directly about winning money, such as gambling, betting and the lottery. Also other stupefying activities, such as reading tabloids and horoscopes, are likely to vanish because tabloids are an expression of a highly commercialized press and horoscopes a form of organized irrationality. This does not mean that useful forms of playful entertainment, such as music, films, non-competitive sports etc should no longer exist in a free society, but that money-mediated and ideological culture is likely to cease to exist. Many forms of organized and administered sports reflect the ideologies of nationalism, patriarchy, racism, individual, competition and the fascist idealization of bodily strength that implies an implicit disregard of the weak. The liberal standard argument against these thoughts is: Wait a minute, there are also female soccer teams, anti-nationalist and anti-racist soccer fan clubs, the Paralympic Games, etc. These phenomena are like light beer: they are created for consoling the critics, but those who take joy in ideological sports that they consider as the "real thing" covertly or overtly laugh about and make fun of those who watch female soccer or the Paralympic Games, which even more asserts the ideologies that the liberal phenomena are supposed to dampen. But what if administered competitive sports are inherently racist, fascist, patriarchal and nationalist? We will have to reinvent sports in a new society.

Harmful work is work that harms the survival-capacities of humans. It includes e.g. the killing conducted by soldiers, the operation of nuclear power plants and fossil-fuel power stations, all forms of work that involve health risks (such as coal mining that increases the lung cancer risks, labour conducted at toxic workplaces), the production of cars powered by fossil fuels, jobcentre staff responsible for sanctioning unemployed people, etc.

There is also repetitive, hard and physically exhausting work that can be reduced and minimized by labour-saving technologies. Examples are cleaners, waste workers, machine operators, assemblers, metal workers, builders, miners and quarry workers, agricultural workers, forestry workers, waiters and waitresses, housekeepers, mail carriers, warehouse workers, transport workers, secretaries, data entry operators, call centre agents. Robots and automation can reduce the amount of repetitive, hard and exhausting work in society. It may however not be possible to entire abolish such activities. The question if work in a free society functions can be well envisioned by imagining how the most degrading and disgusting work would be organized.

What happens to shit work in a literal sense in a free society? Cleaning toilets is one of these forms of work. Who cleans the toilets in a free society? One possibility is to automate humans to such an extent that they no longer digest. Besides the question if this is techno-

1. ${ }^{20}$ BBC Online, Iain Duncan Smith criticised over benefit cap figures. http://www.bbc.co.uk/news/ukpolitics-22462265. May 9, 2013. 
logically possible, the moral question is if it is desirable and what would happen if the human turned into a machine or semi-machine. Another possibility is to automate toilet cleaning. There are constant advances in the development of toilet-cleaning robots (TCRs). Selfcleaning toilet seats are an early version of the automation of toilet cleaning. The iRobot Scooba is a floor-washing robot that can also clean the floor around toilets, i.e. those parts of bathrooms that are especially prone to be peed on by men and women who prefer to stand or knee instead to sit and tend to miss the bowl while urinating. In the case of the not uncommon phenomenon of really dirty public toilets, this tendency reinforces itself because understandably nobody wants to sit down on or touch a dirty toilet lid and therefore many people stand or knee in public toilets, which due to aiming inaccuracies just intensifies the problem of disgusting toilets that one set out to avoid. In 2007 a consortium of robotics companies developed a TCR in Japan ${ }^{21}$.

Imagine a world, where TCRs clean all public and private toilets. One may say that this is a stupid thought experiment, that public toilets are sometimes so dirty because people express the way they feel about their alienation in society in the way they deal with their own shit and pee in public toilets, that therefore people will keep public toilets much cleaner in a free society, etc. All of this is however highly speculative and the problem of a public toilet is that given that so many people frequent it, the likelihood that one person unintentionally or deliberately floats it or pollutes it with misdirected shit and/or pee is quite high. We therefore can never guarantee that public toilets are kept clean.

So let us imagine a world of toilets managed by TCRs, in which the occupation of the human toilet cleaner is abolished. Robots are complex systems that function based on algorithms and cannot work based on reason. Therefore they will always be prone to failure, not be able to clean some toilets, have technical problems, mistake toilets with other objects, etc. So somebody has to develop, maintain and repair TCRs. The problem of development could be solved once TCRs are at a high technological level and can be automatically manufactured by hardware printers. But of course somebody needs to develop and maintain hardware printers up to the point where universal hardware printers can print themselves, which just requires maintenance work. If TCRs fail, then somebody has to clean the toilets. Imagine a public toilet at a heavily frequented public train station, where the TCRs are out of operation for two weeks due to a technical failure. Either nobody cleans the toilets, which may result in overflowing and really disgusting toilets that can no longer be used, requiring people to urinate and defecate in public, which spreads diseases, attracts rats and over some time results in diseases such as pestilence. Or everyone thoroughly cleans the toilet after s/he has used it. Or toilet-cleaning work is distributed among all when TCRs fail. Or voluntary workers take over the TCRs' role for a limited time. The example wants to show that human work can be largely, but never fully automated because high-tech machines are complex and failure-prone. The reason for this is that machines other than humans do not have reason, morals and anticipatory thinking.

Creative work is work, in which humans reflect a lot and envision by anticipatory reflection how parts of the world could look like, be organized and changed. Such work tends to be gratifying. It includes the works of e.g. engineers, architects, librarians, authors, artists, composers, journalists, sculptors, painters, musicians, signers, choreographers, dancers, actors, film directors, decorators, designers and gardeners. Creative work can make the world a nicer and more beautiful place. Reducing the necessary working time enlarges the potential time for creative work. A free society can also abolish the division of labour so that everyone is enabled to become a creative worker as s/he pleases. William Morris $(1884 \mathrm{~b}, 87)$ stresses the importance that work is pleasurable and that workers enjoy "hope of rest, hope of product, hope of pleasure in the work itself; and hope of these also in some abundance and of good quality". The precondition for these hopes to become reality is that "class robbery is abolished" (Morris 1884b, 99) and that a "Society of Equality" (Morris 1893, 265) is established. Morris imagined a post-capitalist condition, in which labour-saving technology reduces hard labour and humans are enabled to engage in creative and artistic work, by which they

\footnotetext{
${ }^{21} \mathrm{http}: / /$ inventorspot.com/articles/cute cleaning robot cleans toile 8541
} 
create "ornaments of life" (Morris 1884b, 116) as popular art (Morris 1884b, 113) and "a beautiful world to live in" (Morris 1885, 25).

Creativity could then become a "pleasure which is unknown at present to the workers, and which even for the classes of ease and leisure only exists in a miserably corrupted and degraded form. I mean the practice of the fine arts: people living under the conditions of life above-mentioned, having manual skill, technical and general education, and leisure to use these advantages, are quite sure to develop a love of art, that is to say, a sense of beauty and an interest in life, which, in the long run must stimulate them to the desire for artistic creation, the satisfaction of which is of all pleasures the greatest" (Morris 1884c, 2). Some or many "would find themselves impelled towards the creation of beauty [...] our factory which is externally beautiful, will not be inside like a clean jail or workhouse; the architecture will come inside in the form of such ornament as may be suitable to the special circumstances" (Morris 1884c, 2). "One's imagination is inclined fairly to run riot over the picture of beauty and pleasure offered by the thought of skilful co-operative gardening for beauty's sake, which beauty would by no means exclude the raising of useful produce for the sake of livelihood. [...] So in brief, our buildings will be beautiful with their own beauty of simplicity as workshops, not bedizened with tomfoolery as some are now, which do not any the more for that, hide their repulsiveness" (Morris 1884a).

Some socialists have characterized Morris as romantic idealist, moralist, utopian, anarchist and sentimentalist. Karl Kautsky was the first who in 1884 characterized Morris as "sentimental socialist" (Hampton 2008), a judgement that was repeated by Engels (1886b) in a letter to Laura Lafargue, Karl Marx's daughter. Engels also wrote that Morris is "a sentimental dreamer pure and simple, the personification of good will with so good an opinion of itself that it turns into ill will if ever there's a question of learning anything, has been taken in by the catchword 'Revolution' and fallen victim to the anarchists" (Engels 1886a). Engels was convinced that socialism has to be scientific instead of utopian, which means that revolution and communism will with necessity like a natural law develop out of the contradictions of capitalism. We today know that history has falsified this assumption. Just like Morris' contemporaries vituperated him as idealist utopian, some of Herbert Marcuse's contemporaries conducted the same ideological operation by saying that Marcuse was a technological utopian (e.g. Habermas 1969). Edward P. Thompson argued in his 1976 postscript to his book William Morris: Romantic to Revolutionary that "Engels's disdain for Morris exemplifies the narrowing orthodoxy of those years, a narrowing noted not only in his own writings but in the Marxist tradition more generally" (Thompson 2011, 786). This tendency would have been characterized by "determinism and positivism" (Thompson 2011, 786). Morris in contrast stands for Thompson (2011) for an agency-based Marxism that doubts determinism and evolutionism (795) and vindicates concrete utopias as political force (792f). For Thompson (2011), Morris is "our greatest diagnostician of alienation" (801) and stands for a Marxism that acknowledges both the importance and interaction of the economy on the one hand and morality and culture on the other hand (804), helps "people to find out their wants, to encourage them to want more, to challenge them to want differently, and to envisage a society of the future in which people, freed at last of necessity, might choose between different wants" (806) and asks the question "How Shall We Live Then?" (809). Peter Linebaugh (20111, viii) adds to this assessment that one important aspect of Morris is that he was a green communist who demanded to unwaste nature and work. Thompson $(1994,75)$ says that Morris and Marx complement each other and allow us to see that economic "relationships are at the same time moral relationships, relations of production are at the same time relations between people, of oppression or of co-operation: and there is a moral logic as well as an economic logic, which derives from these relationships".

William Morris and Herbert Marcuse not only share the political conviction that a free society beyond the realm of necessity is possible, but also that labour-saving technology can in such a framework abolish necessary labour, toil and that this framework can enable creative work and the becoming-art of the economy. It is no wonder that functionalists have dismissed their humanist Marxism, which just shows that their perspectives are much needed. The alternative to anti-work philosophy is not Stalinist labour fetishism, but the abolition of unnec- 
essary and harmful work, the reduction of hard work and the enablement of creative work, the becoming-art of work and the becoming-art of society.

\subsection{The Conceptual and Political Limits of Antiwork}

The introduced antiwork approaches do not much consider the question if there are qualities that characterize all societies and all economies and how these qualities can best be termed. They construct critiques of capitalism without a theory of society. Some of them engage with the question of how a concept that characterizes alternatives to work in a free society should be termed: suggestions are antiwork, postwork, life, self-determined activity, self-valorization and self-constitution. Antiwork and postwork do not name a specific form of activity, but rather define themselves by what they are opposed to and what they refuse (antiwork) or by a future point of time (postwork). They do not have a vision of how work can be organized in a free society. Life, self-determined activity and self-constitution are concepts that are too general for characterizing work in a free society. Also a virus is a form of life, but we do not say that it works on the body when infecting or killing a human being. Self-determined activities not only exist in a free society, but also to a certain extent today. Not all forms of selfdetermined and self-constituted activities are equivalents of work. Sleeping is an activity that is needed for constantly re-constituting the mind and the body, it is self-constitution and selfreproduction, but different from work. The decision to go out and take a walk or to stay indoors and sleep is a relatively self-determined activity, but no work. Work creates novelty in the world that satisfies some human needs. Now you can say that dreaming satisfies the human need to rest and produces a dream and that tooth brushing and showering satisfy the human needs of cleanliness, so why are these activities, but not human work? It is certainly work of the human brain as an organ, but not work of human beings as interaction of body and mind and social interaction because it does not have broader social effects in human groups. Humans not only produce and create for themselves, they do so for others and in a true society do so to help and benefit not only themselves, but society at large. Human work is a social relationship, It is oriented towards others not just towards oneself. Work does in reality not occur in isolation. The life of Robinson on an island would due to social isolation and lack of biological reproduction soon come to an end. Marx (1857/58b, 83) criticized Adam Smith and David Ricardo for taking the "individual and isolated hunter and fisherman" as "point of departure" of the analysis of material production. The point of departure for the analysis of the economy should in contrast be "[i]ndividuals producing in society" (Marx 1857/58b, 83).

It is also doubtful that self-valorization is a better term than work for characterizing the creation of goods and relations that satisfy human needs in a free society. Marx (1867) titled chapter 7 of Capital, Volume 1, "The Labour Process and the Valorization Process". The work process creates use-values (Marx 1867, 302) and this process is in capitalism connected to the "process of valorization", which is "the capitalist form of the production of commodities" (Marx 1867, 304) and in which surplus-value is generated that "results only from a quantitative excess of labour" (Marx 1867, 305). Marx describes that capital is a dynamic process and that in this process the exploitation of labour fosters the accumulation of capital. Capitalism is like a value-generating machine built on and driven by the exploitation of labour: "By turning his money into commodities which serve as the building materials for a new product, and as factors in the labour process, by incorporating living labour into their lifeless objectivity, the capitalist simultaneously transforms value, i.e. past labour in its objectified and lifeless form, into capital, value which can perform its own valorization process, an animated monster which begins to 'work', 'as if its body were by love possessed"' (Marx 1867, 302). Capital is self-valorizing value. Negri opposes the concept of capital's self-valorization to worker selfvalorization (Negri 1991, 148). Self-valorization means "independence of the worker-subject" (Negri 1991, 135), "non-work" (149). Negri argues that it starts with the refusal of work in capitalism and comes to full effect in communism (Negri 1991, 148). Michael Ryan in the introduction to the English translation of Negri's (1991) Marx beyond Marx says Negri understands self-valorization as "working for oneself as a class, asserting one's own needs as pri- 
mary to capital's need for value" (Negri 1991, xxx). Harry Cleaver $(1992,129)$ defines it as "a process of valorisation which is autonomous from capitalist valorisation - a self-defining, selfdetermining process which goes beyond the mere resistance to capitalist valorisation to a positive project of self-constitution" that constitutes a "working class for-itself".

The basic idea that Negri expresses is the way that Marx imagined work in a free society - a creative process controlled by the immediate producers, who no longer work for others, but control their work, working time and produce for society as a whole and therefore for themselves. Given that Marx saw the concept of valorization deeply entrenched with capital accumulation, it is not self-evident that this concept can be rescued by prefixing "self" and used for signifying a process of liberation and a status of emancipation. By abolishing capitalism and establishing a free society, the revolutionary class in a movement of universality not only abolishes itself and capital and thereby all classes, it also abolishes valorization. The term self-valorization can easily be understood or mistaken as meaning the continuation of capital accumulation with workers as shareholders or collective capitalists and the maintenance of the wage, money and commodity system. So although the content of Negri's selfvalorization concept expresses important transformations of work in a free society, the very term is confusing and easily creates the impression of signifying not the abolishment, but the a mere transformation of capitalism. Substituting the term non-alienated work by selfvalorization is not an advantage, but rather complicates the terminology of Marxist theory.

Terms such as antiwork, zerowork and postwork are unlikely to convince or mobilize the overall majority of people to struggle against capital and their own labour. Such terms may have an appeal for a limited group of Anarchists and Autonomists, but the majority of people seem way too much acquainted with the idea that work is not just a burden, but has positive qualities. Abolishing and refusing labour and capitalism may be easier to advance not by slogans such as the "refusal of work", but the "refusal of toil", the "reduction of unnecessary, burdensome and harmful work" and the enablement of the "creativity of all".

The World Values Survey (WVS) is an opinion poll conducted in more than 50 countries. It focuses on human attitudes towards a variety of normative questions that concern contemporary societies. Like many surveys, it surely has its own biases, but as long as a worldwide critical worker's inquiry is not available, it may give us a glimpse of how the working population thinks about its work. The WVS provides indications that only a minority of people in the world seem to agree with an anti-work perspective that celebrates idleness. In the World Values Survey $2005-2008,63.4 \%$ of the respondents said that work is very important in life, $27.8 \%$ important, $6.1 \%$ not very important and $2.6 \%$ not at all $(\mathrm{N}=3022) .57 .0 \%$ say it is a bad thing if in the future less importance is placed on work $(\mathrm{N}=75345)$. These values are certainly based on an authoritarian work ethic. This work ethic is however not limited to wage workers, but extends to retired people, house workers, students and the unemployed: $75.3 \%$ of the respondents strongly agree or agree that "Work is a duty towards society" $(\mathrm{N}=63161)$. The share is $72.1 \%$ for full time employees $(\mathrm{N}=21486), 71.1 \%$ for part-time employees $(\mathrm{N}=4244)$, $80.7 \%$ for the self-employed $(\mathrm{N}=8396), 79.6 \%$ for the retired $(\mathrm{N}=8028), 78.9 \%$ for house workers ( $\mathrm{N}=8007), 73.5 \%$ for students $(\mathrm{N}=5035), 74.0 \%$ for the unemployed $(\mathrm{N}=6362)$. $72.2 \%$ of the unemployed respondents say that work is very important in life and $21.8 \%$ that it is important $(\mathrm{N}=7458) .56 .3 \%$ of the unemployed say that it is a bad thing if work becomes less important in the future $(\mathrm{N}=7494)$.

These choices are certainly influenced by the need to survive and the circumstance that most people in capitalism need to earn wages in order to survive. This is reflected in the circumstance that $35.7 \%$ of the respondents say that a good income is the most important aspect of a job, $34.4 \%$ say a safe job with no risk, $10.3 \%$ working with people you like and $19.7 \%$ doing an important job $(\mathrm{N}=74168)$. It is interesting to see that for agricultural workers $(39.6 \%, \mathrm{~N}=3443)$ the most important characteristic is safety, for unskilled manual workers $(40.1 \%, \mathrm{~N}=5074)$ and semi-skilled manual workers $(40.4 \%, \mathrm{~N}=4296)$ a good income, whereas for professional workers who all tend to be knowledge workers the most important characteristic of work is doing an important job $(31.3 \%, N=5910)$. This means that the focus on working for survival seems to be strong in the morals of those whose work involves physical toil or repetitiveness, whereas the focus shifts to a stress of an important content of work in 
the case of skilled knowledge work. Office workers such as secretaries have an intermediary position: they more than manual, but less than professional knowledge workers stress safety and income $(35.4 \%, 31.2 \%, \mathrm{~N}=5991)$ and importance of the work $(21.3 \%, \mathrm{~N}=5991)$.

Given that the work and labour ethic is so widespread, calling for destroying and refusing work may not be a viable strategy for many and calling for antiwork politics is likely to always remain a form of minority politics. Even those who are unemployed, conduct burdensome physical labour or are precarious workers cherish something about work. In a different societal framework, the work and labour ethic is likely to change, but the political question is how one comes from here to there and what slogans work best in political mobilizations. Struggles for self-determined, self-controlled creative work that can freely be exercised by all in a highly productive society that abolishes toil, compulsion, necessity, wages, money, commodities and capital may be easier to achieve and mobilize than struggles that mobilize under the slogans of antiwork, zerowork and the refusal of work that communicate negativity without a positive vision, a negation without a determinate negation, idleness without possibilities for social interaction and self-fulfilling creativity.

In the EU27 countries, the unemployment rate of university-educated 20-24 year olds was $18.5 \%$ in the $4^{\text {th }}$ quarter of $2012,62.1 \%$ in Macedonia, $48.7 \%$ in Greece, $42.7 \%$ in Spain, 42.2\% in Croatia, 38.3\% in Portugal, 35.7\% in Slovakia, 33.0\% in Cyprus, $28.9 \%$ in Turkey, $28.7 \%$ in Romania, $25.9 \%$ in Italy, $22.9 \%$ in Poland, $22.5 \%$ in Lithuania, $20.1 \%$ in Slovenia, $19.4 \%$ in Luxembourg, $18.9 \%$ in Hungary, $17.9 \%$ in Ireland, $17.1 \%$ in France, $17.0 \%$ in Belgium, $13.5 \%$ in the Czech Republic and $12.4 \%$ in the UK (data source: Eurostat). There is a generation of dissatisfied young people, many of whom are no longer willing to accept the system. They are highly educated, skilled and creative and often do not have opportunities to practice the work they are interested in it because they cannot find enough payment for it. Yet they are ready to fight for a different world and many of them already do so in movements such as Occupy, 15-M or the Indignant Citizens Movement. They do not struggle against practicing the creative work capacities they have acquired, they rather struggle against bad working conditions and dull useless labour that allows them no expression of their creativity and is a waste of human energy. Empirical studies show that creative workers often love the content and possibilities for interaction, self-expression and creativity of their work and hate the precarious conditions under which they are often compelled to perform this work such as low income, long working hours followed by periods without work, insecurity, the individualization of risk and the difficulty of combining labour and family (Gill 2002, 2006, Hesmondhalgh and Baker 2011). Abolishing their work is not an option for these young people. They want to be creative workers, but what hinders them is capitalism. A free society must be a highly productive society and as Marx knew the technical development of the productive forces increases the role of knowledge work in society. If one thinks of call-centre agents trying to sell commodities over the phone, then it becomes clear that not all knowledge work is self-fulfilling and an expression of creativity. A feasible political strategy is to call for the abolishment of unnecessary labour such as the one conducted by call centre sales agents, the abolishment of precarious working conditions and the enablement of creative work for all in a society that minimizes necessary work time.

The slogan of the refusal of work in general does not speak to those, who consider themselves to be creative workers, love the content of their work, but hate the precarious conditions under which this work is organized as labour.

There is work that produces commons that cannot be automated if we want to preserve a humane character of society: education, health care, care of the weak and the ill. A free society will have to involve activities of teachers, doctors, nursing professionals, care workers and institutions such as schools and hospitals. The authoritarian character of these institutions that today often makes them prison-like will have to be transformed, but the work of supporting learning and helping the weak and ill will still be needed. They will have a transformed character, but education and care are necessary for human survival. Silvia Federici (2012, 145f) argues in this context: "One crucial reason for creating collective forms of living is that the reproduction of human beings is the most labour-intensive work on earth, and to a large extent it is work that is irreducible to mechanization. We cannot mechanize childcare or 
the care of the ill, or the psychological work necessary to reintegrate our physical and emotional balance. Despite the efforts that futuristic industrialists are making, we cannot robotize 'care' except at terrible cost for the people involved. No one will accept 'nursebots' as care givers, especially for children and the ill" (Federici 2012, 145f).

\subsection{The Future of Work? The Future of Digital Media?}

The contemporary DIY culture involves activities such as guerrilla gardening, urban gardening, balcony gardening, guerrilla knitting, contributing to Wikipedia, developing free software, fanzines, bicycle cooperatives, edupunk, running amateur radio stations on the Internet, blogging, collecting and sharing music online, etc. Digital media has advanced new possibilities for DIY culture (Gauntlett 2011) and "digital craft work" (Gauntlett 2011, 88). Such phenomena are on the one hand certainly an escape from the dissatisfaction with life in capitalism. On the other hand they are the genuine expression of desires for an alternative mode of production that is not based on commodity logic. They show that humans are creative beings and that they strive to overcome alienated work by self-organized creativity. A free society enables everyone to practice creativity.

In a free society, a lot of work becomes a true form of play. Bob Black opposes these two terms as mutually exclusive: "Play is just the opposite [of work]. Play is always voluntary. What might otherwise be play is work if it's forced" (Black 1996). What we really want to see is "work turned into play" (Black 1996). But play is not simply the opposite of work, neither in capitalism nor in participatory communism:

Marx took this idea of attractive work from the utopian socialist Charles Fourier: "It is thus that harmony wishes to distribute the pleasures and the industrial functions, which are the same thing, in harmony, for all labours become there attractive, and are transformed into pleasures" (Fourier 1851, 144).

However Marx had some reservations about the assumption that work can completely turn into pleasure or play. He argued that Fourier's achievement was to recognise that labour should be sublated and not only fairly distributed, but he argues: "Labour cannot become play, as Fourier would like" (Marx 1857/58b, 712). There is a goal of ultimate harmony in Fourier, where the contradiction between subject (man) and object (nature) can be resolved by eliminating the object; not by sublating it in a subject-object (Beecher 1990, 295). Work, as the process wherein subjects and objects are meeting, remains crucial for Marx in any society and under any circumstances: "Really free working, e.g. composing, is at the same time precisely the most damned seriousness, the most intense exertion" (Marx 1857/58b, 611).

The idea of the substitution of work, for instance by play, presupposes a false notion of work as opposed to non-work and free time, which stems from the experience of alienation. Work is, according to Marx, the process through which humans create use-values out of nature. It is also a relation to other humans so that humans are able to shape their relations by themselves. Within play there is the tendency that this basal reference is lost: the freefloating subject may design the rules of the game purely out of her/his will; there is no dialectical relation to an object - be it nature or another subject. We can conclude that work is a necessary aspect of communism. Work is not substituted by play, as Fourier assumed, but rather play becomes work and work becomes a social form of play. One can therefore talk about play work or pleasurable work as the specific communist form of work.

Herbert Marcuse (1955) argues in this context that the performance principle means that Thanatos governs humans and society and that alienation unleashes aggressive drives within humans (repressive de-sublimation) that result in an overall violent and aggressive society. Due to the high productivity reached in late-modern society, a historical alternative would be possible: the elimination of the repressive reality principle, the reduction of necessary working time to a minimum and the maximization of free time, an eroticization of society and the body, the shaping of society and humans by Eros, the emergence of libidinous social relations. Such a development would be a historical possibility - but one incompatible with capitalism and patriarchy. In a communist society, work (and society as a whole) could become 
libidinous and pleasurable, not labour would rule the pleasure principle, but the pleasure principle shape work, the economy and all of society.

Herbert Marcuse $(1965,17)$ argues that consumer capitalism has destroyed the differentiation between labour and leisure/play because "the assimilation of work and relaxation, of frustration and fun, of art and the household, of psychology and corporate management" has made culture affirmative. Today, "the administrative absorption of culture", including play and leisure, into leisure has become a management ideology: The offices of Google and other high-tech companies look like playgrounds. Employees are encouraged to relax, play, party and socialize at the workplace. Management ideology wants to purge all elements of alienation and exploitation in the physical surroundings of labour and the workers' minds. At the same time it hopes that the play labour ideology results in employees working longer hours without more pay. The example shows that Black's assumption that play is communist and work capitalist has been historically falsified by management ideology. In a communist society, the unity of play and labour is not determined by exploitation, but the abolishment of the realm of necessity enables the becoming-art, becoming-true-play and becoming-creativity of work.

What would William Morris and Herbert Marcuse think about YouTube or other usergenerated content platforms? David Gauntlett $(2011,43 f)$ argues in this context: "Morris may have had some concerns about the ways in which today's everyday-creative makers offer their work to be profited from, via advertising, by the owners of the big content-hosting websites such as YouTube [...]. But if we leave that dimension to one side for now, the level of free and spontaneous creative sharing would certainly have given him a warm glow".

Both Morris and Marcuse despised capitalism and the transformation of everyday life by commodity logic. They would have been radical critics of targeted advertising on YouTube, Facebook, Google and similar platforms that advance the commodification of human expression and activities. They also would have been highly critical of the circumstance that mainly popular music organized by large corporations is viewed on YouTube, whereas with some exceptions everyday creative expressions of users are much less viewed. But at the same time Morris and Marcuse would have liked the idea that YouTube and similar platforms socialize human work and have a potential for fostering the becoming-art of work. Morris (1893, 274 ) pointed out that communism is based on the "communication of the means of industry" and the "communication of its product" (274). For this potential to take full effect, it is necessary that means of communication as means of production such as YouTube become communalized so that the Internet turns from a corporate Internet into a commons-based Internet nourished by the creative work of users. Along with this transformed Internet the underlying production processes should be communalized so that the mines, hardware production assemblage factories, software engineering companies etc that are necessary for digital media to exist become worker-owned, -controlled and -operated cooperatives that are based on non-profit production, eliminate private property and the logic of money and commodities. This would be "the realization at last of the meaning of the word COMMONWEALTH" (Morris $1894,277)$ in society and the realm of digital media and digital work.

\section{Conclusion}

In this paper, we have dealt with two questions: What is digital work? What is digital labour? For providing possible answers, theoretical notions of work and labour are needed. We have explored the use of Marx's theory in this context. Marx distinguishes between an anthropological and a historical quality of collective activities that satisfy human needs: work and labour. This distinction is reflected in capitalism in the dual character of the commodity that is both use-value and (exchange) value at the same time. We have set out a Hegelian-Marxist framework for understanding the work process as dialectical interconnection of human subjects (labour power) that use instruments on objects so that products emerge that satisfy human needs. Alienation in capitalist societies is alienation of workers from all poles of this dialectic and from the whole process itself that constitutes class relations and exploitation. 
An answer to the question that we posed earlier and that sometimes divides representatives of the approaches of a) the Political Economy and b) Cultural Studies of social media, namely if the usage of commercial social media results is exploitation of digital labour or a creative and participatory culture, can be given by approaching this issue with the help of Marx's characterisation of work in capitalism as process of concrete labour that creates usevalues and abstract labour that creates the value of commodities. Users of social media are creative, social, and active prosumers who engage in a culture of sharing, doing, connecting and making and in these work activities create social use-values (content, social relations, co-operation). On corporate social media that use targeted advertising, this creativity is a form of labour that is the source of the value of a data commodity that is sold to advertisers and results in profits.

Facebook achieved revenues of US $\$ 3.7$ billion in 2011 (Facebook Registration Statement Form S-1). Mark Zuckerberg was in 2012 the $35^{\text {th }}$ richest person in the world, controlling a wealth of US $\$ 17.5$ billion (Forbes 2012 List of the World's Billionaires ${ }^{22}$ ). The forecast for Facebook's 2012 earnings are US $\$ 4.991$ billion $^{23}$. At the same time, the Facebook stock lost value during 2012 after the initial public offering in May, where the price per share was set at US\$38 (see figure 11). This means that there is a difference between share value and capital accumulation. Facebook tries to attract investors and to thereby increase its capital base and operations. The question is if profits and share values will continuously be stable or if the gap between them will persist.

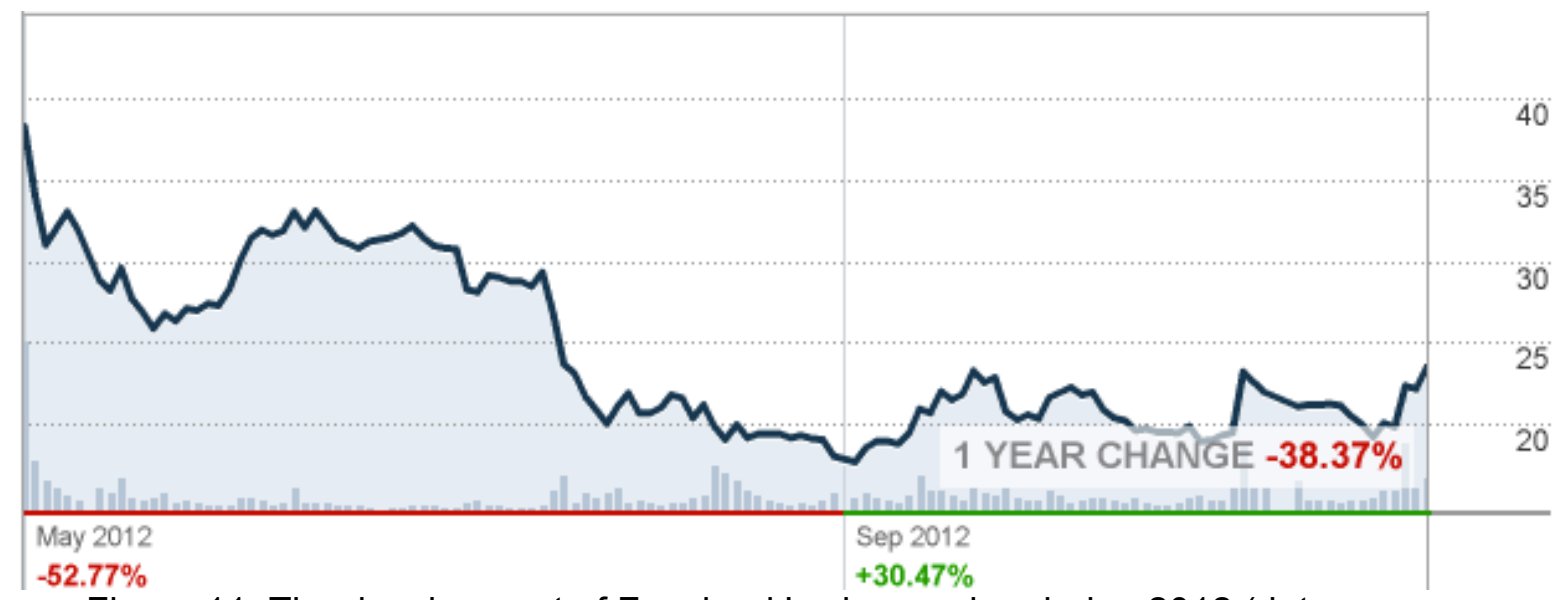

Figure 11: The development of Facebook's share value during 2012 (datas source:

http://money.cnn.com, accessed on Nov 18, 2012)

The argument put forward by this paper is that the wealth of Facebook's owners and the profits of the company are grounded in the exploitation of users' labour that is unpaid and part of a collective global ICT worker. Digital labour is alienated from itself, the instruments and objects of labour and the products of labour. It is exploited, although exploitation does not tend to feel like exploitation because digital labour is play labour that hides the reality of exploitation behind the fun of connecting with and meeting other users. That Facebook has gone public poses the question if it will attract large capital investments and if the expectations these investments raise for profit growth can be matched by actual capital accumulation. Its public listing as stock market company has made Facebook definitely more prone to crisis and therefore more inclined to extend and intensify the exploitation of users. The capitalist Internet has faced a financial bubble before. Capitalism exploded into a big crisis after the bursting of the housing bubble in 2008 . The social media economy's financialization may result in the next big bubble. The only alternative to exit the Internet crisis and exploitation

22

http://www.forbes.com/billionaires/\#p 1 s a0 Technology $\% 20 \% 20 \% 20 \% 20 \% 20 \% 20 \% 20 \% 20 \% 20 \% 20 \% 20 \% 20$ \%20\%20\%20\%20\%20\%20\%20\%20_All\%20countries_All\%20states (accessed on Nov 18, 2012)

${ }^{23} \mathrm{http}: / /$ www.4-traders.com/FACEBOOK-INC-10547141/calendar/ (accessed on Nov 18, 2012) 
economy is to exit from digital labour, to overcome alienation, to substitute the logic of capital by the logic of the commons and to transform digital labour into playful digital work.

\section{References}

Althusser, Louis. 1969. For Marx. London: Verso.

Andrejevic, Mark. 2009. iSpy. Surveillance and Power in the Interactive Era. Lawrence, KS: University Press of Kansas.

Andrejevic, Mark. 2011. Social Network Exploitation. In A Networked Self, ed. Zizi Papacharissi, 82101. New York: Routledge.

Andrejevic, Mark. 2012. Exploitation in the Data Mine. In Internet and Surveillance, edited by Christian Fuchs, Kees Boersma, Anders Albrechtslund and Marisol Sandoval, 71-88. New York: Routledge.

Arvidsson, Adam and Elanor Colleoni 2012. Value in Informational Capitalism on the Internet. The Information Society 28 (3): 135-150.

Beecher, Jonathan F. 1990. Charles Fourier: The Visionary and his World. Berkeley: University of California Press.

Black, Bob. 1996. The Abolition of Work (1996 revised version). http://www.inspiracy.com/black/abolition/abolitionofwork.html

Boltanski, Luc and Ėve Chiapello. 2007. The New Spirit of Capitalism. London: Verso.

Boutang, Yann Moulier. 2012. Cognitive Capitalism. Cambridge: Polity.

Böhm, Steffen, Chris Land, and Armin Beverungen. 2012. The Value of Marx: Free Labour, Rent and 'Primitive' Accumulation in Facebook. http://essex.academia.edu/SteffenBoehm/Papers/1635823/The_Value_of_Marx_Free_Labour_Ren t_and_Primitive_Accumulation_in_Facebook.

Burston, Jonathan, Nick Dyer-Witheford and Alison Hearn, eds. 2010. Digital Labour: Workers, Authors, Citizens. Ephemera: Theory \& Politics in Organization 10 (3).

Caffentzis, George. 2013. In Letters of Blood and Fire. Oakland, CA: PM Press.

Cleaver, Harry. 1992. The Inversion of Class Perspective in Marxian Theory: From Valorisation to Self-Valorisation. In Open Marxism. Volume II: Theory and Practice, edited by Werner Bonefeld, Richard Gunn and Kosmas Psychopedis, 106-144. London: Pluto Press.

Cleaver, Harry. 2000. Reading Capital Politically. Leeds: Anti/Theses.

Cleaver, Harry. 2002. Work is Still the Central Issue! New Words for New Worlds. In The Labour Debate. An Investigation into the Theory and Reality of Capitalist Work, edited by Ana Dienrstein and Michael Leary, 135-148. Hampshire: Ashgate.

Cleaver, Harry. 2003. Marxian Categories, the Crisis of Capital and the Constitution of Subjectivity Today. In Revolutionary Writing. Common Sense Essays in Post-Political Politics, edited by Werner Bonefeld, 39-72. New York: Autonomedia.

Cleaver, Harry. 2011. Work Refusal and Self-Organisation. In Life without Money. Building Fair and Sustainable Economies, edited by Anitra Nelson and Frans Timmerman, 48-68. London: Pluto Press.

Cvijanović, Vladimir, Andrea Fumagallo, and Carlo Vercellone, ed. 2010. Cognitive Capitalism and Its Reflections in South-Eastern Europe. Frankfurt am Main: Peter Lang.

Deleuze, Gilles. 1995. Postscript on the Societies of Control. In Negotiations, 177-182. New York, NY: Columbia University Press.

Eatwell, John, Murray Milgate and Peter Newman. 1987. The New Palgrave. A Dictionary of Economics. Volume 3: $K$ to $P$. London: Macmillan Press.

Engels, Friedrich. 1847. The Principles of Communism. http://www.marxists.org/archive/marx/works/1847/11/prin-com.htm

Engels, Friedrich. 1880. Socialism: Utopian and Scientific. In Selected works in One Volume, Karl Marx and Friedrich Engels, 378-410. London: Lawrence \& Wishart.

Engels, Friedrich. 1886a. Engels to August Bebel in Plauen near Dresden. August 18, 1886. http://www.marxists.org/archive/marx/works/1886/letters/86 08 18.htm

Engels, Friedrich. 1886b. Engels to Laura Lafargue in Paris. September 13, 1886. http://www.marxists.org/archive/marx/works/1886/letters/86 09 13.htm

Engels, Friedrich. 1895/96. The Part Played by Labour in the Transition from Ape to Man. http://www.marxists.org/archive/marx/works/1876/part-played-labour/index.htm

Federici, Silvia. 2012. Revolution at Point Zero. Housework, Reproduction, and Feminist Struggle. Oakland, CA: PM Press. 
Fine, Ben, Heesang Jeon, and Gong H. Gimm. 2010. Value Is as Value Does: Twixt Knowledge and the World Economy. Capital \& Class 34 (1): 69-83.

Fourier, Charles. 1851. The Passions of the Human Soul and their Influence on Society and Civilization: Volume Two. London: Hippolyte Bailliere.

Freud, Sigmund. 1961. Beyond the Pleasure Principle. New York: Norton.

Fuchs, Christian. 2010. Labour in Informational Capitalism. The Information Society 26 (3): 176-196.

Fuchs, Christian. 2011. Foundations of Critical Media and Information Studies. New York: Routledge.

Fuchs, Christian. 2012a. Dallas Smythe Today: The Audience Commodity, the Digital Labour Debate, Marxist Political Economy, and Critical Theory. tripleC: Open Access Journal for a Global Sustainable Information Society 10 (2): 692-740.

Fuchs, Christian. 2012b. With or without Marx? With or without Capitalism? A Rejoinder to Adam Arvidsson and Eleanor Colleoni. tripleC: Open Access Journal for a Global Sustainable Information Society 10 (2): 633-645.

Fuchs, Christian. 2014. Social Media. A Critical Introduction. London: Sage.

Fuchs, Christian and Wolfgang Hofkirchner. 2005. Self-Organization, Knowledge, and Responsibility. Kybernetes 34 (1-2): 241-260.

Fuchs, Christian, Wolfgang Hofkirchner, Matthias Schafranek, Celina Raffl, Marisol Sandoval and Robert Bichler. 2010. Theoretical Foundations of the Web: Cognition, Communication, and Cooperation. Towards an Understanding of Web 1.0, 2.0, 3.0. Future Internet 2 (1): 41-59.

Garnham, Nicholas. 1990. Capitalism and Communication. London: Sage.

Garnham, Nicholas. 2000. Emancipation, the Media, and Modernity. Oxford: Oxford University Press.

Gauntlett, David. 2011. Making is Connecting. The Social Meaning of Creativity, from DIY and Knitting to YouTube and Web 2.0. Cambridge: Polity.

Gill, Rosalind. 2002. Cool, Creative and Egalitarian? Exploring Gender in Project-Based New Media Work in Europe. Information, Communication \& Society 5 (1): 70-89.

Gill, Rosalind. 2006. Technobohemians or the New Cybertariat? Amsterdam: Institute of Network Cultures.

Gorz, André. 1982. Farewell to the Working Class. An Essay on Post-Industrial Socialism. London: Pluto Press.

Habermas, Jürgen. 1969. Technik und Wissenschaft als "Ideologie". Frankfurt am Main: Suhrkamp.

Habermas, Jürgen. 1984. The Theory of Communicative Action. Volume 1. Boston, MA: Beacon Press.

Habermas, Jürgen. 1987. The Theory of Communicative Action. Volume 1. Boston, MA: Beacon Press.

Hampton, Paul. 2008. William Morris: Romantic or Revolutionary? http://www.workersliberty.org/story/2008/12/04/william-morris-romantic-or-revolutionary

Hardt, Michael. 2010. The Common in Communism. In The Idea of Communism, edited by Costas Douzinas and Slavoj Žižek, 131-144. London: Verso.

Hardt, Michael and Antonio Negri. 2004. Multitude. New York: Penguin.

Harvie, David. 2005. All Labour Produces Value for Capital: And We All Struggle Against Value. The Commoner 10: 132-171. Hegel, Georg Willhelm Friedrich. 1991. The Encyclopaedia Logic. Indianapolis, IN: Hackett.

Hesmondhalgh, David and Sarah Baker. 2011. Creative Labour. Media Work in Three Cultural Industries. London: Routledge.

Hofkirchner, Wolfgang. 2002. Projekt Eine Welt: Kognition - Kommunikation - Kooperation. Münster: LIT.

Holloway, John. 1995. From Scream of Refusal to Scream of Power: The Centrality of Work. In Open Marxism, Volume III: Emancipating Marx, edited by Werner Bonefeld, Richard Gunn, John Holloway and Kosmas Psychopedis, 155-181. London: Pluto Press.

Hund, Wulf D. 1976. Ware Nachricht und Informationsfetisch. Zur Theorie der gesellschaftlichen Kommunikation. Darmstadt: Luchterhand.

Hund, Wulf D. and Bärbel Kirchhoff-Hund 1980. Soziologie der Kommunikation. Arbeitsbuch zu Struktur und Funktion der Medien. Grundbegriffe und exemplarische Analysen. Hamburg: Rowohlt.

Huws, Ursula. 1999/2003. Material World: The Myth of the Weightless Economy. In The Making of the Cypertariat: Virtual Work in a Real World, 126-151. New York: Monthly Review Press.

Huws, Ursula. 2010. Expression and Expropriation: The Dialectics of Autonomy and Control in Creative Labour. Ephemera: Theory \& Politics in Organization 10 (3/4): 504-521.

Jenkins, Henry. 2006. Convergence culture. New York: New York University Press. 
Jeon, Heesang. 2010. Cognitive Capitalism or Cognition in Capitalism? A Critique of Cognitive Capitalism Theory. Spectrum: Journal of Global Studies 2 (3): 89-116.

Jhally, Sut and Bill Livant. 1986/2006. Watching as Working. The Valorization of Audience Consciousness. In The Spectacle of Accumulation. Essays in Culture, Media, \& Politics, 24-43. New York: Peter Lang.

Lazzarato, Maurizio. 1996. Immaterial Labour. In Radical Thought in Italy, ed. Paolo Virno and Michael Hardt, 133-146. Minneapolis, MN: University of Minnesota Press.

Lenin, Vladimir I. 1917. State and Revolution. In Essential Works of Lenin, 271-364. New York: Dover.

Leontjew, Alexei Nikolajewitsch. 1978. Activity, Consciousness, and Personality. http://www.marxists.org/archive/leontev/works/1978/index.htm

Linebaugh, Peter. 2011. Foreword to the 2011 Edition. In William Morris: Romantic to Revolutionary, Edward P. Thompson, vii-xliii. Pontypool: The Merlin Press. Reprinted with a New Foreword.

Marcuse, Herbert. 1941. Some Social Implications of Modern Technology. In Technology, War and Fascism: Collected Papers of Herbert Marcuse, Volume 1, edited by Douglas Kellner, 41-65. London: Routledge.

Marcuse, Herbert. 1955. Eros and Civilization. Boston, MA: Beacon Press.

Marcuse, Herbert. 1958. Soviet Marxism. A Critical Analysis. New York: Columbia University Press.

Marcuse, Herbert . 1964. One-Dimensional Man. Studies in the Ideology of Advanced Industrial Society. London: Routledge.

Marcuse, Herbert. 1965. Remarks on a Redefinition of Culture. In The Essential Marcuse. Selected Writings of Philosopher and Social Critic Herbert Marcuse, edited by Andrew Feenberg and William Leiss, 13-31. Boston, MA: Beacon Press.

Marcuse, Herbert. 1967a. Art in the One-Dimensional Society. In Art and Liberation: Collected Papers of Herbert Marcuse, Volume 4, edited by Douglas Kellner, 113-122. London: Routledge.

Marcuse Herbert. 1967b. Society as a Work of Art. In Art and Liberation: Collected Papers of Herbert Marcuse, Volume 4, edited by Douglas Kellner, 123-129. London: Routledge.

Marcuse, Herbert. 1979. Children of Prometheus: 25 Theses on Technology and Society. In Philosophy, Psychoanalysis and Emancipation. Collected papers of Herbert Marcuse, Volume 5, 222-225. London: Routledge.

Marx, Karl. 1844. Economic and Philosophic Manuscripts of 1844. Mineola, NY: Dover. [German edition: Ökonomisch-philosophische Manuskripte. In Marx Engels Werke, 465-588. Berlin: Dietz].

Marx, Karl. 1857/58a. Grundrisse der Kritik der politischen Ökonomie. MEW, Band 42. Berlin: Dietz.

Marx, Karl. 1857/58b. Grundrisse. London: Penguin.

Marx, Karl. 1859. A Contribution to the Critique of Political Economy. http://www.marxists.org/archive/marx/works/1859/critique-pol-economy/index.htm

Marx, Karl. 1861-63. Economic Manuscripts of 1861-1863. http://www.marxists.org/archive/marx/works/1861/economic/index.htm

Marx, Karl. 1865. Value, Price, and Profit. http://www.marxists.org/archive/marx/works/1865/valueprice-profit/index.htm

Marx, Karl. 1867. Capital: A Critique of Political Economy: Volume One. London: Penguin.

Marx, Karl. 1875. Critique of the Gotha Programme. http://www.marxists.org/archive/marx/works/1875/gotha/index.htm

Marx, Karl. 1894. Capital: A Critique of Political Economy: Volume Three. London: Penguin.

Marx, Karl and Friedrich Engels (MEW). 1968ff. Marx Engels Werke. Berlin: Dietz.

Marx, Karl and Friedrich Engels. 1845/46. The German Ideology. Amherst, NY: Prometheus Books.

Mezzadra, Sandro, and Andrea Fumagalli, ed. 2010. Crisis in the Global Economy: Financial Markets, Social Struggles, and New Political Scenarios. Los Angeles: Semiotext(e).

Mies, Maria, Veronika Bennholdt-Thomsen and Claudia von Werlhof. 1988. Women: The Last Colony. London: Zed Books.

Morris, William. 1884a. A Factory As It Might Be I. Justice, May 17. http://www.marxists.org/archive/morris/works/1884/justice/10fact1.htm

Morris, William. 1884b. Useful Work Versus Useless Toil. In The Collected Works of William Morris. Volume 23: Signs of Changes: Lectures on Socialism, 98-120. Cambridge: Cambridge University Press.

Morris, William. 1884c. Work in a Factory As It Might Be III. Justice, June 28: 2. http://www.marxists.org/archive/morris/works/1884/justice/13fact3.htm 
Morris, William. 1885. How We Live and How We Might Live. In The Collected Works of William Morris. Volume 23: Signs of Changes: Lectures on Socialism, 3-26. Cambridge: Cambridge University Press.

Morris, William. 1893. Communism. In The Collected Works of William Morris. Volume 23: Signs of Changes: Lectures on Socialism, 264-276. Cambridge: Cambridge University Press.

Morris, William. 1894. How I Became a Socialist. In The Collected Works of William Morris. Volume 23: Signs of Changes: Lectures on Socialism, 277-281. Cambridge: Cambridge University Press.

Mosco, Vincent. 2011. Communication and Cultural Labour. In The Renewal of Cultural Studies, edited by Paul Smith, 230-237. Philadelphia, PA: Temple University Press.

Negri, Antonio. 1971/1988. Crisis of the Planner-State. Communism and Revolutionary Organisation. In Revolution Retrieved. Selected Writings on Marx, Keynes, Capitalist Crisis \& New Social Subjects 1967-83, 91-148. London: Red Notes.

Negri, Antonio. 1979/1988. Marx beyond Marx. Working Notebooks on the Grundrisse. In Revolution Retrieved. Selected Writings on Marx, Keynes, Capitalist Crisis \& New Social Subjects 1967-83, 149-176. London: Red Notes.

Negri, Antonio. 1982/1988. Archaeology and Project. The Mass Worker and the Social Worker. In Revolution Retrieved. Selected Writings on Marx, Keynes, Capitalist Crisis \& New Social Subjects 1967-83, 199-228. London: Red Notes.

Negri, Antonio. 1991. Marx beyond Marx. Lessons on the Grundrisse. New York: Autonomedia.

Scholz, Trebor, ed. 2012. Digital Labour. The Internet as Playground and Factory. New York: Routledge.

Sevignani, Sebastian. 2012. The Problem of Privacy in Capitalism and the Alternative Social Networking Site Diaspora*. tripleC: Open Access Journal for a Global Sustainable Information Society 10 (2): 600-617.

Smythe, Dallas W. 1977. Communications: Blindspot of Western Marxism. Canadian Journal of Political and Social Theory 1 (3): 1-27.

Smythe, Dallas W. 1981. The Audience Commodity and its Work. In Dependency Road. Communications, Capitalism, Consciousness, and Canada, 22-51. Norwood, NJ: Ablex.

Stalin, Josef V. 1938. Dialectical and Historical Materialism.

http://www.marx2mao.com/Stalin/DHM38.html

Thompson, Edward P. 1994. Persons \& Polemics. Historical Essays. London: Merlin Press.

Thompson, Edward P. 2011. William Morris: Romantic to Revolutionary. Pontypool: The Merlin Press. Reprinted with a New Foreword.

Vercellone, Carlo. 2007. From Formal Subsumption to General Intellect: Elements for a Marxist Reading of the Thesis of Cognitive Capitalism. Historical Materialism 15 (1): 13-36.

Vercellone, Carlo. 2010. The Crisis of the Law of Value and the Becoming-rent of the Profit. In Crisis in the Global Economy: Financial Markets, Social Struggles, and New Political Scenarios, edited by Sandro Mezzadra and Andrea Fumagalli, 85-119. Los Angeles: Semiotext(e).

Weeks, Kathi. 2011. The Problem with Work. Feminism, Marxism, Antiwork Politics and Postwork Imaginaries. Durham, NC: Duke University Press.

Weingart, Brigitte. 1997. Arbeit - ein Wort mit langer Geschichte. http://www.ethikprojekte.ch/texte/arbeit.htm

Williams, Raymond. 1980. Culture and Materialism. London: Verso.

Williams, Raymond. 1983. Keywords. New York: Oxford University Press.

Special Eurobarometer 359. Attitudes on Data Protection and Electronic Identity in the European Union. http://ec.europa.eu/public_opinion/archives/ebs/ebs_359 en.pdf

Žižek, Slavoj. 2010. How to Begin from the Beginning. In The Idea of Communism, edited by Costas Douzinas and Slavoj Žižek, 209-226. London: Verso.

\section{About the Authors}

Christian Fuchs

is professor at the University of Westminster's Communication and Media Research Institute and the editor of tripleC: Communication, Capitalism \& Critique: Open Access Journal for a Global Sustainable Information Society, chair of the European Sociological Association's Research Network 18 - Sociology of Communications and Media Research, co-founder of the ICTs and Society Network and board member of the UTI Research Group in Austria.

Sebastian Sevignani

CC: Creative Commons License, 2013. 
is member of the Unified Theory of Information (UTI) Research Group, doctoral student at the University of Salzburg and research associate in the project "Social networking sites in the surveillance society" (http://sns3.uti.at, funded by the Austrian Science Fund). His dissertation focuses on the analysis of privacy in capitalism and the role that social media play in this context. 